
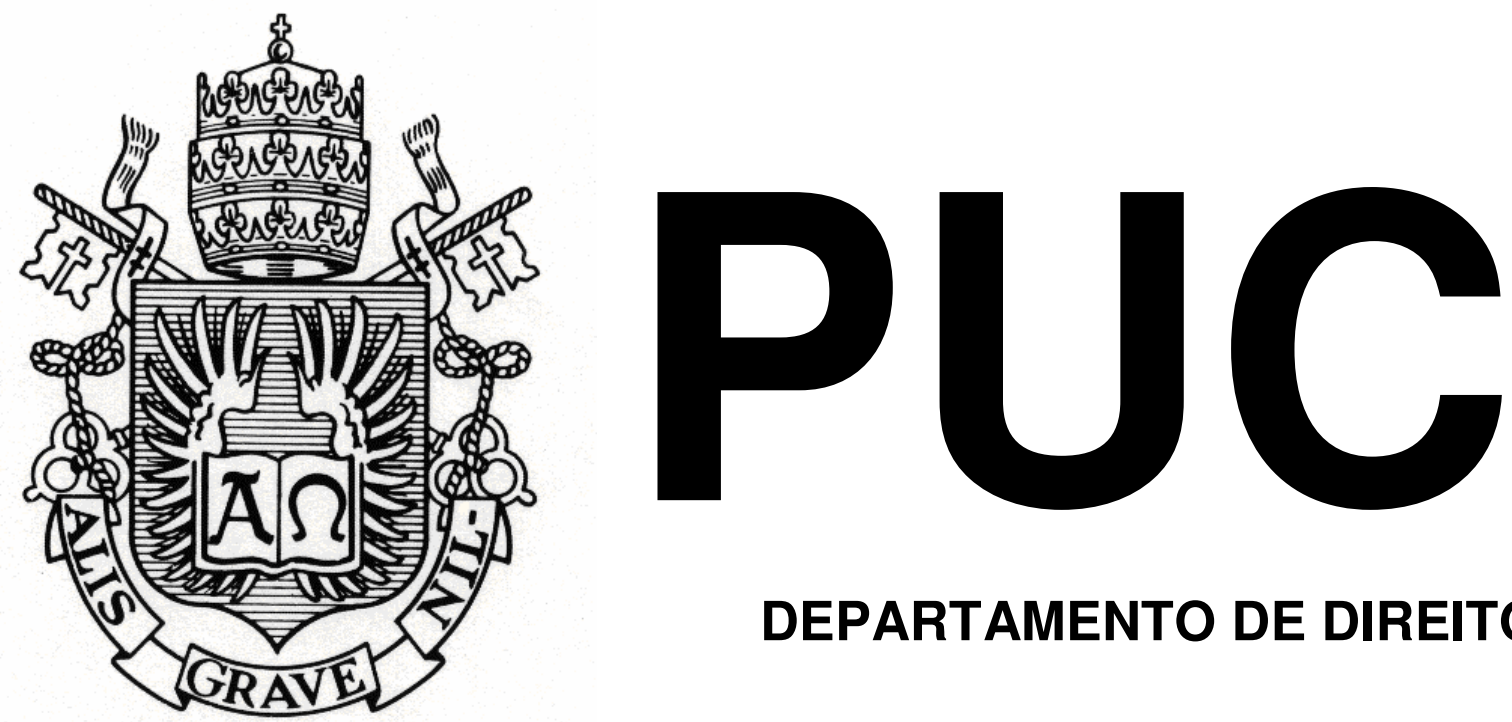

DEPARTAMENTO DE DIREITO

\title{
O VALOR DA PROVA COLHIDA NO INQUÉRITO POLICIAL À LUZ DO SISTEMA ACUSATÓRIO
}

por

CAMILA GONÇALVES DE SOUZA VILELA

ORIENTADOR: DIOGO RUDGE MALAN

2009.1

PONTIFÍCIA UNIVERSIDADE CATÓLICA DO RIO DE JANEIRO

RUA MARQUÊS DE SÃO VICENTE, 225 - CEP 22453-900

RIO DE JANEIRO - BRASIL 


\section{O VALOR DA PROVA COLHIDA NO INQUÉRITO POLICIAL À LUZ DO SISTEMA ACUSATÓRIO}

por

\section{CAMILA GONÇALVES DE SOUZA VILELA}

Monografia apresentada ao Departamento de Direito da Pontifícia Universidade Católica do Rio de Janeiro (PUC-Rio) como requisito parcial para a obtenção do Título de Bacharel em Direito.

Orientadora: Diogo Rudge Malan

2009.1 


\section{Agradecimento}

Aos meus pais, João Luiz e Sônia,

pelo apoio incondicional, todo o meu

amor e respeito.

Ao meu irmão José Vitor,

toda a minha admiração por

seu caráter e apoio nos momentos

mais difíceis.

Aos meus amigos, Amanda de Andrade,

Danielle Meireles, Karoll Macedo, Felipe Miranda,

Jorge Babur, Nathália Rodrigues e Luciana Marcondes,

obrigado pelo carinho e pelos conselhos.

Ao meu orientador, Diogo Malan, minha admiração

Pelo profissional e reconhecimento pela

inestimável dedicação à minha monografia. 


\section{RESUMO}

A presente obra monográfica tem como escopo a análise da valoração dos elementos informativos colhidos no inquérito policial à luz de um sistema acusatório. Para essa possível análise, é preciso observar o histórico dos sistemas processuais desde o processo penal romano e as mudanças pelas quais a história do processo penal moderno vem passando. A evolução dos sistemas processuais ao longo da história demonstra que a assimilação das características dos sistemas vem tomando contornos diferentes, mas sempre tentando se equilibrar entre os princípios fundamentais do devido processo legal e a eficácia no controle da criminalidade.

No decorrer da presente obra, serão demonstradas as compatibilidades e as dissonâncias entre os princípios postulados na Constituição da República de 1988 e as normas da legislação ordinária, o então Código de Processo Penal de 1941, que se encontra já superado pela doutrina. A importância na delimitação do sistema processual penal vai ensejar um movimento por reformas de um já superado Código de Processo Penal no sentido de adequá-lo aos preceitos de uma Constituição de um Estado Democrático de Direito. 


\section{Lista de abreviaturas}

abr. - abril

Art. -artigo

Arts.- artigos

Bol.IBCCrim - Boletim do Instituto Brasileiro de Ciências Criminais

CF/88 - Constituição Federal de 1988

$\mathrm{CP}$ - Código Penal

CPP - Código de Processo Penal

CPP/41 - Código de Processo Penal de 1941

CR/88 - Constituição da República de 1988

DJ - Diário de Justiça

DOU - Diário Oficial da União

Ed. -edição

HC - Habeas Corpus

Inc. - inciso

Jan. - janeiro

jun. - junho

Mar. - março

MP - Ministério Público

n. - número

OAB - Ordem dos Advogados do Brasil

p. - página

PL- Projeto de lei

PLS - Projeto de lei no Senado

PR -Paraná

Rel. Min. - Relator Ministro

RJ - Rio de Janeiro

RMS - Recurso em Mandado de Segurança

STF - Supremo Tribunal Federal

STJ - Superior Tribunal de Justiça

USP - Universidade de São Paulo

Vol. - volume 


\section{Sumário}

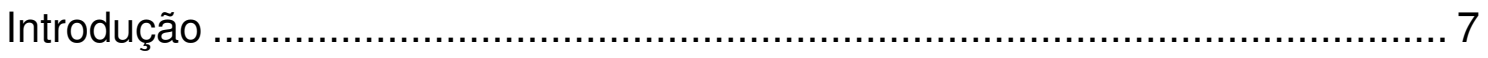

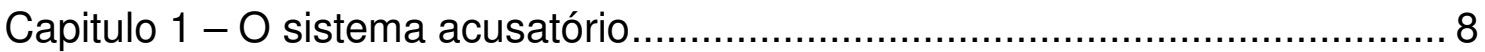

1.1. Histórico dos sistemas processuais penais ........................................... 8

1.1.1. O estudo do contexto histórico dos sistemas ...................................... 8

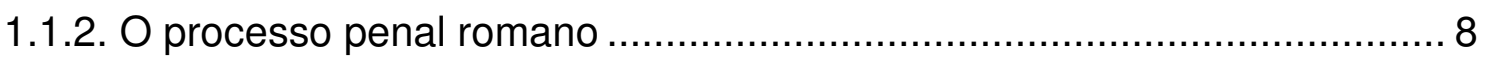

1.1.3.A influência do Direito canônico no processo penal romano .................... 10

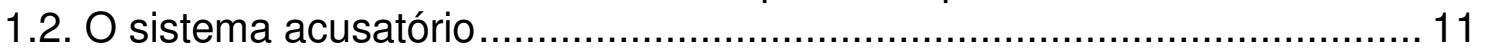

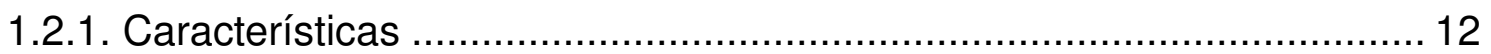

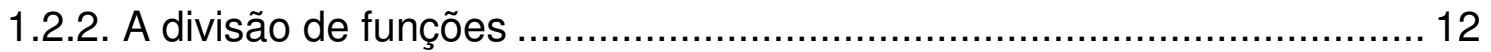

1.2.3. O acusado como sujeito de direitos ................................................. 14

1.2.4. Oralidade e publicidade................................................................... 16

1.3. Sistema acusatório na Constituição da República de 1988....................... 18

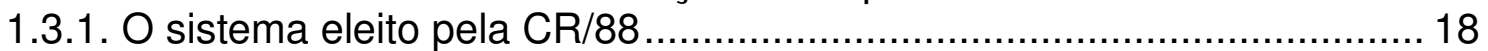

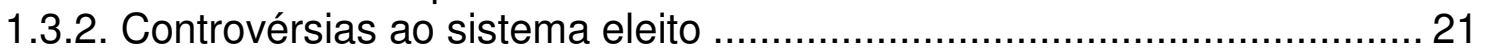

1.3.3. Sistema acusatório e poderes instrutórios do juiz ................................ 22

1.4. O sistema acusatório da $\mathrm{CR} / 88$ e o $\mathrm{CPP} / 41$............................................ 24

1.4.1. O juiz e a instauração do inquérito policial ex officio .............................. 24

1.4.2. O juiz e a gestão de provas ................................................................. 25

1.4.3. A imparcialidade e o controle dos elementos de informação ................. 26

1.4.4. O Ministério Público e sua independência.......................................... 27

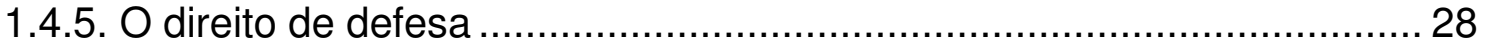

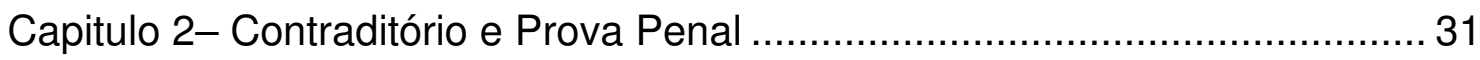

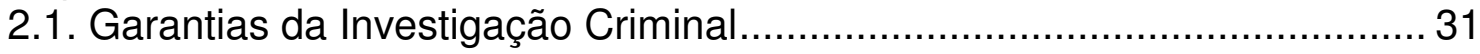

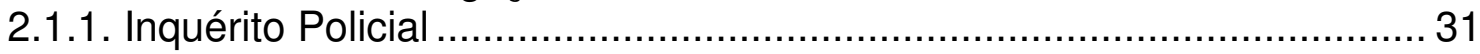

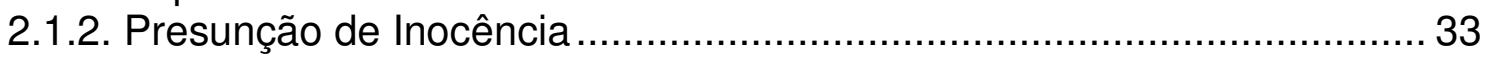

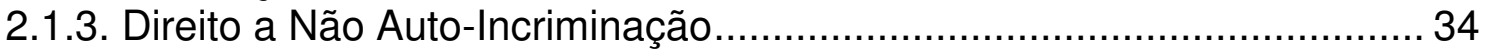

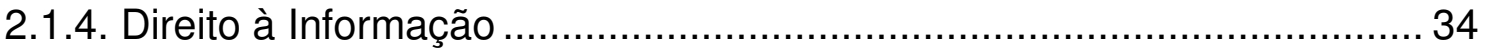

2.1.5. Investigação e Publicidade externa ....................................................... 35

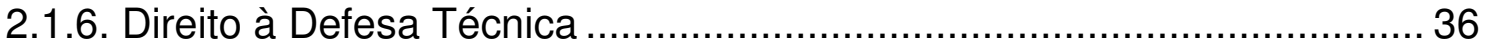

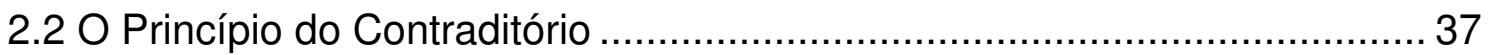

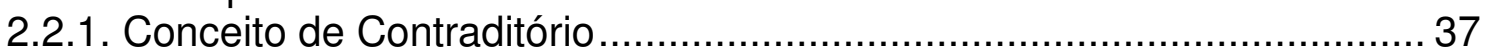

2.2.2. Contraditório e Investigação Preliminar................................................ 39

2.2.3. Contraditório e Prova Penal .............................................................. 41

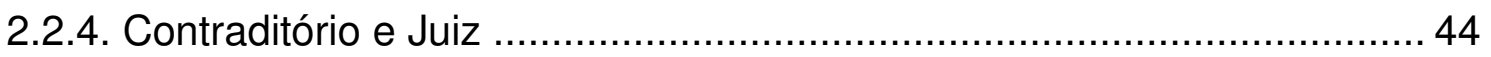

2.3 Provas Colhidas no Inquérito Policial ..................................................... 46

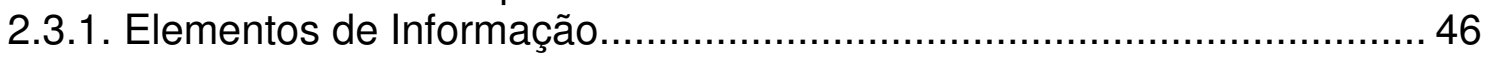

2.3.2. Produção Antecipada de Provas ..................................................... 47

2.4. Críticas ao Modelo Atual ................................................................... 49

2.4.1. Ausência de um Juiz exclusivo para a Investigação .............................. 49

2.4.2. Influência da Fase Investigativa na Judicial ........................................ 50

Capítulo 3 - A Reforma do Código de Processo Penal.................................... 51

3.1. Código Modelo de Processo Penal para Ibero - América........................... 51

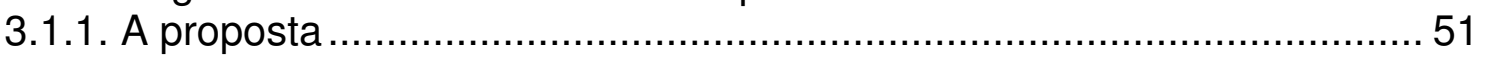


3.1.2. A disciplina das provas no Código Modelo ...........................................52

3.2. A Reforma do Código de Processo Penal ............................................... 53

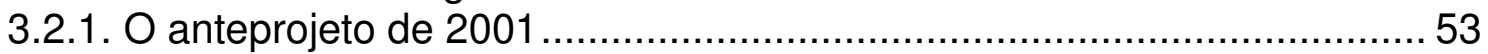

3.2.2. O anteprojeto na disciplina das provas................................................ 54

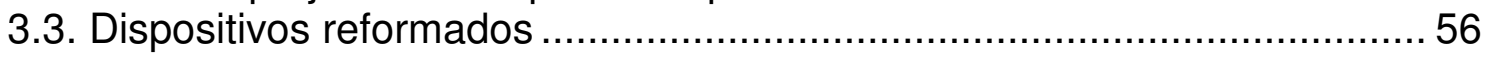

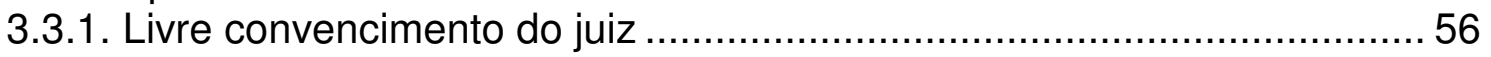

3.3.2. A utilização dos elementos informativos na sentença ............................ 57

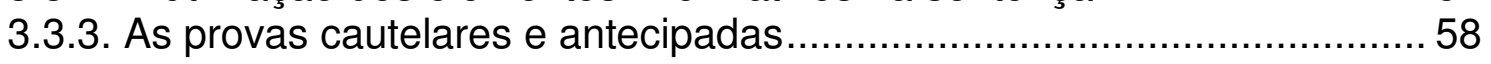

3.3.4. Provas "não repetíveis" ..................................................................... 59

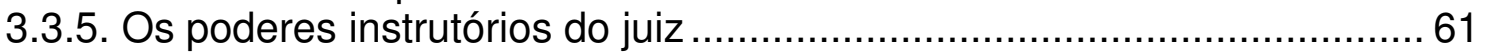

3.3.6. A prova pericial e o contraditório ...................................................... 63

3.3.7. A alteração quanto ao número de peritos e a figura do assistente técnico

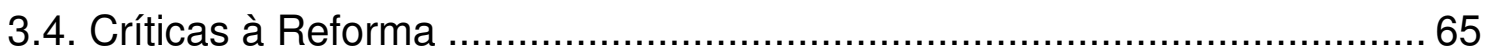

3.5. O PLS no. 156/2009 do novo Código de Processo Penal........................... 67

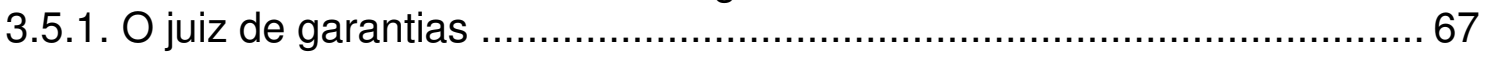

3.5.2. Os elementos de informação do Inquérito Policial .................................. 68

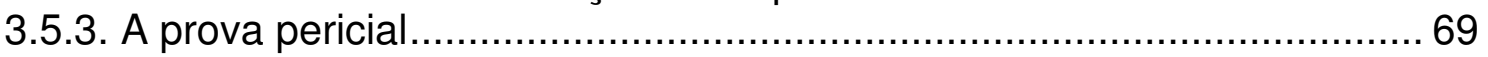

3.6. A melhor opção de Código de Processo Penal ....................................... 70

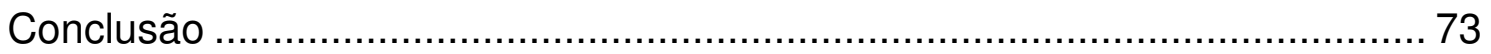

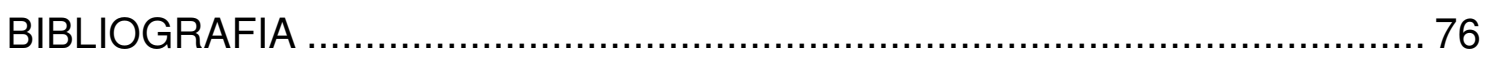




\section{Introdução}

Na busca pela delimitação da valoração da prova colhida no inquérito policial e sua utilização pelo magistrado na fundamentação da sentença penal condenatório, será preciso fazer uma breve análise histórica dos sistemas processuais penais, desde o sistema de processo penal romano até os dias de hoje, em um Estado Democrático de Direito.

É necessário delimitar as características do sistema processual penal de cunho acusatório e assim, verificar a dinâmica dos sujeitos presentes no cenário da relação jurídica processual para que possamos concluir qual a relação encontrada entre a Constituição Federal de 1988 e o Código de Processo Penal de 1941.

A análise sobre as características do sistema acusatório recairá, sobretudo, aos postulados constitucionais da separação de poderes e dos direitos e garantias fundamentais do indivíduo, típicos de um modelo de Estado garantista, como o Brasil.

Ao longo da obra, a grande discussão também recairá sobre a prova penal e o princípio do contraditório, condição necessária para balizar os limites do valor encontrado nos elementos de informação colhidos na investigação preliminar. Importante também será fixar as funções desses elementos trazidas pela doutrina brasileira e pela jurisprudência a qual desempenhou grande papel na historia do processo penal.

Por fim, a análise recairá na recente reforma do Código de Processo Penal de 1941 que modificou alguns temas, sobretudo, o tema das provas, dando origem à Lei n. 11.690/08. O estudo da reforma abrange o exame que foi feito pela Comissão responsável pelo anteprojeto do Código de Processo Penal do postulados de um sistema acusatório e do Código Modelo de Processo Penal para Ibero - América. 


\section{Capitulo 1 - 0 sistema acusatório}

\subsection{Histórico dos sistemas processuais penais}

\subsubsection{O estudo do contexto histórico dos sistemas}

O estudo das origens históricas dos sistemas processuais penais é fundamental para delimitar as características de cada um dos sistemas, já que a doutrina, hoje, não concebe sistemas puros, tanto de sistema acusatório, quanto de um modelo inquisitivo. A não existência de modelos puros, na atualidade, cria sistemas mistos e complica a definição perfeita de um modelo e de outro. Por isso, a sua análise histórica é essencial até mesmo para criar parâmetros normativos e fundamentar políticas criminais.

A partir do estudo do contexto evolutivo e histórico, será possível analisar o surgimento das estruturas do Sistema Acusatório, as mudanças quanto aos procedimentos considerados inquisitórios na Civilização Ocidental e o entendimento quanto aos atuais sistemas nas sociedades. A definição destes procedimentos e das características dos sistemas processuais vai ser influenciada, sobretudo, pela posição dos sujeitos inseridos no processo, o modo como atuam e a ligação da atuação jurisdicional das partes processuais com as provas ${ }^{1}$.

\subsubsection{O processo penal romano}

A análise recai sobre o modelo que mais influência destinou aos sistemas processuais de diversos países e principalmente, no caso do Brasil, ao Tribunal do Júri². O modelo sob análise é o processo penal romano em sua segunda fase, a acusatória, muito semelhante ao direito ateniense ${ }^{3}$.

\footnotetext{
${ }^{1}$ PRADO, Geraldo. Sistema acusatório: a conformidade constitucional das leis processuais penais. $4^{\mathrm{a}}$ ed. Rio de Janeiro: Lumen Juris, 2006. 61-69 p.

2 "Até hoje, no procedimento do sobredito Tribunal, adota-se procedimento similar àquele das questiones perpetuae, notadamente quanto À: (i) forma de recrutamento dos jurados: cidadãos de notória idoneidade, cujos nomes constam de lista anualmente confeccionada pelo juiz-presidente
} 
O Estado Romano sentiu a necessidade de criar formas mais eficientes de persecução penal devido a sua expansão territorial pela Itália, exercendo sua hegemonia através do controle dos povos e da organização das colônias conquistadas ${ }^{4}$. No Estado Romano, a lei escrita ${ }^{5}$ - Lei das XII Tábuas que abarcava normas de direito público e privado - também foi fator de extrema importância, pois gerava segurança no direito aplicado e evitava o arbítrio dos magistrados. A lei escrita permitia ao juiz declarar o direito, previamente estabelecido, às partes da relação jurídica com critérios de equidade e legalidade.

A acusação, também com poderes de fiscalização das investigações, era realizada por qualquer cidadão do Estado Romano no interesse da sociedade, com exceção dos incapazes e dos indignos, devendo ser requerida ao juiz. Assim, após a requisição pela acusação, o magistrado poderia recebê-la ou não e, caso fosse recebida, iniciava-se a acusação formal e a citação era feita ao acusado.

O procedimento se realizava, sobretudo, em uma estrutura dialética contraditória da produção de provas, oral e pública. Desse modo, esta estrutura permitia a participação efetiva das partes no processo ${ }^{6}$.

(CPP, ARTS. 436, 439, 440 e 441); (ii) denominação dos componentes do órgão judicante popular: jurados (CPP, art. 433); (iii) formação do órgão judicante mediante sorteio (CPP, arts. 427, 428 e 429); (iv) recusa de certo número de sorteados, sem necessidade de motivação (CPP, art. $459, \S 2^{\circ}$ ); (v) prestação de juramento por parte dos jurados (CPP, art. 464); (vi) metodologia de votação, mediante resposta simples e objetiva: sim ou não (CPP, art. 485); (vii) decisão tomada por maioria de votos (CPP, art. 488); (viii) soberania dos veredictos (CR/88, ART. 5, XXXVIII, c); (ix) atribuição do juiz-presidente (CPP, art. 497); (x) indispensabilidade de comparecimento do acusado para realização do julgamento (CPP, ART. 449)". SAAD, Marta; MALAN, Diogo Rudge. Origens históricas dos sistemas acusatório e inquisitivo, In: Revista dos Tribunais, São Paulo, Vol. 842, Ano 94. 2005. 421p.

${ }^{3} \mathrm{Na}$ Grécia Antiga, o Direito Ateniense dividiu os delitos em duas classes: públicos e privados, onde o primeiro dava ensejo à acusação popular concedida a um cidadão para representar o próprio povo, como expressão da sua soberania. O processo era público e oral, na presença do contraditório e havia igualdade entre acusador e acusado, mas admitia-se a tortura e dos juízos de Deus como forma de construção probatória, a valoração da prova segundo a íntima convicção do juiz e a decisão judicial era irrecorrível. PRADO, Geraldo. Op. cit., 773-74 p.

${ }^{4}$ ALVES, José Carlos Moreira. Direito Romano. 13 ${ }^{\mathrm{a}}$ ed. Rio de Janeiro: Editora Forense, 2003. 20-21 p.

${ }^{5}$ A Lei das XII Tábuas estabelecia o predomínio da intervenção do Estado na esfera das liberdades individuais para conter os danos à sociedade e à vítima e conceder uma acusação ao acusado nos limites da regularidade legal, incluindo deveres e direitos. GIORDANI, Mário Curtis. Direito penal romano. $3^{\mathrm{a}}$ ed. Rio de Janeiro. Lumen Juris, 1997. 95 p.

${ }^{6}$ Ibidem, 101-105 p. 
Os órgãos definitivos e previamente definidos em lei eram capazes de investigar e julgar as matérias penais, sendo que o mesmo órgão que acusava não era o que julgava. Os que julgavam eram chamados quaestiones perpetuae e dotados de técnica jurídica e autonomia, mas observavam o principio do nemo in iudicium tradetur sine accusatione (ninguém pode ser levado a juízo sem uma acusação).

$\mathrm{O}$ acusado se encontrava em posição de sujeito de direitos e garantias individuais, como por exemplo, o direito de fiscalizar as investigações realizadas sobre ele ${ }^{7}$. Porém, após a República, iniciado o período do Império, se verificou o aumento das atribuições do juiz e com isso, muitos casos de impunidade, deturpação da verdade e procedimentos realizados de oficio. A influência do cristianismo e suas práticas inquistorialistas durante o processo foi fundamental para a reforma do sistema penal ${ }^{8}$.

\subsubsection{A influência do Direito canônico no processo penal romano}

Em decorrência da formação da sociedade feudal que se destacou em relação ao poder do rei e se fortaleceu em virtude da estrutura social e econômica dos feudos, a influência da Jurisdição Eclesiástica (antes somente responsável por julgar os conflitos entre os membros da Igreja) foi determinante nos conflitos dessa sociedade.

Em 1215, foi instituída a Inquisição pelo Papa Inocêncio III que determinou diversas práticas inquisitorialistas, entre elas, a tortura e a busca pela verdade real contra àqueles que pudessem ser contrários aos desmandos da Igreja ${ }^{9}$. O argumento era coibir a heresia e a usura e, assim, salvar a alma daquele "pecador" que se declarava contra os dogmas da Igreja.

\footnotetext{
${ }^{7}$ ALVES, José Carlos Moreira. Op. cit., 181-192 p.

${ }^{8}$ SAAD, Marta; MALAN, Diogo Rudge. Op. cit., 413-421p.

${ }^{9}$ PRADO, Geraldo. Op. cit., 78-88 p.
} 
Em primeiro lugar, os processos eram instaurados sem uma acusação propriamente dita, inclusive, admitindo-se as denúncias anônimas infundadas para tanto. O acusado era presumido culpado e perdia a condição de sujeito de direitos e garantias individuais dada pelo Direito Romano das quaestiones perpetuae. Passa, então, à condição de mero objeto de investigação e de acusação.

Em seguida, a investigação secreta e a acusação de ofício eram realizadas por um juiz nomeado pelo Papa, dotado de amplos poderes instrutórios e decisórios que podia, inclusive, dispensar provas da defesa.

O procedimento do Tribunal do Santo Ofício era escrito, secreto e estabelecia uma organização prévia de valorização de provas (hierarquia de provas). O debate oral e o contraditório eram diferidos ou quase inexistentes. $\mathrm{Na}$ fase de instrução, os indícios colhidos durante a investigação possuíam tanto valor quanto as provas produzidas em juízo, admitindo-se, inclusive, a falta de confissão do acusado e o seu não comparecimento na audiência como provas fundamentais à condenação do réu.

A tortura era prática formalmente utilizada para justificar a falta de provas possíveis à condenação e/ou quando a autoria fosse provável. Ao final, como não havia separação de funções, o mesmo juiz que investigava e acusava era competente para julgar e decidir o caso conforme sua livre e arbitrária convicção ${ }^{10}$.

\subsection{O sistema acusatório}

A definição de sistema acusatório propriamente dito é bem clara na concepção de FERRAJOLI ${ }^{11}$. Segundo o doutrinador:

"se pode chamar acusatório a todo sistema processual que concebe o juiz como um sujeito passivo rigidamente separado das partes e o juízo como uma contenda entre iguais iniciada pela acusação, a quem compete o ônus da prova, enfrentada

\footnotetext{
${ }^{10}$ SAAD, Marta; MALAN, Diogo Rudge. Op. cit., 421-431 p. Nesse item os autores determinam as características do processo penal canônico e o sistema da inquisição.

${ }^{11}$ FERRAJOLI, Derecho y Razón, 564 p. In: PRADO, Geraldo. Op. cit., 153 p.
} 
a defesa em um juízo contraditório, oral e público e resolvida pelo juiz segundo sua livre convicção".

\subsubsection{Características}

O sistema acusatório ${ }^{12}$ compreende o conjunto de normas e princípios fundamentais do devido processo legal orientado por um princípio supremo, o princípio acusatório, corolário de um conjunto de princípios e garantias que tem como ponto de partida a proteção do indivíduo ${ }^{13}$ e sua presunção de inocência.

\subsubsection{A divisão de funções}

A separação das funções de acusar e julgar são inerentes ao devido processo legal do sistema acusatório e exige a existência de um órgão independente para cada atuação. É imprescindível analisar o modo como estes órgãos atuam e desempenham suas tarefas dentro do processo para delimitar o modelo de sistema processual penal. Quem julga não pode acusar, quem acusa não pode julgar, o devido processo penal estabelece esses limites funcionais que são indispensáveis à garantia da existência do sistema acusatório ${ }^{14}$.

\section{Conforme diz FREDERICO MARQUES ${ }^{15}$ :}

“(...) o acusatório traduz a regra de que a descoberta da verdade se opera através do exercício de funções específicas e distintas, dos órgãos fundamentais do processo. O que define e caracteriza a forma acusatória, como resultado do princípio homônimo, é a existência real, segundo FLORIAN, das três funções

\footnotetext{
${ }^{12}$ Giovanni Leone diz que a origem do sistema acusatório se vincula a uma concepção democrática, tanto é assim, que foi adotado por antigos regimes democráticos e republicanos. $\mathrm{O}$ processo acusatório tem como causa natural e imediata de que em uma democracia a autoridade soberana está em todos os membros da organização política. LEONE, Giovanni. Tratado de Derecho Procesal Penal. Traduzido por Santiago Sentis Melendo. Buenos Aires: Ediciones Jurídicas Europa-America, 193, 23 p. In: BASTOS, Marcelo Lessa. A investigação nos crimes de ação penal de iniciativa pública: papel do Ministério público; uma abordagem à luz do sistema acusatório e do garantismo. Rio de Janeiro: Lumen Juris, 2004.

${ }^{13}$ A doutrina afirma que não existe mais um sistema puro, portanto, é necessário identificar o princípio que orienta cada um dos sistemas, para conceituar se um sistema processual é acusatório ou inquisitivo. LOPES JUNIOR, Aury. Introdução crítica ao processo penal (fundamentos da instrumentalidade constitucional). $4^{\mathrm{a}}$ ed. Rio de Janeiro: Lumen Juris, 2006. 161-162 p.

${ }^{14}$ BASTOS, Marcelo Lessa. Op. cit., 43 p.

${ }^{15}$ MARQUES, José Frederico. Do Processo Penal Acusatório. In: Estudos de direito processual penal. Rio de Janeiro: Forense. 1960. 21-22 p.
} 
essenciais e básicas do processo: a função de acusar, a de defender e a de julgar. Onde os órgãos dessas atividades fundamentais são distintos e independentes, há um processo de partes, de forma acusatória".

Para tanto, a separação de poderes vai permitir que a sentença jurisdicional seja imparcialmente julgada dentro de limites legais e a acusação esteja ajustada à realização da Justiça. O magistrado na sua função de julgar não é parte do conflito ${ }^{16}$ e o réu tem o direito fundamental de ser acusado e julgado por órgãos estatais imparciais no alcance de suas atribuições $^{17}$.

É indispensável para a escolha da melhor decisão judicial, que o juiz mantenha uma posição neutra de autoritarismo e poder, seja imparcial ${ }^{18} \mathrm{e}$ impessoal na relação de oposição entre acusação e defesa. As partes devem estar em condições de igualdade e a imparcialidade do juiz deve transmitir ao devido processo legal a segurança pertinente como sua própria condição de validade e eficiência ${ }^{19}$.

O magistrado deverá ficar afastado da etapa de investigação preliminar para preservar o próprio equilíbrio da relação entre as partes e para que o direito ao estado de inocência do indivíduo seja efetivamente garantido. Além de suas atribuições de mediação e solução de conflitos levadas a juízo pelas partes, o juiz assume uma postura de garante dos

\footnotetext{
${ }^{16}$ ABADE, Denise Neves. Garantias do processo penal acusatório, In: Garantias do processo penal acusatório: o novo papel do ministério público no processo penal de partes. Rio de Janeiro: Renovar, 2005. 134 p.

17 Por isso, cada órgão público deve exercer suas prerrogativas sob o princípio da indeclinabilidade, ou seja, nem a competência e muito menos a atribuição jurisdicional poderão ser delegadas ou prorrogadas a outros órgãos, pois cabe ao Estado resolver a lide da melhor forma possível, não se esquivando desse dever. COUTINHO, Jacinto Nelson de Miranda. Introdução aos princípios gerais do direito processual penal brasileiro. In: Revista de Estudos Criminais. Porto Alegre, n.1, 2001. 36 p.

${ }^{18}$ A imparcialidade, como falta de envolvimento, tem como pressuposto o princípio do Juiz Natural, porém não tem o mesmo sentido. "Ensina ADA PELLEGRINE GRINOVER que o juiz natural revela-se em dupla garantia: na proibição de juízos extraordinários ex post facto e na não detração ao juiz constitucionalmente competente". GRINOVER, Ada Pellegrini. O processo em sua unidade. Vol. II. Rio de Janeiro: Forense. 1984. 22 p. In: ABADE, Denise Neves. Op. cit., $135-136 \mathrm{p}$.

19 "Com efeito, o juiz que antecipadamente está em condições de ajuizar a solução para o caso penal (que em algumas hipóteses sequer foi objeto de pretensão do interessado), na prática torna dispensável o processo, pois tem definida a questão independentemente das atividades probatórias das partes, comportamentos processuais que devem ser realizados publicamente e em contraditório". PRADO, Geraldo. Op.cit., 107-109 p.
} 
direitos e garantias constitucionais do acusado $^{20}$, assentado em uma estrutura dialética entre acusação e defesa em busca da verdade processual $^{21}$.

Nesse sentido, como condição de eficácia à formação da sua livre convicção, seu exercício deve estar, obrigatoriamente, vinculado à reserva legal de jurisdição, afastado de qualquer manipulação política ou interesse, vinculado à motivação construída em juízo ${ }^{22}$. São circunstâncias de legitimidade do seu poder, sendo a motivação da decisão, em particular, a forma de controle dos direitos individuais e eficácia das provas ${ }^{23}$.

A acusação no sistema acusatório não implica em acusar alguém para aspirar por sua condenação. Antes de qualquer coisa, a acusação é uma função atribuída a um órgão estatal e exercida nos interesses da coletividade. Esta tarefa deve ser exercida por órgão distinto daquele que julga e, além de tudo, só é iniciada após o exercício do direito de ação, por isso vinculada ao princípio da legalidade. Nas palavras de GERALDO PRADO, "protegendo a comunidade das decisões pessoais de cada integrante da referida instituição ${ }^{24, \text {, }}$

A divisão de funções é indispensável à garantia do devido processo legal e de um justo e equilibrado processo, sendo inerente aos direitos e garantias individuais das partes da relação processual.

\subsubsection{O acusado como sujeito de direitos}

\section{Para DENISE NEVES ABADE ${ }^{25}$ :}

“(...) sempre que as medidas processuais que facilitam a aplicação do jus puniendi entrarem em colisão com o jus libertatis, deverão ser ponderados o interesse estatal de persecução penal e os interesses dos cidadãos na manutenção do mais amplo grau de eficácia dos direitos fundamentais".

\footnotetext{
${ }^{20}$ Ibidem, 135-137 p.

${ }^{21}$ O juiz tem a liberdade para guiar a produção de provas trazidas pelas partes no processo e produzidas perante a sua presença, sendo, portanto, a verdade processual àquela produzida em juízo. GOMES FILHO, Antônio Magalhães. O direito à prova no processo penal, 63 p. In: PRADO, Geraldo. Op. cit., 137 P.

${ }^{22}$ LOPES JUNIOR, Aury. Op. cit., 72-78 p.

${ }^{23}$ Ibidem, $263 \mathrm{p}$.

${ }^{24}$ PRADO, Geraldo. Op. cit., 111-113 p.

${ }^{25}$ ABADE, Denise Neves. Op. cit., 128 p.
} 
Antes de tudo, o acusado (ou o indiciado) é presumido inocente de qualquer imputação que lhe é atribuída. AMILTON B. DE CARVALHO ${ }^{26}$ ensina que "o Princípio da Presunção de Inocência não precisa estar positivado em lugar nenhum: é 'pressuposto', nesse momento histórico, da condição humana" de sujeito de direitos e garantias fundamentais. É importante princípio, pois garante uma condição ao acusado de tratamento imparcial do órgão jurisdicional o qual não deve emitir qualquer valoração a priori $^{27}$.

O acusado é sujeito de direitos e deveres e por isso, parte processual na relação dialética acusatória, munido do direito de participar efetivamente do conflito. Contrapondo-se ao direito de ação da acusação, ao acusado the é garantido o direito de defesa no processo e até mesmo em sede de investigações preliminares, mas, antes de tudo, segundo GERALDO PRADO, "a compatibilidade com o princípio acusatório dependerá de a defesa concretamente estar condições de participar em contraditório do processo (...) ${ }^{28, "}$.

O direito de defesa pressupõe que o sujeito passivo e a acusação estejam em paridade de condições e, para tanto, o acusado deve ser assistido por um profissional do ramo do Direito capaz de exercer tecnicamente uma efetiva defesa ${ }^{29}$. Dessa maneira, diz JACINTO NELSON DE MIRANDA COUTINHO ${ }^{30}$ que "a audiência das partes de modo paritário é vital à própria existência do processo, mormente porque expressão, quiçá máxima, do princípio da igualdade".

Importante ressalva faz AURY LOPES JUNIOR ${ }^{31}$ ao citar FOSCHINI:

\footnotetext{
${ }^{26}$ CARVALHO, Amilton Bueno de. "Lei pra que (bem)?". In: Escritos de Direito e Processo Penal, 51 p. In: LOPES JUNIOR, Aury. Op. cit., 185 p.

${ }^{27}$ LOPES JUNIOR, Aury. Op. cit., $186 \mathrm{p}$.

${ }^{28}$ PRADO, Geraldo. Op. cit., 122 p.

${ }^{29}$ LOPES JUNIOR, Aury. Op. cit., 233-234 p.

${ }^{30}$ COUTINHO, Jacinto Nelson de Miranda. Introdução aos princípios gerais do direito processual penal brasileiro. In: Revista de Estudos Criminais. Porto Alegre, n.1, 2001. 44 p.

${ }^{31}$ FOSCHINI, Gaetano. L’Imputato, 26 p. In: LOPES JUNIOR, Aury. Op. cit., 232 p.
} 
"a defesa técnica é considerada indisponível, pois além de ser uma garantia do sujeito passivo, existe um interesse coletivo na correta apuração do fato. Trata-se, ainda, de verdadeira condição de paridade de armas, imprescindível para a concreta atuação do contraditório. Inclusive, fortalece a própria imparcialidade do juiz, pois, quanto mais atuante e eficiente forem ambas as partes, mais alheio ficará o julgador".

\section{Segundo ADA PELLEGRINI GRINOVER ${ }^{32}$ :}

"num determinado enfoque, é inquestionável que é do contraditório que brota a própria defesa. Desdobrando-se o contraditório em dois momentos - a informação e a possibilidade de reação - não há como negar que o conhecimento, ínsito no contraditório, é pressuposto para o exercício da defesa. Mas, de outro ponto de vista, é igualmente válido afirmar que a defesa é que garante o contraditório, conquanto nele se manifesta".

\section{Ensina NELSON NERY JUNIOR ${ }^{33}$ que:}

"como decorrência do princípio da paridade das partes, o contraditório significa dar as mesmas oportunidades para as partes e os mesmos instrumentos processuais para que possam fazer valer os seus direitos e pretensões, ajuizando ação, deduzindo resposta, requerendo e realizando provas, recorrendo das decisões judiciais etc.”.

Logo, a participação das partes deve ser crítica e construtiva em todos os atos do processo, através da produção de provas e na interferência quanto às alegações da outra parte, justamente para que essa participação colabore na formação do espírito e no livre convencimento do magistrado. ${ }^{34}$

\subsubsection{Oralidade e publicidade}

A oralidade é a forma procedimental inerente ao sistema acusatório. O diálogo entre as partes deve ser realizado perante o mesmo juiz no decorrer de todo o processo. Este deve observar todos os argumentos da acusação e da defesa e os meios de prova apresentados. Somente desse modo, o juiz é capaz de decidir quais os argumentos lhe servem melhor na formação de seu livre convencimento.

\footnotetext{
${ }^{32}$ GRINOVER, Ada Pellegrini. As garantias constitucionais do processo. In: Novas tendências do direito processual: de acordo com a constituição de 1988. $2^{\mathrm{a}}$ Ed. Rio de Janeiro: Forense Universitária, 1990. 4-5 p.

${ }^{33}$ NERY JUNIOR, Nelson. Princípios do Processo Civil na Constituição Federal. São Paulo: Revista dos Tribunais, 1995, 138 p. In: ABADE, Denise Neves. Op. cit., 213-214 p.

${ }^{34}$ MENDONÇA JR., Delosmar. Princípios da ampla defesa e da efetividade no processo civil brasileiro. São Paulo: Malheiros, 2001. In: ALMADA, Roberto José Ferreira de. A Garantia processual da publicidade. São Paulo: Editora Revista dos Tribunais, 2006. 124 p.
} 
É, também, através da oralidade que a participação das partes no processo se torna efetiva. A oralidade não é somente questão de forma dos atos, é verdadeira condição de validade dos atos processuais ${ }^{35}$.

A publicidade é garantia de informação às partes do processo e ao público em geral. É garantia que atua com a oralidade, a legalidade e a motivação das sentenças para dar transparência à estrutura processual, possibilitando o controle no âmbito interno e externo das atividades públicas ${ }^{36}$.

A publicidade pode ser dividida em interna e externa. A publicidade interna permite que as partes possam efetivamente participar da relação, visto que o contraditório está condicionado a essa publicidade. É necessário, em primeiro lugar, deter a informação para, depois, reagir. Sem a informação e a clareza de quaisquer atos atinentes ao processo, o direito de defesa fica prejudicado, assim como o próprio contraditório, frustrandose as expectativas da tutela jurisdicional da defesa.

No mais, a extensão da publicidade aos atos preliminares é também direito do indiciado, visto que o seu direito de defesa está condicionado ao exercício do contraditório. Portanto, não se pode negar a publicidade absoluta na investigação sob pena de prejudicar o direito de defesa posteriormente no processo caso seja a ação penal deflagrada ${ }^{37}$.

A publicidade externa tem o objetivo dar legitimidade através da transparência dos atos processuais ou de quaisquer outros atos realizados pelos órgãos estatais. Será o público o maior interessado na fiscalização destes atos e na gestão da coisa pública conforme os princípios da administração pública, já que a coletividade preza pelo espírito democrático e pelo regular exercício dos órgãos públicos ${ }^{38}$.

\footnotetext{
${ }^{35}$ Prado, Geraldo. Op. cit., 153-158 p.

${ }^{36}$ LOPES JUNIOR, Aury. Ob. cit., 191-192 p.

${ }^{37}$ ALMADA, Roberto José Ferreira de. Op. cit., 122-127 p.

${ }^{38}$ Ibid. 134 p.
} 
Ressalvados os atos que necessariamente possam atingir outros direitos fundamentais, como a intimidade e a privacidade, a publicidade é regra como é previsto nos seguintes artigos:

Art. $5^{\circ}$, inciso LX da CR/88:

"a lei só poderá restringir a publicidade dos atos processuais quando a defesa da intimidade ou o interesse social o exigirem".

E o art. 93, IX do mesmo diploma:

"todos os julgamentos dos órgãos do Poder Judiciário serão públicos, e fundamentadas todas as decisões, sob pena de nulidade, podendo a lei limitar a presença, em determinados atos, às próprias partes e a seus advogados, ou somente a estes, em caso nos quais a preservação do direito à intimidade do interessado no sigilo não prejudique o interesse público à informação".

\section{Por fim, segundo EDUARDO COUTURE ${ }^{39}$ :}

"o princípio da publicidade é imprescindível para a fixação do conceito de processo justo e équo, sendo o único meio capaz de garantir a lisura e a transparência dos atos judiciais e permitir o controle e a fiscalização popular".

\subsection{Sistema acusatório na Constituição da República de 1988}

\subsubsection{O sistema eleito pela $\mathrm{CR} / 88$}

O pressuposto do Estado Democrático de Direito é dar relevância necessária à Constituição, lei maior que prevê as normas, princípios e garantias relacionados aos direitos fundamentais, divisão de poderes e democracia. Desse modo, os princípios fundamentais e políticos do processo serão os responsáveis pela forma e pela caracterização dos sistemas de processo, orientando a atividade processual do Estado ${ }^{40}$.

Dessa forma, ensina JOSÉ FREDERICO MARQUES ${ }^{41}$ sobre relevância dos princípios postulados na Constituição na definição e direção do processo:

\footnotetext{
${ }^{39}$ COUTURE, Eduardo. Fundamentos del derecho procesal civil. $4^{\text {a }}$ Ed. Buenos Aires: Júlio César Faira Editor, 2002. In: ALMADA, Roberto José Ferreira de. Op. cit., 129 p.

${ }^{40}$ MARQUES, José Frederico. Elementos de Direito Processual Penal. $2^{\mathrm{a}}$ ed. Rio de Janeiro: Forense, 1965. 59-60 p.

${ }^{41}$ MARQUES, José Frederico. Do Processo Penal Acusatório. In: Estudos de direito processual penal. Rio de Janeiro: Forense. 1960. 25 p.
} 
“(...) patente está que as leis ordinárias do direito judiciário penal, em nosso país, devem consagrar, em face das garantias acima expostas, o sistema acusatório, e repelir, por isso mesmo, o procedimento inquisitivo, tanto mais que, estatuída a separação e independência de poderes (...), o órgão julgador encarna uma função soberana do Estado, distinta da dos demais poderes".

É necessário aliar devidamente os princípios nela postulados com a eficiência do processo penal moderno que se encontra em constante evolução $^{42}$, pois como afirma GONZALES-CUELLAR ${ }^{43}$, é preciso ponderar os princípios constitucionais e os interesses no campo da persecução penal através do princípio da proporcionalidade em busca da Justiça Penal, pois os princípios podem conviver com metas de política criminal.

Portanto, no que tange as garantias processuais, CHIAVARIO ${ }^{44}$ também concorda que o princípio da proporcionalidade é aplicado nessa relação de direitos individuais e interesse persecutório estatal.

\section{Segundo CANDIDO RANGEL DINAMARCO ${ }^{45}$ :}

"o processualista moderno adquiriu a consciência de que, como instrumento a serviço da ordem constitucional, o processo precisa refletir as bases do regime democrático, nela proclamadas; (...)".

ADA PELLEGRINI GRINOVER ${ }^{46}$ afirma que o único sistema processual penal de um Estado Democrático de Direito poderia ser o acusatório, onde a divisão de funções dos sujeitos do processo é nítida e prevaleça a imparcialidade do julgador. E, de forma alguma, existiria um conflito entre o garantismo e a eficiência penal, ao contrário, o processo penal deve estar ajustado à realidade moderna que está direcionada tanto para os fins jurídicos quanto para os fins sociais ${ }^{47}$.

\footnotetext{
${ }^{42}$ ABADE, Denise Neves. Ob. cit., 118 e 125 p.

${ }^{43}$ GONZALES-CUELLAR SERRANO, Nicolas. Proporcionalidad y derechos fundamentales em el proceso penal. Madrid: Ed. Colex, 1990. 21 e 313 p. In: ABADE, Denise. Ob. cit., 120 p.

${ }^{44}$ CHIAVARIO, Mario. Direitos humanos, Processo Penal e criminalidade organizada in Revista Brasileira de Ciências Criminais, v.2, nº 5, jan-mar, 1994, 25-36. In: ABADE, Denise. Ob. cit. 128 p.

45 DINAMARCO, Cândido Rangel. A instrumentalidade do Processo. $3^{\text {a }}$ Ed. São Paulo: Malheiros, 1993. 27 p. In: PRADO, Geraldo. Ob. cit., 28 p.

${ }^{46}$ GRINOVER, Ada Pellegrini. Liberdades Públicas e Processo Penal. 56 p. In: PRADO, Geraldo. Ob. cit., 33 p.

${ }^{47}$ GRINOVER, Ada Pellegrini. O processo em evolução. $2^{\mathrm{a}}$ ed. Rio de Janeiro: Forense Universitária, 1998. 206 p.
} 
Ainda nesse sentido, DENISE ABADE ${ }^{48}$ sustenta que os interesses do indivíduo e da sociedade não são opostos:

"O devido processo penal encontra intima correlação com o sistema acusatório. Isso porque, nos Estados de Direito contemporâneos, a definição de devido processo legal relaciona-se diretamente, dentre outras, às garantias do acesso à Justiça, da imparcialidade do Juízo e do contraditório (...). Estes conceitos perfilam os contornos de garantias que delimitam o sistema acusatório. Por essa razão, uma noção contemporânea de devido processo penal leva necessariamente ao conceito de sistema acusatório".

\section{JOSÉ FREDERICO MARQUES ${ }^{49}$ também declara que pela} previsão constitucional da ampla defesa e da instrução contraditória ${ }^{50}$, somente o sistema acusatório pode ter acolhida. $\mathrm{O}$ direito brasileiro não deixa de consagrar a igualdade das $\operatorname{partes}^{51}$ (art. $5^{\circ}$, caput, da CR/88), a imparcialidade do juiz ${ }^{52}$ (art. 5 , LIII e XXXVII) e a titularidade da pretensão punitiva concedida ao Ministério Público ${ }^{53}$, não havendo espaço para a figura do juiz inquisitivo.

A supremacia do princípio democrático e as escolhas principiológicas dos direitos fundamentais previstos na Carta Constitucional permitem concluir que a $\mathrm{CR} / 88$ elegeu o sistema acusatório como a base de todo o sistema legislativo, mas, infelizmente, essa escolha feita pela Constituição é meramente formal ${ }^{54}$ e produz eficácia simbólica ${ }^{55}$. Os princípios se encontram em contradição com as normas da legislação ordinária que reclamam, urgentemente, por reformas integrais.

\footnotetext{
${ }^{48}$ ABADE, Denise. Ob. cit., 126-127 p.

49 MARQUES, José Frederico. Elementos de Direito Processual Penal. $2^{\mathrm{a}}$ ed. Rio de Janeiro: Forense, 1965. 63-64 p.

${ }^{50}$ Art. $5^{\circ}, \mathrm{LV}$, da CR/88: aos litigantes, em processo judicial ou administrativo, e aos acusados em geral são assegurados o contraditório e ampla defesa, com os meios e recursos a ela inerentes.

${ }^{51}$ Art. $5^{\circ}$, caput, da CR/88: Todos são iguais perante a lei, sem distinção de qualquer natureza, garantindo-se aos brasileiros e aos estrangeiros residentes no País a inviolabilidade do direito à vida, à liberdade, à igualdade, à segurança e à propriedade, nos termos seguintes.

52 Art. 5 $5^{\circ}$ XXVII, da CR/88: não haverá juízo ou tribunal de exceção; e LIII: ninguém será processado nem sentenciado senão pela autoridade competente

53 Art. 129, I, da CR/88: São funções institucionais do Ministério Público: I - promover, privativamente, a ação penal pública, na forma da lei.

54 MALAN, Diogo Rugde. Palestra "Inovações nas Provas (Lei 11.690). In: Seminário “A Reforma do Código de Processo Penal".

${ }^{55}$ PRADO, Geraldo. Ob. cit., 242 p.
} 


\subsubsection{Controvérsias ao sistema eleito}

Discorda destes autores, JACINTO NELSON DE MIRANDA COUTINHO $^{56}$, ao afirmar que o modelo sistemático brasileiro é essencialmente inquisitorial com características acusatórias de segundo plano e misto formalmente.

Considera como fundamental na indicativa classificação do sistema vigente a gestão da prova confiada ao juiz ${ }^{57}$, como ocorre, por exemplo, na possibilidade de instauração de ofício de inquérito pelo magistrado (art. $5^{\circ}$, II, CPP/41) e na determinação de produção de provas e diligências (art.156, $\mathrm{CPP} / 41)$.

Nesse sentido, o autor critica a estrutura processual penal e suplica pela devida superação deste sistema ao afirmar que é necessária uma reforma integral em busca de um principio unificador e a exclusão do inquérito policial. Concordamos quando fala da preocupação do Estado Democrático de Direito com a igualdade ${ }^{58}$ e o novo papel do juiz na tutela jurisdicional, quando passa de mero aplicador da norma a sujeito atuante na busca pela igualdade material das partes no processo de estrutura dialética.

AURY LOPES JR. ${ }^{59}$ não aceita a tese de sistema misto e concorda com JACINTO COUTINHO quando este fala que o princípio informador do sistema processual penal é o inquisitório.

Discorda de grande parte da doutrina quando afirma que a simples divisão das atividades de julgar e acusar não é suficiente para determinar qual o sistema processual vigente, sendo a gestão de provas na forma pela

\footnotetext{
${ }^{56}$ COUTINHO, Jacinto Nelson de Miranda. O papel do novo juiz no processo penal. In: Crítica à teoria geral do direito processual penal. Rio de Janeiro: Renovar, 2001. 3-56 p.

${ }^{57} \mathrm{O}$ autor diz que o princípio da inércia da jurisdição é inerente ao sistema acusatório e significa dizer que a jurisdição não pode ser desempenhada de ofício pelo juiz para que assim não prejudique a sua imparcialidade. COUTINHO, Jacinto Nelson de Miranda. Introdução aos princípios gerais do direito processual penal brasileiro. In: Revista de Estudos Criminais. Porto Alegre, n.1, 26-51 p. 2001. 37-38 p.

${ }^{58}$ Art. $5^{\circ}$, caput, da CR/88: "Todos são iguais perante a lei, sem distinção de qualquer natureza, garantindo-se aos brasileiros e aos estrangeiros residentes no País a inviolabilidade do direito à vida, à liberdade, à igualdade, à segurança e à propriedade, nos termos seguintes".

${ }^{59}$ LOPES JUNIOR, Aury. Op. cit., $174-176$ p.
} 
qual é realizada, o que identifica o princípio unificador do sistema processual.

Em sentido contrário, destaca ADA PELLEGRINI GRINOVER que "o conceito de processo acusatório e de processo de partes (...) nada tem a ver com a iniciativa instrutória do juiz no processo penal".

\subsubsection{Sistema acusatório e poderes instrutórios do juiz}

ADA PELLEGRINI GRINOVER ${ }^{60}$ sustenta que o direito processual tem autonomia e seus fins se misturam com os próprios fins do Estado Democrático de Direito. O processo adquire uma função social que necessita ser efetiva e, por isso, não há como conceber a idéia de juiz neutro, inerte:

"não pode ele ser visto como mero espectador de um duelo judicial de interesse exclusivo dos contendores. Se o objetivo da atividade jurisdicional é a manutenção da integridade do ordenamento jurídico, para o atingimento da paz social, o juiz deve desenvolver todos os esforços para alcançá-lo".

O juiz tem um papel ativo, devendo incentivar o contraditório e a produção de provas na tentativa de equilibrar o processo de partes que estão constantemente em desequilíbrio, seja pela falta de capacidade econômica, seja pela capacidade técnica das partes. Por isso, não deve se contentar com as provas dispostas pelas partes, pois ninguém melhor que o juiz para avaliar se aquelas provas serão suficientes para a formação de seu livre convencimento.

"Isso não significa que a busca da verdade seja o fim do processo e que o juiz só deva decidir quando a tiver encontrado. Verdade e certeza são conceitos absolutos, dificilmente atingíveis, no processo ou fora dele. Mas é imprescindível que o juiz diligencie a fim de alcançar o maior grau de probabilidade possível”.

Por essa razão, a autora considera que a possibilidade de o juiz determinar certas diligências é compatível com o Estado Democrático de Direito, pois o processo é um instrumento de justiça e o juiz deve, por meio

${ }^{60}$ GRINOVER, Ada Pellegrini. A iniciativa instrutória do juiz no processo acusatório. In: A marcha do processo. Rio de Janeiro: Forense Universitária, 2000. 77-86 p. 
dele, prestar a melhor tutela jurisdicional. Não haveria violação à imparcialidade do julgador, ao contrário, ela estaria mais reforçada por conta do equilíbrio das partes do processo.

O juiz, ao determinar diligências não se torna parcial, pois não tem como prever o resultado daquela produção de prova a ser realizada. Além do mais, existem limites inerentes a essas atividades instrutórias, como a previsão do "contraditório, a obrigatoriedade de motivação, os limites impostos pela licitude (material) e legitimidade (processual) das provas".

Todos os limites inerentes a essa atividade estarão a postos para permitir uma efetiva participação das partes processuais, pois como diz a autora o processo tem uma "estrutura cooperatória, em que a garantia de imparcialidade da jurisdição brota da colaboração entre partes e juiz". ${ }^{61}$

Certo é lembrar que ADA PELLEGRINI sustenta estas atribuições à atividade do juiz realizada no decorrer do processo e não à fase de investigação preliminar, ressalvada a situação em que tem a função (função de garantidor dos direitos fundamentais) de determinar as medidas cautelares, em que é necessária a requisição pelo Ministério Público e/ou pela Polícia Judiciária. "Por isso, é oportuno que o juiz da investigação prévia (...) seja diverso do juiz do processo".

FREDERICO MARQUES ${ }^{62}$ também concorda com a posição de ADA PELLEGRINI e afirma que a concessão de poderes instrutórios ao juiz é inerente ao Estado Democrático de Direito, desde que respeitados os limites necessários à atividade jurisdicional:

"Certos poderes conferidos pelo código ao juiz, como os de requisitar inquéritos (art. 5, n. ${ }^{\circ}$ II) remeter papéis ao Ministério Público para oferecimento da denúncia (art. 40), não constituem derrogação das normas acusatórias do processo, porquanto o magistrado que assim procede não se sobrepõe aos órgãos da acusação, mas apenas dá a noticia criminis a quem de direito. Tanto isto é verdade, que o Ministério Público pode pedir o arquivamento de inquérito cuja abertura foi requisitada pelo juiz, e também das peças que este lhe enviar para oferecimento da denúncia”.

\footnotetext{
${ }^{61}$ GRINOVER, Ada Pellegrini. As garantias constitucionais do processo. In: Novas tendências do direito processual: de acordo com a constituição de 1988. $2^{\mathrm{a}}$ Ed. Rio de Janeiro: Forense Universitária, 1990. 2-3 p.

${ }^{62}$ MARQUES, José Frederico. Do Processo Penal Acusatório. In: Estudos de direito processual penal. Rio de Janeiro: Forense. 1960. 27-28 p.
} 


\subsection{O sistema acusatório da CR/88 e o CPP/41}

O que se verifica no Código de Processo Penal de 1941 é um conjunto de resquícios de inquisitorialismo presente nas normas as quais não foram recepcionadas pela Constituição Federal de 1988. A CR/88 é clara quando faz referência aos princípios do contraditório, da igualdade, do Juiz Natural e da presunção de inocência ${ }^{63}$.

A incompatibilidade de normas e princípios reclama por uma reforma no Código de Processo Penal que, flagrantemente, reúne normas inconstitucionais e contrárias à própria idéia de democracia e devido processo penal.

\subsubsection{O juiz e a instauração do inquérito policial ex officio}

A imparcialidade do juiz no processo penal é revestida pelo princípio do Juiz Natural previsto no art. $5^{\circ}$, inciso XXXVII da CR/88: "Não haverá juízo ou tribunal de exceção" e no inciso LIII: "ninguém será processado nem sentenciado senão pela autoridade competente", além de ser garantia almejada por diversos diplomas internacionais vigentes no Brasil ${ }^{64}$.

É, portanto, o princípio do Juiz Natural ${ }^{65}$ garantia constitucional da isonomia das partes, da própria jurisdição e pressuposto da imparcialidade do juiz que, assim como para qualquer exercício de outro órgão do Estado, está restrito ao princípio da impessoalidade ${ }^{66}$.

\footnotetext{
${ }^{63}$ ABADE, Denise. Ob. cit. 143-144 p.

${ }^{64}$ Denise Abade cita os diplomas internacionais que prestigiam a garantia à imparcialidade do juízo: art. X da Declaração Universal dos Direitos do Homem e do Cidadão, de 1948 ("tribunal independente e imparcial"); o n. 1 do art. 14 do Pacto Internacional sobre Direitos Civis e Políticos, promulgado pelo Decreto 592, de 6.7.92 ("tribunal competente, independente e imparcial"); e art. $8^{\circ}$ da Convenção Americana de Direitos Humanos (Pacto de São José da Costa Rica que diz que "toda pessoa tem direito a ser ouvida com as devidas garantias e dentro de um prazo razoável, por um juiz ou tribunal competente, independente e imparcial”). ABADE, Denise. Ob. cit., $141 \mathrm{p}$.

${ }^{65}$ COUTINHO, Jacinto Nelson de Miranda. Introdução aos princípios gerais do direito processual penal brasileiro. In: Revista de Estudos Criminais. Porto Alegre, n.1, 2001. 34 p.
}

${ }^{66}$ PRADO, Geraldo. Ob. cit., 109-110 p. 
O Código de Processo Penal prevê no art. $5^{\circ}$, inciso II $^{67}$, a possibilidade de o juiz requisitar a instauração do inquérito policial em ação penal pública. Essa previsão legal, segundo GERALDO PRADO ${ }^{68}$, é algo que compromete o direito do acusado à imparcialidade do juiz, pois pela existência do crime o magistrado poderia emitir um juízo de valor a priori quanto ao fato delituoso.

É o que afirma, também, DENISE ABADE ${ }^{69}$ ao dizer que o legislador violou o sistema acusatório na redação do art. 5, II do Código de Processo Penal e, por isso, este artigo não teria sido recepcionado pela $\mathrm{CR} / 88$. Porém, o legislador continuou a prever a figura do juiz inquisitor nas leis posteriores à Constituição Federal de 1988, como é no caso das Leis 9.094/95, 9.296/96 e 9.613/98.

\subsection{2. $O$ juiz e a gestão de provas}

Ainda assim, o autor sustenta a inconstitucionalidade do artigo 156 do Código de Processo Penal ${ }^{70}$, pois permite que o juiz ordene de ofício a produção de provas, antes e depois de instaurada a ação penal, o que nada mais é do que atuar como juiz-investigador, mesmo que a atuação esteja dirigida a dirimir dúvida sobre ponto relevante.

GERALDO PRADO diz que a gestão das provas é situação que apenas compete às partes do processo, principalmente no caso da Acusação que deve desconstruir a situação de inocência do réu. Portanto, deveria o magistrado manter sua postura eqüidistante da produção de provas para

\footnotetext{
${ }^{67}$ Art. 5', II, do CPP: "Nos crimes de ação penal pública o inquérito policial será iniciado mediante requisição da autoridade judiciária ou do Ministério Público, ou a requerimento do ofendido ou de quem tiver qualidade para representá-lo".

${ }^{68}$ PRADO, Geraldo. Op. cit., 173-183 p.

69 "Tais leis contemplam uma larga margem de interferência do juiz na fase de investigação e, mesmo severamente criticadas pela doutrina, ainda não tiveram sua constitucionalidade negada". Segundo a autora, $\mathrm{o}$ art. $3^{\circ}$ da Lei n. 9.034/95 prevê o juiz como sujeito ativo na colheita de provas e a perda da imparcialidade do juiz com a quebra da paridade das armas. Ainda nesse sentido, a Lei n.9.296/96 permitiu tornou possível que a interceptação telefônica fosse determinada por iniciativa judicial ainda na fase de investigação. E, por fim, a Lei n.9.613/98 que também permite que o juiz assuma uma posição ativa na colheita de provas, conforme se verifica no art. $4^{\circ}$ da lei.

${ }^{70}$ Art. 156 do CPP/1941: "A prova da alegação incumbirá a quem a fizer; mas o juiz poderá, no curso da instrução ou antes de proferir sentença, determinar, de ofício, diligências para dirimir dúvida sobre ponto relevante".
} 
evitar qualquer tipo de envolvimento, mesmo inconsciente, com as provas ainda não inseridas no processo.

DENISE ABADE ${ }^{71}$ partilha deste mesmo entendimento, ou seja, a competência para iniciar a produção de provas é das partes processuais (cf. $1^{a}$ parte do art. 156 do $\left.\mathrm{CPP} / 41\right)$, mas faz ressalva quanto à interpretação restrita que deve ser dada à segunda parte deste artigo. Considera que a iniciativa probatória do juiz deve ser encarada como "suplementar" a iniciativa da defesa e, por isso, com o objetivo de equilibrar o processo das partes na busca da melhor prestação da tutela jurisdicional.

JOSÉ FREDERICO MARQUES ${ }^{72}$ também rechaça a previsão no Código de Processo Penal de 1941 de juiz gestor de provas. Ele diz que além do poder de julgar há funções que são inerentes a sua atividade:

"atribuições persecutórias, ele as tem muito restritivas, e assim mesmo confinadas ao campo da notitia crimini. No que tange com a ação penal e à função de acusar, sua atividade é praticamente nula (...). Certo é que a lei processual autoriza o juiz a, ex officio investigar a verdade. Fá-lo, porém, subsidiariamente como de maneira clara se vê do art. 156 do Cód. de Proc. Penal (...)".

\subsubsection{A imparcialidade e o controle dos elementos de informação}

A situação de imparcialidade antes e depois do processo requer do magistrado seu afastamento da atividade preparatória, mas não é o que ocorre no caso da fiscalização e do controle dos elementos de informação constantes no inquérito policial e do pedido de arquivamento do Ministério Público condicionado à autorização judicial. Segundo GERALDO PRADO $^{73}$ :

"a intervenção judicial, voltada ao controle da realização das investigações básicas para a deflagração da ação penal, é algo completamente anômalo, a ser expurgado do ordenamento jurídico, sob pena de violação das regras básicas pertinentes à distribuição de funções, com a garantia para o acusado da imparcialidade do seu julgador".

Portanto, a reserva jurisdicional nesta etapa somente permite que o juiz atue mediante requerimento da Polícia e do Ministério Público de

\footnotetext{
${ }^{71}$ ABADE, Denise Neves. Op. cit., 156-157 p.

${ }^{72}$ MARQUES, José Frederico. Op. cit., 64-65 p.

${ }^{73}$ PRADO, Geraldo. Ob. cit., 179 p.
} 
providências cautelares a fim de proteger os direitos fundamentais, conforme prevê o art. $5^{\circ}$, inciso XXXV, da $\mathrm{CR} / 88$ : "a lei não excluirá da apreciação do Poder Judiciário lesão ou ameaça de direito ${ }^{74, "}$

AURY LOPES JR. $^{75}$ também censura essa manipulação dos elementos de informação do inquérito policial pelo juiz no caso do art. 157 do Código de Processo Penal de 1941. Nesta situação, ao juiz é permitido fazer a livre apreciação da prova, mas nada é falado sobre a restrição dos elementos de informação colhidos no inquérito.

$\mathrm{O}$ inquérito policial é anexado os autos da ação penal e, por isso, o magistrado acaba por ter contato com provas que não foram submetidas ao contraditório. Sendo assim, mesmo que inconsciente, a prova colhida neste momento acaba sendo utilizada pelo juiz para corroborar a sua decisão.

\subsubsection{O Ministério Público e sua independência}

O Ministério Público é o órgão responsável pela Acusação e somente cabe a ele, promover a ação penal pública conforme previsão no art. 129, I, da $\mathrm{CR} / 88^{76}$ e compor o conflito, apresentando as provas contra a defesa.

O Ministério Público é órgão independente com função de defesa impessoal da ordem jurídica, do regime democrático e dos interesses sociais e individuais indisponíveis. É órgão distinto do juiz, procurando atender a regras estritas de legalidade, não estando sujeito a qualquer outro órgão do Estado. $^{77}$

\footnotetext{
74 "Portanto, é estranho ao sistema acusatório (...) o poder do juiz, por exemplo, de ofício decretar a prisão preventiva do indiciado (art. 311 do Código de Processo Penal: "Em qualquer fase do inquérito policial ou da instrução criminal, caberá a prisão preventiva decretada pelo juiz, de ofício, a requerimento do Ministério Público, ou do querelante, ou mediante representação da autoridade policial)". PRADO, Geraldo. Ob. cit., 182 p.

${ }^{75}$ LOPES JUNIOR, Aury. Op. cit., 175-177 p.

76 Art. 129, I da CR/88: "São funções institucionais do Ministério Público: promover, privativamente, a ação penal pública, na forma da lei".

${ }_{77}$ MORAES, Alexandre de. Direito Constitucional. 17 $7^{a}$ Ed. São Paulo: Editora Atlas, 2005. 536$538 \mathrm{p}$.
} 
Portanto, contrária está a regra prevista no art. 385 do Código de Processo Penal ${ }^{78}$ que permite o juiz proferir sentença quando o Ministério Público pedir a absolvição do réu, ainda assim viola a imparcialidade do magistrado e o princípio do contraditório, como afirma GUSTAVO HENRIQUE BADARÓ ${ }^{79}$ quando fala que "a regra da correlação entre acusação e sentença é uma decorrência do principio do contraditório".

\subsection{5. $O$ direito de defesa}

Ao acusado é garantido o direito de defesa através da sua possibilidade efetiva de participação no processo. Conforme previsto no art. $5^{\circ}$, inciso LV da CR/88: "aos litigantes, em processo judicial ou administrativo, e aos acusados em geral são assegurados o contraditório e ampla defesa, com os meios e recursos a ela inerentes".

Mesmo que sua situação de acusado ainda não tenha sido formalizada, observa-se que a publicidade interna, no caso àquela pertinente somente às partes, permite ao indiciado e a seu defensor ter o direito de acesso a quaisquer informações que constem em inquérito policial, pois é esse direito à informação que torna possível às partes exercerem o contraditório e preparar eficazmente o direito de defesa.

O Código de Processo Penal de 1941 no seu artigo 20 faz referência à limitação da publicidade interna ao permitir que a autoridade policial assegure o sigilo necessário ao inquérito policial ${ }^{80}$ para fins de persecução penal e o bom andar da investigação. Tal norma é incompatível com o sistema acusatório eleito pela CR/88. Segundo GERALDO PRADO ${ }^{81}$ :

"há atos que precisam permanecer sob sigilo, durante algum tempo, sob pena de fracassarem os fins da própria investigação (...). De todo modo, quando as condições de participação da Defesa são canceladas, os atos eventualmente

\footnotetext{
78 Art. 385 do CPP: "Nos crimes de ação pública, o juiz poderá proferir sentença condenatória, ainda que o Ministério Público tenha opinado pela absolvição, bem como reconhecer agravantes, embora nenhuma tenha sido alegada".

${ }^{79}$ BADARÓ, Gustavo Henrique R. Ivahy. Correlação entre acusação e sentença. São Paulo: RT, 2000. 27 p. In: PRADO, Geraldo. Ob. cit., 117 p.

${ }^{80}$ Art. 20, caput, do CPP: “A autoridade policial assegurará no inquérito o sigilo necessário à elucidação do fato ou exigido pelo interesse da sociedade".

${ }^{81}$ PRADO, Geraldo. Ob. cit., 122-123 p.
} 
realizados podem estar entre dois extremos: são simplesmente informativos, e o juiz não poderá considerá-los no processo. Quando muito os levará em conta para ajuizar a presença de justa causa para a ação penal; ou não valerão de modo algum".

A questão é bastante controvertida e o STJ já manifestou entendimento contrário ao acesso do advogado, mesmo com procuração, aos autos de inquérito policial, a não ser que houvesse cerceamento de liberdade do indiciado ${ }^{82}$.

Em posição contrária, entende o STF que a restrição da defesa ao inquérito policial poderá reproduzir-se em prejuízo de defesa no processo e, embora ao inquérito não seja permitida a aplicação do contraditório nem da ampla defesa, a existência de direitos fundamentais do indiciado autoriza o advogado a ter o devido acesso aos autos do procedimento administrativo em questão, conforme art. $7^{\circ}, \mathrm{XIV}$, da Lei n. $8.906 / 94^{83}$. Segundo o acórdão da Suprema Corte ${ }^{84}$ :

"a oponibilidade ao defensor constituído esvaziaria uma garantia constitucional do indiciado (CF, art. $5^{\circ}$, LXIII), que lhe assegura, quando preso, e pelo menos lhe faculta, quando solto, a assistência técnica do advogado, que este não lhe poderá prestar se lhe é sonegado o acesso aos autos do inquérito sobre o objeto do qual haja o investigado de prestar declarações"

A solução é trazida pela mesma corte e no mesmo acórdão quando sustenta que:

"dispõe, em conseqüência a autoridade policial de meios legítimos para obviar inconvenientes que o conhecimento pelo indiciado e seu defensor dos autos do inquérito policial possa acarretar à eficácia do procedimento investigatório".

A questão se encontra pacificada conforme súmula vinculante $\mathrm{n}^{\circ} 14$ do Supremo Tribunal Federal de 9 de fevereiro de 2009:

"É direito do defensor, no interesse do representado, ter acesso amplo aos elementos de prova que, já documentados em procedimento investigatório realizado por órgão com competência de polícia judiciária, digam respeito ao exercício do direito de defesa".

De todo modo, a Suprema Corte parece acompanhar a tese dos direitos fundamentais do acusado, assim como entende CANDIDO

\footnotetext{
${ }^{82}$ STF, RMS n. 12.754-PR, Rel. Ministro Franciulli Netto, Brasília, 11 de março de 2003.

${ }^{83}$ Art. $7^{\circ}$, XIV do Estatuto da OAB: "São direitos do advogado: examinar qualquer repartição policial, mesmo sem procuração, autos de flagrante e de inquérito, findos ou em andamento, ainda que conclusos à autoridade, podendo copiar peças e tomar apontamentos".

${ }^{84}$ STF, HC n. 82.35-PR, Rel. Ministro Sepúlveda Pertence, Brasília, DJ de 24.09.2004
} 
RANGEL DINAMARCO ${ }^{85}$ ao dizer que às partes e a seu defensor não pode ser suprimida a garantia da publicidade, pois o contraditório está efetivamente condicionado a publicidades das informações.

${ }^{85}$ DINAMARCO, Cândido Rangel. Instituições de direito processual civil. V. 1 a 3, $2^{\text {a }}$ Ed. São Paulo: Malheiros Editores, 2002. In: ALMADA, Roberto José Ferreira de. Op. cit., 129-130 p. 


\section{Capitulo 2- Contraditório e Prova Penal}

\subsection{Garantias da Investigação Criminal}

À primeira vista nos parece que a fase de investigação não está voltada aos direitos fundamentais do investigado, mas não é correto pensar dessa forma em virtude dos valores democráticos adotados. A repressão estatal na liberdade do indivíduo é suficiente para ensejar a adoção de direitos e garantias constitucionais já na fase pré-processual.

É necessário adequar os valores democráticos da CR/88 à atuação repressiva do Estado no que for possível e adequado à natureza do inquérito policial, embora o Código de Processo Penal de 1941 tenha postulado de forma diferente em nome de uma política de repressão à criminalidade.

De todo modo, a matriz acusatória da Constituição estabelece a dignidade da pessoa humana ${ }^{86}$ como fundamento do Estado Democrático de Direito e, como fundamento, é exigido do Estado que este se submeta a uma nova postura ética e democrática em relação ao indivíduo, independentemente de sua localização dentro do processo ${ }^{87}$.

\subsubsection{Inquérito Policial}

$\mathrm{O}$ inquérito policial ${ }^{88}$ é procedimento administrativo de persecução criminal, de instrução provisória ${ }^{89}$, escrito ${ }^{90}$, sigiloso $^{91}$ e de competência da

\footnotetext{
${ }^{86}$ Art. $1^{\circ}$, III da CR/88: "A República Federativa do Brasil, formada pela união indissolúvel dos Estados e Municípios e do Distrito Federal, constitui-se em Estado Democrático de Direito e tem como fundamentos: a dignidade da pessoa humana".

${ }^{87}$ CHOUKR, Fauzi Hassan. Garantias constitucionais na investigação criminal. $3^{\mathrm{a}}$ ed. Rio de Janeiro: Lumen Juris, 2006. 3-17 p.

${ }^{88} \mathrm{~N}^{\circ}$ IV da Exposição de Motivos do Código de Processo Penal de 1941: "O inquérito policial, como instrução provisória, antecedendo à propositura da ação penal, constitui uma garantia contra apressados e errôneos juízos, formados quando ainda persiste a trepidação moral causada pelo crime ou antes que seja possível uma exata visão de conjunto de fatos, nas suas circunstâncias objetivas e subjetivas".

${ }^{89}$ MARQUES, José Frederico. Elementos de direito processual penal. V. 1. $2^{\mathrm{a}}$ ed. Rio de Janeiro: Forense, 1965. 151-153 p.
} 
Polícia Judiciária ${ }^{92}$, responsável pela realização dos atos essenciais de investigação. A polícia é órgão da administração do Estado com função de auxiliar o órgão jurisdicional e o Ministério Público nas medidas cautelares e no oferecimento da ação penal, respectivamente.

O inquérito policial, segundo SERGIO PITOMBO ${ }^{93}$, tem um duplo objetivo: o primeiro é proteger o indivíduo de acusações sem fundamento e o segundo é evitar a submissão da Justiça penal a qualquer causa e assim, afogar o Judiciário com outras funções.

Os elementos colhidos na investigação servirão de base para a formação da opinião do titular da ação penal pública, o Ministério Público, sobre o delito, estão dirigidos a justificar o processo (denúncia) ou a não justificá-lo (arquivamento) e a fundamentar pedidos de medidas cautelares.

Embora seja um procedimento administrativo de investigação, inquisitório e destinado a formar um juízo de probabilidade, encontra-se a necessidade de inserir algumas garantias constitucionais, como ensina AURY LOPES JUNIOR ${ }^{94}$ :

"Ao iniciar o estudo do inquérito policial, é importante destacar que estamos analisando um instrumento em crise, que exige uma leitura crítica e sem dúvida constitucional-garantista.(...). É imprescindível uma leitura critica do CPP, para que ele seja adequado à Constituição, e não o contrário. $\mathrm{O}$ sujeito passivo não deve mais ser considerado um mero objeto da investigação, pois, em um Estado de Direito como o nosso, existe toda uma série de garantias e princípios de

\footnotetext{
90 Art. $9^{\circ}$ do Código de Processo Penal: “Todas as peças do inquérito policial serão, num só processado, reduzidas a escrito ou datilografadas e, neste caso, rubricadas pela autoridade".

${ }^{91}$ Art. 20, caput, do Código de Processo Penal: “A autoridade assegurará no inquérito o sigilo necessário à elucidação do fato ou exigido pelo interesse da sociedade". Esse segredo externo é restrito a terceiros em relação ao delito já que é permitido ao defensor o acesso aos autos do inquérito conforme súmula vinculante $\mathrm{n}^{\circ}$ 14, DJ 9.02.2009: "É direito do defensor, no interesse do representado, ter acesso amplo aos elementos de prova que, já documentados em procedimento investigatório realizado por órgão com competência de polícia judiciária, digam respeito ao exercício do direito de defesa".

${ }^{92}$ Art. 144, $\S 1^{\text {o }}$, IV: “A polícia federal, instituída por lei como órgão permanente, organizado e mantido pela União e estruturado em carreira, destina-se a exercer, com exclusividade, as funções de polícia judiciária da União"; $§ 4^{\circ}$, da CR/88: “Às polícias civis, dirigidas por delegados de polícia de carreira, incumbem, ressalvada a competência da União, as funções de polícia judiciária e a apuração de infrações penais, exceto as militares". Art. $4^{\circ}$ do CPP: “A polícia judiciária será exercida pelas autoridades policiais no território de suas respectivas circunscrições e terá por fim a apuração das infrações penais e da sua autoria".

${ }^{93}$ PITOMBO, Sérgio. A evolução do processo penal e o inquérito policial. In: MALAN. Diogo Rudge. Seminário de Processo Penal apresentado na USP.

${ }^{94}$ LOPES JUNIOR, Aury. Sistemas de Investigação Preliminar no Processo Penal. $4^{\mathrm{a}}$ ed. Rio de Janeiro: Lumen Juris, 2006. 145 p.
} 
valorização do individuo que exigem uma leitura constitucional do CPP, no sentido de adaptá-lo à realidade".

\subsubsection{Presunção de Inocência}

A presunção da inocência é princípio fundamental do Estado Democrático de Direito, sendo aplicado ao processo penal e permeável à fase de investigação criminal. Previsto na Declaração dos Direitos do Homem e do Cidadão de $1789^{95}$, foi adotado pela Constituição da República de 1988 no seu artigo 5, inciso LVII, onde diz que "ninguém será considerado culpado até o trânsito em julgado de sentença penal condenatória”.

O princípio da presunção de inocência está garantido por norma nacional constitucional e internacional ratificada pelo Estado Brasileiro, com status constitucional. Além disso, possui uma dupla finalidade, conforme afirma ANTONIO MAGALHÃES GOMES FILHO ${ }^{\mathbf{9 6}}$ :

“(...) é regra processual segundo a qual o acusado não está obrigado a fornecer provas de sua inocência, pois está de antemão presumida; de outro, princípio que impede a adoção de medidas restritiva da liberdade pessoal antes do reconhecimento da culpabilidade, salvo os casos de absoluta necessidade".

A conseqüência desse princípio é atribuir ao órgão de acusação o ônus da prova, ou seja, será o Ministério Público o responsável por desconstruir a presunção do acusado e provar sua culpabilidade com provas submetidas, principalmente, ao contraditório e a outras garantias inerentes ao devido processo legal.

Outra conseqüência da presunção de inocência é o direito que o acusado/investigado tem a não produzir provas contra si mesmo e a

\footnotetext{
${ }^{95}$ Art. 8, 1, primeira parte: "toda pessoa acusada de delito tem direito a que se presuma sua inocência enquanto não se comprove legalmente sua culpa". Tal regra tem valor constitucional conforme art. $5^{\circ}, \S 2^{\circ}$ : "Os direitos e garantias expressos nesta Constituição não excluem outros decorrentes do regime e dos princípios por ela adotados, ou dos tratados internacionais em que a República Federativa do Brasil seja parte".

${ }^{96}$ GOMES FILHO, Antônio Magalhães. O princípio da presunção de inocência na Constituição de 1988 e na Convenção Americana sobre direitos humanos (Pacto de São José da Costa Rica). In: Revista do Advogado no 42. São Paulo: Associação dos Advogados de São Paulo, 1994. 31 p.
} 
cooperar com as atividades investigativas ${ }^{97}$, pois como entende o ANTONIO MAGALHAES GOMES FILHO ${ }^{98}$ :

“(...) admitir-se o contrário equivaleria a transformar o acusado em objeto da investigação, quando sua participação só pode ser entendida na perspectiva da defesa, como sujeito processual. Diante disso, evidente que o seu silêncio jamais pode ser interpretado desfavoravelmente, (...)".

Dessa forma, o princípio da presunção da inocência presume um tratamento digno do investigado que deixa de ser mero objeto de investigação e passa a sujeito de direitos e garantias limitados a essa fase.

\subsubsection{Direito a Não Auto-Incriminação}

$\mathrm{O}$ direito a não produzir provas contra si mesmo vale tanto para o indiciado quanto para a testemunha, pois se manifesta no direito ao silêncio que é garantia constitucional.

Além disso, o Supremo Tribunal Federal, no HC 78.708 Rel. Min. Sepúlveda Pertence, entende que deve a autoridade policial informar ao indiciado sobre esse direito sob pena de ilicitude dos meios de provas e posterior nulidade quanto às informações colhidas.

Segundo o acórdão o direito à informação sobre a escolha de se manter em silêncio tem status constitucional e é instrumento de garantia ao direito de não produzir provas contra si mesmo, conforme art. $5^{\circ}$, inciso LXIII, da CR/88: "o preso será informado de seus direitos, entre os quais o de permanecer calado, sendo-lhe assegurada a assistência da família e de advogado".

\subsubsection{Direito à Informação}

O direito à informação ${ }^{99}$ normalmente deve ser aplicado no momento da prisão em flagrante quando da emissão da chamada nota de culpa. É um

\footnotetext{
${ }^{97}$ Nesse sentido, STF, HC no 83.096-RJ, Rel. Min. Ellen Gracie, Brasília, DJ de 18 de novembro de 2003. "O privilégio contra a auto-incriminação, garantia constitucional, permite ao paciente o exercício do direito de silêncio, não estando, por essa razão, obrigado a fornecer os padrões vocais necessários a subsidiar prova pericial que entende lhe ser desfavorável".

${ }^{98}$ GOMES FILHO, Antônio Magalhães. Op. cit., 32 p.
} 
compromisso ético-democrático com a publicidade dos atos praticados pelos agentes públicos que devem estar adstritos à legalidade.

$\mathrm{O}$ direito à informação exige a identificação da autoridade que efetuou a detenção, a informação quanto aos direitos do preso, entre eles o direito de se manter silente, e a individualização da autoridade policial que lavra o auto de prisão em flagrante. $\mathrm{O}$ art. $5^{\circ}$, inciso LXIV, da CR/88 prevê que "o preso tem direito à identificação dos responsáveis por sua prisão ou por seu interrogatório policial”.

Direito previsto desde a Declaração Universal dos Direitos do Homem de 1948, tem o objetivo de evitar a arbitrariedade proveniente dos atos das autoridades policiais e pressupõe a máxima transparência dos procedimentos realizados em face do indivíduo preso.

A transparência é materializada através da nota de culpa, documento oficial identificador da autoridade competente que realizou a prisão, que indica o local em que o preso se encontra e que tem a função de imediata comunicação à autoridade judiciária e aos familiares ou terceiros indicados sobre a prisão do indivíduo.

A violação dessa garantia constitucional gera a ilegalidade da prisão e o posterior relaxamento da prisão, além de poder ensejar a responsabilidade criminal dos agentes que agiram de forma arbitrária. ${ }^{100}$

\subsubsection{Investigação e Publicidade externa}

A publicidade é princípio constitucional ${ }^{101}$ que enseja transparência dos atos processuais e permite o controle interno e externo de toda a atividade pelo público. A exigência do sigilo na investigação ocorre em situações excepcionais, quanto há eminência de violação à intimidade ou interesse social.

\footnotetext{
${ }^{99}$ É direito constitucional, conforme art. $5^{\circ}$, inciso LXIII, da CR/88: "o preso será informado de seus direitos, entre os quais o de permanecer calado, sendo-lhe assegurada a assistência da família e de advogado".

${ }^{100}$ CHOUKR, Fauzi Hassan. Op. cit., 101-105 p.

${ }^{101}$ Art. $5^{\circ}$, LX, da CF/88: "a lei só poderá restringir a publicidade dos atos processuais quando a defesa da intimidade ou o interesse social o exigirem".
} 
O problema e a grave ameaça a outros direitos do investigado ocorrem quando a mídia excede nas informações e expõe o indiciado e/ou o acusado de forma a lhe antecipar a sua culpa, como declara AURY LOPES JUNIOR $^{102}$ ao afirmar que:

“(...) a publicidade abusiva dos atos de investigação preliminar é, desde o ponto de vista do sujeito passivo, o mais grave prejuízo que pode sofrer o inocente (e assim se presume a todos, até a sentença definitiva), pois coloca-o prematuramente no banco dos acusados. Essa situação leva a que, principalmente nos delitos graves, a imprensa induza a opinião pública a condenar sem prévio juízo. Uma eventual absolvição posterior - ao cabo de alguns anos - não tem o poder de 'restabelecer' na sociedade uma situação que jamais poderia ter sido abandonada: a de inocente".

As legislações constitucionais e infraconstitucionais prevêem mecanismos aptos a garantir a defesa dos direitos individuais do investigado e do acusado e o sigilo externo, respectivamente, nos seus artigos $5^{\circ}, \mathrm{LX}$ da $\mathrm{CR} / 88$ ("a lei só poderá restringir a publicidade dos atos processuais quando a defesa da intimidade ou o interesse público o exigirem") e 20, caput, do Código de Processo Penal ("A autoridade assegurará no inquérito o sigilo necessário à elucidação do fato ou exigido pelo interesse da sociedade").

\subsubsection{Direito à Defesa Técnica}

É permitida ao advogado do indiciado a consulta dos autos da investigação ${ }^{103}$ e o contato direto com seu cliente como expressão da garantia constitucional à defesa técnica ${ }^{104}$.

\footnotetext{
${ }^{102}$ LOPES JUNIOR, Aury. Op. cit., 126 p.

${ }^{103}$ STF, HC nº 88.190-RJ, Rel. Min. Cezar Peluso, de 06.10.2006: há o entendimento de que “A persecução penal, nessa primeira fase, compõe-se de atos de investigação e de atos de instrução. Quem investiga "só rastreia”, pesquisa, indaga, segue vestígios e sinais, busca informações para elucidação de um fato. Uma vez documentada a diligência, passa-se da investigação à instrução que pode dar-se mediante atos transitórios - suscetíveis de serem renovados - ou definitivos, como é o caso da juntada de documentos, os quais se incorporam ao bojo de eventual ação penal, e, salvo falsidade, escusam repetição. É este cunho de definitividade inerente a certos atos que exige garantia ao exercício do direito de defesa já na fase preliminar da persecução penal. Há, é verdade, diligências que devem ser sigilosas, sob o risco de comprometimento do seu bom sucesso. Mas, se o sigilo é aí necessário à apuração e à atividade instrutória, a formalização documental de seu resultado já não pode ser subtraída ao indiciado nem ao defensor, porque, é óbvio, cessou a causa mesma do sigilo (...). A autoridade que conduz o procedimento investigatório pode, assim, impor sigilo ao inquérito policial, quando necessário à elucidação do fato ou exigido pelo interesse da
} 
$\mathrm{O}$ art. 7, inciso XIV, da lei $\mathrm{n}^{\mathrm{o}}$ 8.906/94 diz que são direitos dos advogados:

"examinar em qualquer repartição policial, mesmo sem procuração, autos de flagrante e de inquérito, findos ou em andamento, ainda que conclusos à autoridade, podendo copiar peças e tomar apontamentos".

Apesar dos casos excepcionais de sigilo, basta que exista a procuração assinada para que o advogado tenha acesso aos autos de investigação. É direito do indiciado e/ou acusado ter a plena assistência, embora o contraditório não se verifique na fase pré-processual. Porém, essa assistência somente poderá ser efetiva caso o defensor tenha livre acesso aos autos.

A questão foi amplamente discutida e, hoje, se encontra pacificada conforme súmula vinculante $\mathrm{n}^{\circ} 14$ do Supremo Tribunal Federal de 9 de fevereiro de 2009:

"É direito do defensor, no interesse do representado, ter acesso amplo aos elementos de prova que, já documentados em procedimento investigatório realizado por órgão com competência de polícia judiciária, digam respeito ao exercício do direito de defesa".

\subsection{O Princípio do Contraditório}

\subsubsection{Conceito de Contraditório}

É garantia constitucional ${ }^{105}$ que tem como fundamento político a tese de LUHMANN ${ }^{\mathbf{1 0 6}}$ sobre legitimação pelo procedimento. Essa tese diz que o exercício do poder do Estado direcionado aos seus destinatários só tem

\footnotetext{
sociedade. Mas tal sigilo não pode alcançar o acusado nem seu defensor, no que toca os atos de instrução já realizados e documentados".

104 “(...) é, sem dúvida, indisponível, na medida em que, mais do que garantia do acusado, é garantia da paridade de armas indispensável à concreta atuação do contraditório e, consequentemente, à própria imparcialidade do juiz". GRINOVER, Ada Pellegrini. Defesa, contraditório, igualdade e par condicio na ótica do processo de estrutura cooperatória, In: Novas tendências do direito processual: de acordo com a Constituição de 1988. $2^{\mathrm{a}}$ ed. Rio de Janeiro: Forense Universitária, 1990. 9p.

${ }^{105}$ Art. $5^{\circ}$, inciso LV da CR/88: "aos litigantes, em processo judicial ou administrativo, e aos acusados em geral são assegurados o contraditório e ampla defesa, com os meios e recursos a ela inerentes".

${ }^{106}$ DINAMARCO, Cândido Rangel. O princípio do contraditório e sua dupla destinação. In: Fundamentos do Processo Civil Moderno. $4^{\mathrm{a}}$ ed. São Paulo: Malheiros, 2001. 124-125 p.
} 
legitimidade quando, no decorrer da construção destes atos, há participação desses mesmos destinatários.

Segundo CANDIDO RANGEL DINAMARCO ${ }^{107}$, o princípio do contraditório tem uma dupla destinação:

“(...) significa em primeiro lugar que a lei deve instituir meios para a participação dos litigantes no processo e o juiz deve franquear-lhes esses meios. Mas significa também que o próprio juiz deve participar da preparação do julgamento a ser feito, exercendo ele próprio o contraditório. A garantia deste resolve-se, portanto, num direito das partes e deveres do juiz".

A efetiva participação das partes depende da informação que lhe é dada do ato a ser realizado. A ciência é fornecida através de atos processuais como, por exemplo, a citação, a intimação e a notificação, que estimulando a contrariedade das partes, lhe darão condições de participação no processo $^{108}$.

O contraditório é entendido pelas palavras de JOAQUIM CANUTO MENDES DE ALMEIDA ${ }^{109}$ como a "ciência bilateral dos atos e termos processuais e possibilidade de contrariá-los". É a necessidade de informação e a oportunidade de reação para um contraditório pleno e efetivo.

\section{Segundo ANTÔNIO SCARANCE FERNANDES ${ }^{110}$ :}

“(...) pleno porque se exige a observância do contraditório durante todo o desenrolar da causa, até seu encerramento. Efetivo porque não é suficiente que se dê às partes a possibilidade formal de se pronunciar sobre os atos da parte contrária, sendo imprescindível que lhe sejam proporcionados os meios para que tenha condições reais de contrariá-los. Liga-se, aqui, o contraditório ao princípio da paridade das armas, sendo mister, para um contraditório efetivo, que as duas partes estejam munidas de forças similares".

O contraditório, portanto, no processo penal, deve ser estendido a todas as partes, acusado e seu defensor, inclusive o órgão acusador. Não é

\footnotetext{
${ }^{107}$ Ibid. 124 p.

108 ALMEIDA, Joaquim Canuto Mendes de. Princípio do Contraditório. In: Princípios Fundamentais do Processo Penal. São Paulo: Revista dos Tribunais, 1973.80 p.

${ }^{109}$ Ibid. 82 p.

${ }^{110}$ FERNANDES, Antônio Scarance. Processo Penal Constitucional. $2^{\mathrm{a}}$ ed. São Paulo. Revista dos Tribunais, 2000. 52-53 p.
} 
apenas uma garantia fundamental do acusado, mas, sobretudo, uma garantia de um processo $^{111}$ justo.

\subsubsection{Contraditório e Investigação Preliminar}

Há na doutrina quem fale sobre a aplicação do princípio do contraditório já na fase de investigação preliminar, enfatizando a efetiva participação do investigado/indiciado neste momento.

\section{ROGÉRIO LAURIA TUCCI e JOSÉ ROGÉRIO CRUZ E} TUCCI $^{112}$ afirmam que o princípio do contraditório é absolutamente viável na fase pré-processual, conforme uma leitura extensiva do artigo $5^{\circ}$, inciso $\mathrm{LV}$, da CR/88 que prevê o contraditório aos acusados em geral no âmbito do processo judicial ou administrativo.

A existência do contraditório justifica-se, segundo os autores, porque a fase investigativa é formalmente considerada processo administrativo, embora o legislador tenha utilizado a expressão procedimento. Este processo será base preparatória que dará início à ação penal e, além disso, existiria desde já, um conflito de interesses, uma lide e partes, onde o princípio do contraditório se tornaria indispensável.

Diferentemente deste entendimento, diante da natureza e da finalidade do inquérito policial que não confere condição ainda de acusado ao indivíduo investigado, o contraditório não estaria previsto nesta primeira fase, o que não pode ser confundido com o direito ao acesso do advogado aos autos de investigação ${ }^{113}$.

O Supremo Tribunal Federal ${ }^{114}$ entende que o investigado é sujeito de direitos e garantias constitucionais, porém existe certa limitação quanto ao contraditório e à ampla defesa já que o inquérito policial não é processo:

\footnotetext{
${ }^{111}$ GOMES FILHO, Antônio Magalhães. Direito à prova no processo penal. São Paulo: Revista dos Tribunais, 1997. $138 \mathrm{p}$.

112 TUCCI, Rogério Lauria; TUCCI, José Rogério Cruz e. Devido Processo legal e tutela jurisdicional. São Paulo: Revista dos Tribunais, 1993. 27 p.

${ }_{113}$ CHOUKR, Fauzi Hassan. Op. cit., 123-128 p.

${ }^{114}$ STF, HC n. 82.354-PR, Rel. Min. Sepúlveda Pertence, DJ de 24.09.2004.
} 
"Inaplicabilidade da garantia constitucional do contraditório e da ampla defesa ao inquérito policial, que não é processo, porque não destinado a decidir litígio algum, ainda que na esfera administrativa; existência, não obstante, de direitos fundamentais do indiciado no curso do inquérito, entre os quais o de fazer-se assistir por advogado, o de não se incriminar e o de manter-se em silêncio".

\section{Segundo ANTÔNIO SCARANCE FERNANDES ${ }^{115}$, que}

acompanha a maior parte da doutrina, o contraditório deve ser observado em todo o processo e não se fala em contraditório na atividade instrutória, mas em qualquer ato processual que possa envolver na formação do espírito do juiz.

Para o autor, a Constituição também é clara quando no art. $5^{\circ}$, inciso LV fala em processo. Dessa maneira, concorda com a maioria da doutrina que diz que o inquérito não se submete ao contraditório por ser procedimento realizado por autoridade administrativa.

Dessa forma, também concorda ANTÔNIO MAGALHÃES GOMES FILHO ${ }^{116}$ ao dizer que:

“(...) como a intervenção da acusação e da defesa é praticamente impossível nessa fase, especialmente se considerada a rotina da atividade policial, que certamente a transformaria numa mera formalidade, a solução que se vê, para o atendimento da garantia do contraditório, seria a impossibilidade de utilização dos dados obtidos nessa fase inquisitorial como prova (...)".

A efetiva participação do sujeito em termos de contraditório vai ser materializada integralmente na atividade processual, de forma que os autos de investigação deveriam estar separados da ação penal para evitar que a imparcialidade do juiz sofra influência da atividade discricionária da atividade policial a qual não observou a participação do então acusado.

A parte da doutrina que fala sobre a inexistência do principio do contraditório, ou pelo menos de um contraditório mitigado na fase investigativa devido à natureza e finalidade do procedimento, confirma, mesmo assim, a posição do indiciado como sujeito de direitos e garantias e não mais objeto puramente investigado.

\footnotetext{
${ }^{115}$ FERNANDES, Antônio Scarance. Op. cit., 56-57 p.

${ }^{116}$ GOMES FILHO, Antônio Magalhães (2). Op. cit., 145 p.
} 
FAUZI HASSAN CHOUK ${ }^{117}$ também entende que o indiciado não é considerado acusado e a ele não foi formalizada qualquer imputação delituosa, sendo que a verdadeira relação processual será instaurada quando a acusação for deflagrada formalmente pelo titular da ação penal e aceita pelo órgão jurisdicional. Ocorrido isto, estaremos diante da efetiva possibilidade de aplicação do princípio do contraditório como garantia do devido processo legal.

\subsubsection{Contraditório e Prova Penal}

O contraditório é garantia constitucional das partes no processo, mas antes de tudo é garantia da jurisdição, pois como adverte ADA PELLEGRINI GRINOVER ${ }^{118}$ :

“(...) porque se de um lado, é interesse dos litigantes a efetiva e plena possibilidade de sustentarem suas razões, de produzirem suas provas, de influírem concretamente sobre a formação do convencimento do juiz; do outro lado, essa efetiva e plena possibilidade constitui a própria garantia da regularidade do processo, da imparcialidade do juiz, da justiça das decisões".

A fase de instrução probatória é aquela que reclama pela efetiva participação das partes em contraditório, já que a iniciativa e a verificação dos atos probatórios são realizadas pelas partes e asseguradas pelo juiz ${ }^{119}$. Dessa forma, o princípio do contraditório obriga a observação de que às partes é dado o direito à prova ou direito de exclusão de prova (no caso de provas ilícitas, por exemplo).

Esse processo assegurado pelas garantias constitucionais exige uma intensa colaboração entre as partes e o juiz através de uma estrutura dialética do processo. Essa estrutura de cooperação também depende da atuação do juiz que deve exercer seus poderes na busca pela igualdade material entre a acusação e a defesa.

O princípio do contraditório emana do direito de defesa e nada mais é que o direito à informação dos atos realizados no processo e o direito à

\footnotetext{
${ }^{117}$ CHOUKR, Fauzi Hassan. Op. cit., 128-130 p.

${ }^{118}$ GRINOVER, Ada Pellegrini. Op. cit., 2 p.

${ }^{119}$ GOMES FILHO, Antônio Magalhães (2). Op. cit., 139-140 p.
} 
efetiva reação do interessado em determinar no convencimento do juiz. Portanto, como parte integrante do direito de ação e defesa, o contraditório exige que o juiz verifique se as partes atuam em igualdade de armas (par condicio), para desse modo, estimular a real participação das partes no contraditório na justaposição do devido processo legal ${ }^{120}$.

Conforme diz GLAUCO GIOSTRA em citação feita por ANTÔNIO MAGALHÃES COMES FILHO ${ }^{121}$ :

"Essa participação ativa dos interessados no provimento pode ocorrer de várias formas: preventivamente, quando se instaura o contraditório para debater a oportunidade de realizar determinado ato; concomitantemente, quando se manifesta através de atuação na própria prática do ato; ou, ainda, posteriormente, quando consiste em manifestação subseqüente ao ato, como, por exemplo, na discussão sobre o valor de uma prova já produzida".

É conferido às partes o direito de discutir sobre a forma de admissão da prova introduzida no processo, se manifestar sobre a legalidade das provas já produzidas, terem oportunidade de participar de todos os atos de composição das provas e por fim, questionar os resultados dos procedimentos de valoração das provas ${ }^{122}$.

Estimular a efetiva participação das partes na produção de provas e invocação de suas razões é dar efetividade ao principio do contraditório em um processo penal com a natureza de mínima disponibilidade. Os poderes cedidos ao juiz para que verifique o equilíbrio das situações entre defesa e acusação não afeta a sua imparcialidade no processo, ao contrário, apenas a mantém, já que as provas e alegações serão produzidas em situações de igualdade material em efetivo contraditório.

Como conseqüência do principio do contraditório deve o juiz garantir o direito à prova e às atividades instrutórias e valorar seu livre

\footnotetext{
120 “Assim sendo, o contraditório não se identifica com a igualdade estática, puramente formal, das partes no processo; não exprime a simples exigência de que os sujeitos possam agir em plano de paridade; nem determina ao juiz o mero dever de levar em conta a atividade de ambos, permitindo que façam ou até que deixem de fazer alguma coisa. O contraditório, como contraposição dialética paritária e forma organizada de cooperação no processo, constitui o resultado da moderna concepção da relação jurídica processual, da qual emerge o conceito de par condicio, ou igualdade de armas". GRINOVER, Ada Pellegrini. Op. cit., 7p.

${ }^{121}$ GIOSTRA, Glauco. Contraddittorio (principio Del), in Enciclopédia giuridica Treccani, Roma, Treccaci, 1988, v. VIII, p. 1. In: GOMES FILHO, Antônio Magalhães. Op. cit., 138-139 p.

${ }^{122}$ GOMES FILHO. Antônio Magalhães. Op. cit., 147-148 p.
} 
convencimento com base nas provas colhidas em juízo ${ }^{123}$, em contraditório e em sua presença, conforme o artigo 155 do novo Código de Processo Penal (Lei n. 11.690/08):

"O juiz formará sua convicção pela livre apreciação da prova produzida em contraditório judicial, não podendo fundamentar sua decisão exclusivamente nos elementos informativos colhidos na investigação, ressalvadas as provas cautelares, não repetíveis e antecipadas".

Esse momento de busca da verdade é o centro do processo dialético onde as provas deverão ser alegadas e contestadas pelas partes e motivadamente rejeitadas ou aceitas pelo juiz que equilibrará a efetiva participação dos interessados.

A presença das partes e do juiz é essencial à plena garantia ao contraditório e condição de validade das provas aptas a estimular seu livre convencimento. Não apenas o direito à prova permite que o interessado produza os meios que representem a verdade dos fatos, mas exige que elas sejam submetidas à valoração pelo juiz natural ${ }^{124}$.

Não serão consideradas provas, portanto, aquelas que forem produzidas sem a presença das partes e do juiz ${ }^{125}$ e sem o efetivo contraditório, ressalvadas as provas cautelares, não repetíveis e antecipadas.

Desse modo, as provas produzidas no inquérito policial não são provas em sentido técnico, mas sim informações que serão utilizadas no convencimento do autor da ação penal para efeitos de oferecimento de denúncia. De toda forma, as alegações do autor da ação penal, baseadas nos elementos de informação produzidos em sede de inquérito policial, deverão ser provadas em juízo, ou seja, perante as partes processuais e o juiz natural

\footnotetext{
123 "Obviamente, alguns atos serão aparentemente repetidos, mas não se trata de uma repetição em sentido jurídico, senão uma verdadeira produção, pois a única prova válida para a sentença é a produzida em juízo, com todas as garantias. Logo, só existe repetição se a mesma prova for produzida duas vezes ao longo do processo." LOPES JUNIOR, Aury. Op. cit., 110 p.

${ }_{124}^{124}$ GRINOVER, Ada Pellegrini. Op. cit., 22 p.

125 "É por essa interligação entre os princípios do juiz natural e do contraditório, que a exigência de que este seja instituído perante o juiz da causa é rigorosamente cumprida: tanto assim que, ainda que a prova seja produzida com a participação das partes, a ausência do juiz natural impossibilita a convalidação do vicio. É o que doutrina e jurisprudência denominam de impossibilidade de integração extrajudicial do contraditório". Ibid. 23p.
} 
da causa, em contraditório, sendo que as partes devem estar em condições efetivas de participar do debate.

\section{ANTONIO MAGALHÃES GOMES FILHO ${ }^{126}$ conclui que o} contraditório é condição de existência das provas e, por isso, as informações colhidas no inquérito policial jamais poderão ser utilizados pelo juiz na decisão final:

“(...) o desrespeito à contraditoriedade atinge a própria essência da prova considerada na decisão; aqui não se tem uma prova simplesmente irregular, mas, na verdade, uma não-prova, ato sem a mínima aptidão para fundar o raciocínio judicial".

\subsubsection{Contraditório e Juiz}

O juiz estará vinculado à participação das partes na instrução probatória, sendo que a apreciação das provas, ao contrário do sistema de provas legais, submete-se ao livre convencimento motivado desse julgador.

O juiz tem a obrigação de analisar todas as $\operatorname{provas}^{127}$ produzidas e fundamentar sua decisão no convencimento que elas foram capazes de produzir, dizendo os motivos que o levaram a rejeitar e/ou aceitar tais provas.

O juiz não tem a faculdade de observar o contraditório ${ }^{128}$, é dever do juiz no processo estimular a participação das partes e funcionar como sujeito ativo nessa função de condução do processo, devendo garantir os direitos fundamentais da jurisdição e das partes.

O magistrado tem poder para criticar e escolher o material produzido no processo para formar sua decisão, mas obrigatoriamente, estará limitado à motivação da sua convicção. A motivação é, antes de tudo, forma de controle dos atos dos membros do poder público e forma de legitimidade das decisões judiciais.

\footnotetext{
${ }^{126}$ GOMES FILHO, Antônio Magalhães (2). Op. cit., 169-170 p.

127 "Isso tudo, de resto, nada mais representa do que o principio geral de que o processo em contraditório não se esgota no direito à prova e à sustentação dos argumentos das partes, indicando ainda a exigência de o juiz valorar atentamente as atividades instrutórias e seus resultados". Ibid. 33 p.

${ }^{128}$ DINAMARCO, Cândido Rangel. Op. cit., 130-132 p.
} 
ANTÔNIO MAGALHÃES GOMES FILHO ${ }^{129}$ aponta o livre convencimento do juiz como uma atividade que envolve liberdade $\mathrm{e}$ responsabilidade:

“(...) na motivação devem estar explicitados todos os passos percorridos pelo magistrado para chegar à conclusão, representando, por isso, o ponto de referência obrigatório para a verificação da imparcialidade, do atendimento às prescrições legais e do efetivo exame das questões suscitadas no processo pelas partes (...) é por meio dela que será possível distinguir a decisão arbitrária, fruto exclusivo do poder, daquela amparada pela prova capaz de superar a presunção de inocência do acusado, ou seja, resultante de um saber; só através da indicação dos motivos da decisão será viável constatar a existência de um nexo entre o convencimento e as provas produzidas".

A motivação da decisão pelo juiz será essencial para verificar se as provas que lhe serviram como parâmetro ao seu livre convencimento foram, necessariamente, produzidas em contraditório. $\mathrm{O}$ direito ao contraditório se estende às partes como direito à prova e, por fim, como direito à motivação das decisões ${ }^{130}$.

Conforme art. 93, inciso IX da Constituição da República, a motivação das decisões é garantia das partes no processo e garantia da própria jurisdição $^{131}$ :

"todos os julgamentos dos órgãos do Pode Judiciário serão públicos, e fundamentadas todas as decisões, sob pena de nulidade, podendo a lei limitar a presença, em determinados atos, às próprias partes e a seus advogados, ou somente a estes, em casos nos quais a preservação do direito à intimidade do interessado no sigilo não prejudique o interesse público à informação".

\section{Portanto, como diz ANTÔNIO SCARANCE FERNANDES ${ }^{132}$ :}

"Não há dúvida que a existência de motivação abrange todas as decisões relevantes do processo, definitivas ou interlocutórias, principalmente quando estas afetem direitos individuais (...). A falta de motivação da decisão interlocutória ou da sentença é causa de nulidade absoluta, porque há ofensa a importante garantia do devido processo legal e a preceito constitucional".

\footnotetext{
${ }^{129}$ GOMES FILHO, Antônio Magalhães (2). Op. cit., 163-165 p.

${ }^{130}$ Ibid. $165-166$ p.

${ }^{131}$ FERNANDES, Antônio Scarance. Op. cit., 119 p.

${ }^{132}$ Ibid. 121-122 p.
} 


\subsection{Provas Colhidas no Inquérito Policial}

\subsubsection{Elementos de Informação}

Os elementos de informação assim são chamados porque foram colhidos durante a fase de investigação e se referem a uma mera hipótese, servindo para formar um juízo de probabilidade e não observando a aplicação do principio do contraditório, da publicidade e da imediação ${ }^{133}$.

Eles não tem o condão de provar a culpabilidade, mas justificam a admissibilidade da denúncia pelo autor da ação penal e justificam medidas cautelares e outras restrições durante a fase pré-processual ${ }^{134}$.

Também chamados de atos de investigação, os elementos informativos tem seu valor probatório extremamente limitado, já que não foram colhidos em uma estrutura dialética e cooperatória, sendo que a verdade probatória é aquela produzida perante toda essa estrutura acusatória $^{135}$.

É importante dizer que o artigo 12 do Código do Processo Penal ${ }^{136}$ não atribui valor aos elementos colhidos na investigação policial. $O$ objetivo do legislador, em conformidade com a Constituição Federal de 1988, foi dizer que o inquérito policial deve acompanhar a denúncia ou a queixa para permitir ao juízo decidir a admissibilidade ou não da acusação, ou seja, decidir pelo início da ação penal ou pelo arquivamento do inquérito policial.

\footnotetext{
133 “O principio da imediação está vinculado ao da oralidade e dirige especialmente a recepção da prova. Significa que o juiz deve atentar a estes dois postulados: a) utilização imediata dos meios probatórios (principio da imediação em sentido subjetivo ou formal); b) que se deve utilizar os meios de prova imediatos (princípio de imediação em sentido objetivo ou material)". LOPES JUNIOR, Aury. Op. cit., 120 p.

${ }_{134}^{134}$ Ibid. 137 p.

${ }^{135}$ Em seu livro, Aury Lopes Jr. cita Carnelutti (Derecho Procesal Civil y Penal, p. 340) no que diz respeito à eficácia restrita das provas produzidas durante a investigação. "Como explica Carnelutti, a eficácia das provas produzidas no curso da investigação devem limitar-se aos fins da investigação; tais provas podem servir somente para a decisão do MP sobre o ponto de se deve ou não pedir autorização do juiz para castigar; não, em câmbio, para a decisão do juiz de se a autorização deve dar-se ou não, mas os elementos de convicção do juiz não podem ser proporcionados senão pelo que ocorreu ante ele, pelo que ele viu e ouviu". Ibid. 138p.

136 Art. 12 do CPP: "O inquérito policial acompanhará a denúncia ou queixa, sempre que servir de base a uma ou outra".
} 
Infelizmente, não é o que acontece no Judiciário brasileiro. Os autos do inquérito que contém estas informações não sujeitas ao contraditório são anexados à peça de acusação e são avaliados, mesmo que inconscientemente, pelo juiz da causa que, erroneamente, as utiliza tornando a atividade jurisdicional mero desdobramento da atividade policial.

Por isso, tanta ênfase na proposta de revisão da estrutura utilizada que propõe a cisão física dos autos de investigação da peça de acusação e a existência de um órgão jurisdicional somente para questões de admissibilidade da denúncia.

O objetivo é garantir que a valorização das provas recairá somente sobre os atos praticados na fase processual e que exista um órgão jurisdicional exclusivo para análise os incidentes da fase investigativa e repressor das ilegalidades. É o que ocorre na estrutura penal italiana ${ }^{137}$.

A falta de valor probatório destes elementos de informação se justifica pela ausência de contraditório, ou seja, pela ausência de participação ativa das partes na sua construção.

Sendo assim, o valor destes atos termina com a admissão da denúncia e apenas as provas judiciais serão válidas, pois a pretensão é pela prova formalmente colhida no curso do processo penal.

\subsubsection{Produção Antecipada de Provas}

O incidente de produção antecipada de provas ainda na fase préprocessual ocorre devido à própria natureza de certos elementos de informação que correm o risco de dispersão e a não possibilidade de serem repetidos durante o processo. Essa prova tem valor probatório na sentença, apesar de colhida na fase de investigação.

\footnotetext{
137 "Elogiável, sem dúvida, a técnica adotada pelo sistema italiano, de eliminar dos autos que formarão o processo penal todas as peças da investigação preliminar (indagine preliminare), com exceção do corpo de delito e das antecipadas, produzidas no respectivo incidente probatório. Como explicam Dalia e Ferraioli, um dos motivos da clara distinção entre o procedimento per le indagini preliminari e o processo é exatamente evitar a contaminação do juiz pelos elementos obtidos na fase pré-processual". LOPES JUNIOR, Aury. Op. cit., 140 p.
} 
À produção antecipada de provas é aplicado o conjunto mínimo de garantias aplicáveis ao processo e, por isso, alguns requisitos mínimos são necessários para que seu valor probatório seja alcançado.

Em primeiro lugar, esse incidente pressupõe que as provas sejam indispensáveis para a sentença e, em segundo lugar, que a sua repetição em juízo durante a fase processual seja impossível por razões de perecimento e dispersão da prova ${ }^{138}$ como é o caso, por exemplo, do exame de corpo de delito, algumas perícias ${ }^{139}$ e até depoimentos de testemunhas ${ }^{140}$.

Portanto, o perigo de comprometimento dos resultados do processo e da função judiciária sobre a fonte de prova, autoriza, excepcionalmente, uma restrição ao pleno exercício do contraditório, que será exercido posteriormente pelas partes, ou, quando a relação processual já está instaurada, o incidente permite o pleno exercício do contraditório ${ }^{141}$.

Segundo ADA PELLEGRINI GRINOVER, quanto às provas cautelares, não repetíveis e antecipadas, o objetivo é "assegurar o resultado da prova, ainda na primeira fase da persecutio criminis, ou seja, no inquérito policial ${ }^{142, "}$. O contraditório é observado posteriormente à colheita das provas, pois impossível é dar efetividade a possibilidade de informação e reação quanto a elas devido à natureza dessas provas ${ }^{143}$.

\section{ANTÔNIO SCARANCE FERNANDES ${ }^{144}$ assim também se} declara a respeito:

\footnotetext{
${ }^{138}$ Ibid. 142 p.

139 Art. $159, \S 3^{\circ}$, do CPP efetiva plenamente o direito ao contraditório e à ampla defesa: "Serão facultadas ao Ministério Público, ao assistente de acusação, ao ofendido, ao querelante e ao acusado a formulação de quesitos e indicação de assistente técnico". $\S 3^{\circ}$ acrescentado pela Lei $\mathrm{n}$. 11.690, de 9 de junho de 2008 (DOU de 10-6-2008, em vigor 60 dias após a publicação).

${ }^{140}$ Art. 225, do CPP: "Se qualquer testemunha houver de ausentar-se, ou, por enfermidade ou por velhice, inspirar receio de que ao mesmo tempo da instrução criminal já não exista, o juiz poderá, de ofício ou a requerimento das partes, tomar-lhe antecipadamente o depoimento".

${ }^{141}$ GOMES FILHO, Antônio Magalhães. Prova, Lei no 11.690, de 09.06.2008, In: MOURA, Maria Thereza Rocha de Assis et al.. As Reformas no processo penal: as novas leis de 2008 e os projetos de reforma. São Paulo: Revista dos Tribunais, 2009. 252-254p.

142 GRINOVER, Ada Pellegrini. Op. cit., 29p.

143 "O periculum in mora e o fumus boni iuris autorizam e exigem mesmo a antecipação dessas provas, ad perpetuam rei memoriam. Mesmo com relação a tais cautelas, contudo, não se pode olvidar o principio do contraditório, simplesmente deslocado para momentos sucessivos". Ibid. $29 \mathrm{p}$.

${ }^{144}$ FERNANDES, Antônio Scarance. Op. cit., 60 p.
} 
"Entre nós, as medidas cautelares são, em regra, determinadas sem audiência do titular do direito restringido, de ofício ou em atenção a requerimento do Ministério Público, do ofendido ou representação da autoridade policial. As perícias são realizadas também sem participação do investigado ou de seu advogado. A observância do contraditório, nesses casos é feita depois, dando-se oportunidade ao suspeito ou réu de contestar a providência cautelar ou de combater, no processo, a prova pericial realizada no inquérito. Fala-se em contraditório diferido ou postergado".

\subsection{Críticas ao Modelo Atual}

\subsubsection{Ausência de um Juiz exclusivo para a Investigação}

Nossa legislação, diferente de muitos modelos adotados internacionalmente, como o italiano, não prevê um juiz exclusivo para a fase de investigação, nem um juiz de garantias exclusivo neste momento pré-processual.

Além disso, o mesmo juiz que teve contato com o inquérito nessa fase (no caso de medidas cautelares) será o mesmo que irá julgar a causa e emitir uma decisão final.

Essas observações são feitas por FAUZI HASSAN CHOUKR ${ }^{145}$. Segundo o autor:

“A principal conseqüência do nosso sistema nesse ponto é a de permitir que o juiz que tem contato com os autos de inquérito para qualquer ato (como nas "concessões" de prazo, por exemplo) possa ser indesejavelmente influenciado por tudo aquilo que foi produzido previamente à ação penal, deixando aflorar essa influência não somente no juízo de admissibilidade da inicial, mas, sobretudo, procurando incorporar ao seu convencimento quanto ao mérito elementos de informação que não teriam essa finalidade".

Segue o autor dizendo que uma reforma estrutural do nosso sistema é necessária em busca de um juiz garantidor de direitos fundamentais que seja exclusivo para esta primeira fase, e de um juiz exclusivo para a fase processual, responsável pelo julgamento do mérito.

\footnotetext{
${ }^{145}$ CHOUKR, Fauzi Hassan. Op. cit., 93 p.
} 


\subsubsection{Influência da Fase Investigativa na Judicial}

Os elementos de informação não submetidos sob o crivo do contraditório e as medidas cautelares submetidas a um contraditório diferido são colhidos durante a fase investigativa e acabam influenciando na decisão jurisdicional.

A solução trazida por FAUZI HASSAN CHOUKR ${ }^{146}$ é afastar os primeiros elementos do conhecimento do juiz da causa através da separação física do inquérito policial e jurisdicionalizar a fase das medidas cautelares para permitir o contraditório:

"A situação seria diferente se, num primeiro momento, tivéssemos uma saudável separação dos autos da investigação dos definitivos e, ainda, se, dentro de uma reestruturação do sistema judiciário, tivéssemos um juiz para atuar no primeiro contato com a notícia da apuração do delito diverso daquele que julgasse o mérito da causa".

Nesse sentido, AURY LOPES JUNIOR também cita como exemplo o Código de Processo Penal Italiano que separou dos autos da ação penal os autos de investigações preliminares, com exceção das provas acautelatórias, produzidas na fase investigação sob contraditório:

"Elogiável, sem dúvida, a técnica adotada pelo sistema italiano (...). Para evitar a contaminação, o ideal é adotar o sistema de eliminação do processo dos autos de investigação, excetuando-se as provas técnicas irrepetíveis e a produzida no respectivo incidente probatório".

Uma última solucão encontrada para que os elementos de informação, à luz do contraditório, pudessem ser manipulados e valorados pelo juiz seria através do sistema de instrução preliminar judicial.

\footnotetext{
${ }^{146}$ Ibid. 131-139 p.
} 


\section{Capítulo 3 - A Reforma do Código de Processo Penal}

\subsection{Código Modelo de Processo Penal para Ibero - América ${ }^{147}$}

\subsubsection{A proposta}

A proposta deste código modelo é criar uma unidade legislativa entre as comunidades culturais homogêneas ibero-americanas para estimular possíveis reformas de códigos nacionais que ainda contém resquícios do inquisitorial ismo e não atendem às políticas jurídicas e sociais do indivíduo de modo satisfatório. Porém, surgiram diversas manifestações contrárias dos mais diversos setores jurídicos, ainda arraigados ao modelo anterior, fazendo com que as reformas permaneçam lentas e graduais.

A elaboração técnica foi realizada por alguns juristas argentinos e brasileiros colaboradores, entre eles Julio Maier e Ada Pellegrini Grinover, tendo como inspiração: as propostas de inúmeros juristas, o Código de Processo Penal da Alemanha Federal e, sobretudo, as declarações e pactos internacionais (Declaração Universal de Direitos Humanos e o Pacto de São José da Costa Rica, por exemplo).

$\mathrm{O}$ projeto final foi apresentado às "XI Jornadas Ibero-americanas de Direito Processual", no Rio de Janeiro, em 1988 e tem como principais destaques: a valorização e o respeito à dignidade do acusado ou suspeito, o relevo ao devido processo penal com todas as garantias e direitos fundamentais $^{148}$, a eleição do modelo acusatório como sistema de processo

147 GRINOVER, Ada Pellegrini. O Processo em evolução. $2^{\mathrm{a}}$ ed. Rio de Janeiro: Forense Universitária, 1998. 202-241 p.

148 A disposição n. 1. do Código Modelo de Processo Penal para Ibero-América estabelece, em termos gerais, a garantia ao indivíduo ao devido processo legal e aos princípios individuais fundamentais. Disposição 1. Juicio previo. Nadie podrá ser condenado, penado o sometido a uma medida de seguridad y corrección, sino después de una sentencia firme, obtenida por um procedimiento regular, llevado a cabo conforme a las disposiciones de este Código, com observancia estricta de las garantias previstas para las personas, y de las facultades y los derechos del imputado. La inobservancia de una regla de garantia establecida en favor del imputado no se podrá hacer valer en su perjuicio. As disposições seguintes $(2,3,4$ e 5$)$ fazem referência ao princípio do Juiz Natural, à presunção de inocência, ao princípio da vedação pro societate, à 
penal ${ }^{149}$, possibilitando que vários ordenamentos da América Espanhola almejassem uma estrutura acusatória.

\subsubsection{A disciplina das provas no Código Modelo}

À semelhança do Código de Processo Penal Italiano, os elementos de informação colhidos no inquérito policial não tem valor de prova e sua função está ligada, exclusivamente, a formar a opinio delicti do Ministério Público na instauração da ação penal, ressalvada a sua utilização no incidente de antecipação de provas, realizado sob o crivo do contraditório.

Além disso, os elementos de informação coletados no inquérito são eliminados dos autos da ação penal, com exceção das provas irrepetíveis e das antecipadas, dada a ausência de valor probatório e a necessária garantia da imparcialidade do juiz.

As medidas cautelares são realizadas por um juízo de investigações prévias em que o juiz que as determina não será o mesmo que julga o mérito da causa, evitando assim qualquer contato com dados coletados no inquérito. Ainda nesse sentido, o juiz que verifica as questões de admissibilidade ou arquivamento de denúncia realizada pelo Ministério

indisponibilidade e à efetiva defesa técnica do imputado ou acusado e ao direito do individuo de participação efetiva em todos os procedimentos, inclusive os preliminares em que já se encontra como possível autor de uma infração penal. Código Procesal Penal Modelo para Ibero-America.

149 "Traçadas em grandes linhas, assim podem ser sintetizadas as características fundamentais do Código: a) a ênfase ao respeito à dignidade do suspeito ou acusado, no pleno acolhimento dos princípios do devido processo legal; b) a adoção do modelo acusatório, com a nítida separação entre as funções de julgar, acusar e defender; c) a transparência dos procedimentos, gerada por um juízo público e oral e pela presença ininterrupta dos protagonistas do processo, juízo este em cujo transcurso se incorpora o único material probatório que pode servir de base à sentença; d) a busca de eficiência do processo, entendida, de um lado, como eficiência na persecução penal e, do outro, como efetividade das garantias processuais; e) a desburocratização da organização judiciária, implicando a luta contra a delegação de funções e a personalização do exercício da função jurisdicional, bem como, na medida do possível, a horizontalização dos tribunais, com a preferência pelos controles externos; f) a participação popular na administração da justiça, consoante os sistemas próprios dos regimes constitucionais; g) diversos mecanismos de seleção de casos, com a mitigação dos princípios da obrigatoriedade e da indisponibilidade, pela adoção da oportunidade regulada por lei e sujeita ao controle jurisdicional; a possibilidade de suspensão condicional do processo, pelo período de provas; os procedimentos abreviados para as infrações menores; tudo de modo a excluir rapidamente do sistema uma grande porcentagem de casos; h) $a$ globalidade da reforma, porquanto o código supõe uma nova organização judiciária, com a necessária reestruturação, a nível dos países interessados, dos órgãos da administração da justiça penal (tribunais, Ministério Público, defensorias, serviços da justiça)”. GRINOVER, Ada Pellegrini. O Processo em evolução. $2^{a}$ ed. Rio de Janeiro: Forense Universitária, 1998. 222 p. 
Público é diverso do juiz da causa, evitando mais uma vez, qualquer comprometimento da sua imparcialidade.

A prova está intimamente ligada ao princípio do contraditório ${ }^{150}$, sendo que somente esta terá valor probatório na sentença condenatória. Desta forma, não há possibilidade de qualquer utilização dos dados de informação colhidos na fase de investigação uma vez que não tem status de prova.

\subsection{A Reforma do Código de Processo Penal}

\subsubsection{O anteprojeto de 2001}

O Ministro da Justiça José Carlos Dias pela Portaria nº 61, de 20 de janeiro de 2000 constituiu nova comissão ${ }^{151}$ presidida pela Jurista e Professora Ada Pellegrini Grinover para apresentar propostas de reforma ao Código de Processo Penal.

A Comissão deveria analisar os projetos da comissão anterior, de 1994, mas decidiu propor uma reforma parcial, ou seja, referente a alguns temas, em contrapartida a uma reforma total, pois considerou que esta seria impossível devido às dificuldades criadas no próprio Congresso Nacional.

A comissão presidida por Ada Pellegrini Grinover usou como referência à produção dos anteprojetos sobre a reforma do Código de Processo Penal de 1941, principalmente, o Código Modelo de Processo Penal para Ibero - América de 1988.

\footnotetext{
${ }^{150} \mathrm{O}$ dispositivo n. 148 do Código Modelo Ibero-americano se refere à inadmissibilidade de provas obtidas por meios ilícitos no processo e ao princípio do contraditório, garantia fundamental. Dispositivo n. 148. (...) Son inadmisibles, en especial, los elementos de prueba obtenidos por un médio prohibido, tales como la tortura, la indebida intromisión en la intimidad del demicilio, la correspondencia, las comunicaciones, los papeles y los archivos privados (...). Además de los médios de prueba previstos en este capítulo, se podrá utilizar otros distintos, siempre que no supriman las garantías y faculdades de las personas reglamentadas en este Código o afecten el sistema institucional. La forma de su incorporación al procedimiento se adecuará al médio de prueba más análogo, de los previstos, em lo posible. Código Procesal Penal Modelo para IberoAmerica.

${ }^{151}$ A comissão era formada por juristas do Instituto Brasileiro de Direito Processual, entre eles, Ada Pellegrini Grinover, Petrônio Calmon Filho, Antônio Magalhães Gomes Filho, Antônio Scarance Fernandes, Luiz Flávio Gomes, Miguel Reale Júnior, Nilzardo Carneiro Leão, René Ariel Dotti (substituído por Rui Stoco), Rogério Lauria Tucci e Sidnei Beneti.
} 
Sendo assim, a comissão apresentou sete anteprojetos amplamente discutidos na comunidade jurídica, convertidos em Lei e que alteraram diversos dispositivos do Decreto-Lei $n^{\circ}$ 3.689, de 3 de outubro de 1941, encaminhados ao Congresso Nacional.

\subsection{2. $O$ anteprojeto na disciplina das provas}

O anteprojeto (PL 4.205/01) sobre provas, convertido na Lei 11.690/08, buscava: a simplificação das provas periciais, uma efetiva cooperação das partes do processo na produção das provas ${ }^{152}$, um procedimento diferente na colheita da prova testemunhal, a inadmissibilidade das provas obtidas ilicitamente e a cisão física do inquérito policial dos autos do processo judicial após o recebimento da denúncia, mas esta última proposta não vingou.

a) Provas Periciais. $\mathrm{O} \S 1^{\mathrm{o}}$ do art. $6^{\mathrm{o} 153}$ do anteprojeto previa a possibilidade de participação das partes em contraditório na realização das provas periciais durante a fase de inquérito policial. Segundo PETRÔNIO CALMON FILHO ${ }^{154}$ :

“O denominado 'contraditório diferido' é um paliativo que não representa concretamente a garantia constitucional e deve ser evitado, sempre que possível, para que prevaleça o 'verdadeiro contraditório', existente apenas quando às partes é dada a oportunidade de participação antes, durante e após a prática de cada ato".

Porém, esta previsão foi modificada por duas vezes, a primeira no projeto final que não mais permitia a possibilidade de contraditório no exame de corpo de delito e nas outras perícias. A segunda modificação foi

\footnotetext{
${ }^{152}$ Como, por exemplo, a nomeação pelo juiz de um perito oficial, passível de substituição por duas pessoas idôneas, preferencialmente com habilitação técnica e o oferecimento de quesitos e indicação de assistente técnico. MALAN, Diogo Rudge. Palestra sobre Inovações nas provas (Lei 11.690/08), In Seminário “A Reforma do Código de Processo Penal”. Rio de Janeiro. 2008. 3p.

${ }^{153}$ Art. $6^{\circ}, \S 1^{\circ}$ : Instaurado inquérito, as diligências previstas nos incisos V e VII deverão ser realizadas com prévia ciência do Ministério Público e intimação do ofendido e do investigado.

${ }^{154}$ CALMON FILHO, Petrônio. A investigação criminal na reforma do código de processo penal: agilidade e transparência, In: Revista Brasileira de Ciências Criminais. São Paulo, n. 34, abr./jun. $2001.73 \mathrm{p}$.
} 
simplesmente a supressão do $\S 1^{\circ}$, não existindo mais previsão expressa do contraditório na fase de investigação ${ }^{155}$.

b) Elementos de informação. ADA PELLEGRINI GRINOVER ${ }^{156}$ expõe a necessária função estrita dos elementos de informação colhidos no inquérito policial, dizendo que cumprem o dever de formação da opinio delicti do Ministério Público e de admissão de medidas cautelares pelo juiz:

"não podendo esses elementos servir de fundamento para a sentença, com exceção das provas produzidas cautelarmente ou irrepetíveis, sobre as quais se estabelecerá o contraditório posterior".

Nesse sentido, PETRONIO CALMON FILHO $^{157}$ comenta a proposta do anteprojeto no artigo $7^{\circ}$, seu parágrafo único e sua vinculação aos artigos 155 e 399 do CPP/08.

O parágrafo único do art. $7^{\circ}$ diz que "os elementos informativos da investigação criminal não poderão constituir fundamento da sentença, ressalvadas as provas irrepetíveis cautelares, que serão submetidos ao contraditório diferido". Guardava sintonia com o art. 155, mas foi suprimido e o Congresso adicionou o advérbio "exclusivamente" à redação do art. 155, o que acabou por permitir a introdução dos dados colhidos no inquérito na sentença.

Do mesmo modo, foi afastada a norma do art. 399 do anteprojeto que previa a cisão física do inquérito policial depois de recebida a denúncia pelo juiz e impedia que o mesmo juiz que tivesse tomado contato com os elementos do inquérito pudesse julgar a causa. A proposta não foi aceita porque, segundo PETRÔNIO CALMON FILHO “a proposta se mostrou inovadora em excesso".

\footnotetext{
${ }^{155} \mathrm{Com}$ a retirada do $\S 1^{\circ}$ do art. $6^{\circ}$, o dispositivo, também novo, $159, \S 3^{\circ}$ perdeu sua eficácia em sede de inquérito policial, já que a nomeação de assistente técnico pelas partes e a formulação de quesitos somente poderá ser feita após a realização da perícia e no processo, conforme será visto abaixo no item sobre os dispositivos reformados. Diante da falta de previsão legal do contraditório na investigação, as partes só exercerão o contraditório em juízo.

${ }^{156}$ GRINOVER, Ada Pellegrini. Introdução: A reforma do processo penal, In: Revista Brasileira de Ciências Criminais. São Paulo, n. 33, jan./mar.2001. 307 p.

${ }^{157}$ CALMON FILHO, Petrônio. A investigação criminal na reforma do código de processo penal: agilidade e transparência, In: Revista Brasileira de Ciências Criminais. São Paulo, n. 34, abr./jun. $2001.76 \mathrm{p}$.
} 


\subsection{Dispositivos reformados}

Art. 155. O juiz formará sua livre convicção pela livre apreciação da prova produzida e contraditório judicial, não podendo fundamentar sua decisão exclusivamente nos elementos informativos colhidos na investigação, ressalvadas as provas cautelares, não repetíveis e antecipadas.

Parágrafo único. Somente quanto ao estado de pessoas serão observadas as restrições estabelecidas na lei civil

\subsubsection{Livre convencimento do juiz}

Como se observa no novo dispositivo o objetivo da reforma é demarcar, expressamente, os limites quando à produção da prova ao que se chama livre convencimento do juiz, em contraposição ao antigo sistema de hierarquia das provas do sistema inquisitório em que cada prova tinha um valor estabelecido em lei.

O propósito da mudança é deixar claro que o juiz deve emitir sua decisão com base em uma discricionariedade de valor em relação às provas, respeitados os limites de racionalidade do juízo dos fatos, da participação das partes e a própria fundamentação da sua decisão. Como fala ANTÔNIO MAGALHÃES GOMES FILHO ${ }^{158}$, o livre convencimento do juiz é uma atividade que envolve liberdade e responsabilidade.

Ainda assim, LUIZ FLÁVIO GOMES ${ }^{159}$ faz importante ressalva contra qualquer poder ilimitado do juiz:

"A liberdade aqui prevista não é, nem deve implicar nunca, no arbítrio, merecendo limitações. Dentre tais limitações, destaca-se aquela que veda a produção da prova obtida por meios ilícitos, segundo expresso preceito constitucional (art. $5^{\circ}, \mathrm{LVI}$, da CF), (...). Ou a prova quanto ao estado de pessoas, para a qual não vigora qualquer liberdade em sua produção, na medida em que deve atender às restrições estabelecidas na lei civil ${ }^{160},(\ldots)$ ".

\footnotetext{
${ }^{158}$ GOMES FILHO, Antônio Magalhães. Direito à prova no processo penal. São Paulo: Revista dos Tribunais, 1997. $163 \mathrm{p}$.

${ }^{159}$ GOMES, Luiz Flávio. Op. cit., 269 p.

${ }^{160}$ GOMES, Luiz Flávio. Op. cit., 271-272. Quanto ao estado de pessoas, o autor diz que a prova produzida na lei civil prevalece sobre a criminal, pois jamais seria superada por esta prova. Um
} 
A nova redação do art. 155 limita estritamente o livre convencimento do juiz às provas produzidas em contraditório, aos elementos de informação do inquérito judicial e, excepcionalmente, às provas cautelares, antecipadas e irrepetíveis. Dessa forma, não há como motivar a sentença com base em outros critérios ${ }^{161}$.

\subsubsection{A utilização dos elementos informativos na sentença}

Embora o legislador tenha feito essa importante ressalva com relação às provas e sua vinculação ao contraditório e os elementos de informação, ele não acolheu a original redação do artigo 155 da Comissão e do Poder executivo que excluía qualquer tipo de apreciação jurisdicional dos elementos informativos colhidos no inquérito judicial para fundamentar a sentença.

$\mathrm{O}$ advérbio exclusivamente foi inserido pelo legislador e acabou impedindo que a formação do livre convencimento do juiz tomasse por base apenas as provas produzidas em contraditório judicial, sendo legítima a fundamentação da decisão com base nos elementos de informação, desde que existam também as provas produzidas em contraditório ${ }^{162}$ e que concorram com os elementos informativos.

LUIZ FLÁVIO GOMES ${ }^{163}$ também confirma a intenção do legislador da Lei 11. 690/08 em restringir o uso dos dados do inquérito

exemplo é a extinção da punibilidade do réu pela morte do agente (art. 107, I, do CP) que só poderá ser comprovada mediante a certidão de óbito do mesmo (art. 62 do CPP).

${ }^{161}$ GOMES FILHO, Antônio Magalhães (1). Op. cit., 248-249 p.

162 Antônio Magalhães Gomes Filho entende que a redação modificada pelo Congresso Nacional induz que a prova produzida em contraditório judicial seja convergente com os elementos informativos constantes no inquérito policial e, com isso, produzam o mesmo resultado. Conforme o exemplo demonstrado, "Pense-se, para exemplificar, na situação em que as informações do inquérito policial apontem para a ocorrência de um furto qualificado. Se as provas produzidas em contraditório judicial somente confirmarem a subtração, mas nada disserem sobre qualificadora, em relação a esse último fato não haverá convergência e, portanto, o juiz não poderá sobre ele formar o seu convencimento exclusivamente com base nas informações do procedimento investigatório". GOMES FILHO, Antônio. Op. cit., 252p.

${ }^{163}$ GOMES, Luiz Flávio. Op. cit., 269-270 p. 
colhidos sem observação do contraditório à confirmação em juízo e a não possibilidade de serem utilizados de forma isolada ${ }^{164}$ :

“(...) a prova extrajudicial isoladamente considerada, não se revela apta a fundamentar uma decisão. No entanto, não deve ser totalmente ignorada, podendo se agregar à prova produzida em juízo, servindo como mais um elemento na formação da convicção do julgador, sobretudo porque colhida, via de regra, de forma imediata, logo após a prática delituosa".

\section{Assim também entende ANDREY BORGES DE MENDONÇA ${ }^{165}$}

sobre a possibilidade de intromissão de dados colhidos no inquérito policial, desde que seja fundamentada a decisão e que as provas e os dados concorram para a mesma circunstância:

"A contrario sensu, é possível que sejam reputados na sentença condenatória elementos produzidos durante o inquérito policial, desde que apenas como reforço às provas produzidas em juízo (aqui sim em observância do contraditório). (...). Portanto, as provas produzidas durante o inquérito podem corroborar aquelas que foram produzidas em juízo, fortalecendo o panorama probatório e permitindo que se justifique a prolação de sentença condenatória".

\subsubsection{As provas cautelares e antecipadas}

A ressalva feita às provas cautelares, não repetíveis e antecipadas diz respeito à possibilidade de utilização das mesmas no processo judicial, mesmo sem a observação do contraditório a priori.

$\mathrm{O}$ que ocorre nesse caso é que num primeiro momento o contraditório é diferido e deslocado à fase processual. $\mathrm{O}$ deslocamento da participação das partes em contraditório é necessário devido à própria natureza dessas provas que podem perder a sua eficácia no tempo caso não sejam antecipadas.

ANTÔNIO MAGALHÃES GOMES FILHO ${ }^{\mathbf{1 6 6}}$ cita o motivo que leva a antecipação dessas provas à fase de investigação, mas faz citação quanto ao contraditório diferido que possibilitará às partes discutir sobre a legalidade e a validade destas provas:

\footnotetext{
${ }^{164}$ STF, HC 73. 338-RJ, Rel. Min. Celso de Mello, DJ 19.12.1996 confirmou que somente a prova produzida em juízo produz eficácia processual e faz referência a não possibilidade de uso isolado dos elementos de informação colhidos na fase de investigação para fundamentar sentença.

165 MENDONÇA, Andrey Borges de. Nova reforma do Código de Processo Penal: comentada artigo por artigo. São Paulo: Método, 2008. 154-157 p.

${ }^{166}$ GOMES FILHO, Antônio Magalhães (1). Op. cit., 252-253 p.
} 
"Como providências de natureza cautelar, somente admissíveis em caráter excepcional, estão sujeitas aos requisitos típicos do fumus boni iures - no caso, a relevância da prova que se pretende produzir antecipadamente - e do periculum in mora - caracterizado aqui pelo risco de que, ao tempo da instrução, a fonte de prova não mais exista ou não possa trazer as informações que interessam ao processo".

Importante destacar também é a diferença que o legislador atribuiu às provas cautelares e antecipadas. Embora a medida cautelar seja o meio utilizado para antecipar a prova, o legislador pretendeu fazer sobressair uma pequena diferença: de que existem atos de provas realizados sem a participação das partes em contraditório (provas cautelares) e situações em que a antecipação das provas acontece com a relação jurídica já instalada, o que pressupõe, desde já, a participação dos sujeitos processuais ${ }^{167}$.

A questão da utilização exclusiva dessas provas cautelares e antecipadas $^{168}$ para condenar o réu é bem levantada por ANDREY BORGES DE MENDONÇA ${ }^{\mathbf{1 6 9}}$. O autor diz que com relação às cautelares, isso será possível porque o contraditório é diferido para a fase processual e, da mesma forma, também ocorre nas provas antecipadas já que estas nascem sobre o contraditório e na presença das partes e do juiz.

\subsubsection{Provas "não repetíveis"}

\section{ANTÔNIO MAGALHÃES GOMES FILHO $^{170}$ faz importante}

referência quanto à inspiração do legislador da reforma ao Código de

\footnotetext{
${ }^{167}$ GOMES FILHO, Antônio Magalhães (1). Op. cit., 253 p. O autor cita o exemplo do art. 225 do Código de Processo Penal quando à antecipação de prova testemunhal que observa o contraditório: "Se qualquer testemunha houver de ausentar-se, ou, por enfermidade ou por velhice, inspirar receio de que ao tempo da instrução criminal já não exista, o juiz poderá, de ofício ou a requerimento de qualquer das partes, tomar-lhe antecipadamente o depoimento".

${ }^{168}$ MENDONÇA, Andrey Borges de. Op. cit., 158-160 p. O autor conceitua provas cautelares, antecipadas e não repetíveis: quanto às cautelares, o risco de perecimento da prova acaba deslocando o contraditório para um momento posterior, o que não fere a garantia; quanto às antecipadas, são aquelas que observam o contraditório e tem sua produção antecipada devido a questões de urgência e relevância. A ressalva que faz é sobre a necessária presença, nas duas provas, dos requisitos do fumus boni iuris e do periculum in mora.

${ }^{169}$ MENDONÇA, Andrey Borges de. Op. cit., 157-159 p.

${ }^{170}$ GOMES FILHO, Antônio Magalhães (1). Op. cit., 254-255 p. O autor esclarece que no sistema italiano prevalece a participação das partes em contraditório, na presença do juiz, no incidente de antecipação de provas e, caso exista a imprevisibilidade de fatos ou circunstâncias, o contraditório será diferido para a fase seguinte.
} 
Processo Penal Italiano para determinar a praticidade das provas não repetíveis:

"O legislador nacional inspirou-se aqui, claramente, em disposições do Código de Processo Italiano, de 1988, que autoriza a leitura, na fase de debates, de declarações prestadas anteriormente perante a Polícia Judiciária ou o MP, na investigação, ou diante do juiz, no curso da audiência preliminar, quando, por fatos ou circunstâncias imprevisíveis, tornou-se impossível a sua repetição (art. 512 do CPP italiano)".

Portanto, a previsibilidade de determinado fato ou circunstância é importante para determinar seu momento de produção. Caso não seja possível sua produção no processo ele será produzido sem o contraditório, sem prejudicar a garantia em um momento posterior. Mas, caso a prova possa ser repetida em juízo, ela deverá ser realizada no processo com a participação das partes em contraditório e na presença do juiz.

A ressalva feita sobre as provas não repetíveis e sua utilização exclusiva na sentença condenatória é também vislumbrada por ANDREY BORGES DE MENDONÇA ${ }^{171}$. Segundo o autor, diferente da solução sobre as provas cautelares e antecipadas, as provas não repetíveis não poderão isoladamente servir na decisão condenatória, visto que são provas colhidas no inquérito e o contraditório não foi e não poderá ser observado em nenhum momento.

Portanto, assim como os dados do inquérito do caput do art. 155 as provas não repetíveis deverão ser corroboradas pelas provas produzidas em juízo:

"Para esta, como não há contraditório, seja anterior ou posterior, impossível ao magistrado se fundar exclusivamente nela para condenar. $\mathrm{O}$ magistrado apenas poderá considerá-la como elemento de reforço das provas coletadas em juízo, conforme dissemos em relação aos demais elementos de informação do inquérito policial $^{172,}$.

Art. 156. A prova da alegação incumbirá a quem a fizer, sendo, porém, facultado ao juiz de ofício:

${ }^{171}$ MENDONÇA, Andrey Borges de. Op. cit., 160-161 p.

${ }^{172}$ MENDONÇA, Andrey Borges de. Op. cit., 161 p. 
I - ordenar, mesmo antes de iniciada a ação penal, a produção antecipada de provas consideradas urgentes e relevantes, observando a necessidade, adequação e proporcionalidade da medida;

II - determinar, no curso da instrução, ou antes de proferir sentença, a realização de diligências para dirimir dúvida sobre ponto relevante.

\subsubsection{Os poderes instrutórios do juiz}

É possível verificar que o legislador da Lei n. 11.690/08 ao acrescentar os incisos atribui mais uma condição de poder instrutório ao juiz. Além de poder "determinar, no curso da instrução, ou antes de proferir sentença, a realização de diligências para dirimir dúvida sobre ponto relevante", o legislador adicionou uma nova forma de intervenção judicial quando é facultado ao juiz de ofício "ordenar, mesmo antes de iniciada a ação penal, a produção antecipada de provas consideradas urgentes e relevantes, observando a necessidade, adequação e proporcionalidade da medida".

A imparcialidade é bastante questionada nessas situações quando se fala em sistema acusatório e a necessidade de uma posição equidistante do juiz na causa. Porém, esses poderes concedidos ao juiz desde que fixados limites ${ }^{173}$ fazem parte da nova realidade de um Estado Democrático de Direito, como defende ADA PELLEGRINI GRINOVER ${ }^{174}$ :

"Trata-se da função social do processo, que depende de sua efetividade. Nesse quadro, não é possível imaginar um juiz inerte, passivo, refém das partes. Não pode ele ser visto como mero espectador de um duelo judicial de interesse exclusivo dos contendores. Se o objetivo da atividade jurisdicional é a manutenção da integridade do ordenamento jurídico, para o atingimento da paz social, o juiz deve desenvolver todos os esforços para alcançá-lo. Somente assim a jurisdição atingirá seu escopo social”.

\footnotetext{
${ }^{173}$ GOMES FILHO, Antônio Magalhães (1). Op. cit., 259 p. O autor também admite que poderes instrutórios sejam concedidos ao juiz no sistema acusatório, desde que existam limites, como por exemplo, a necessidade de motivação das decisões e que a observação do contraditório, mesmo quando determina alguma diligência de ofício antes de instaurada a ação penal.

${ }_{174}$ GRINOVER, Ada Pellegrini. A iniciativa instrutória do juiz no processo acusatório. In: A marcha do processo. Rio de Janeiro: Forense Universitária, 2000. 80 p.
} 
Desse modo, o inciso I do artigo 156 deve ter uma interpretação feita conforme a Constituição para que a imagem de um juiz investigador seja posta de lado. Com isso, o objetivo do inciso é impedir que uma possível prova pereça no tempo, permitindo ao juiz que instaure o incidente de antecipação probatória ${ }^{175}$.

LUIZ FLÁVIO GOMES ${ }^{176}$ (ET. AL.) confirma esta nova posição alcançada pelo juiz que não deve se contentar com o que lhe é apresentado pelas partes e assim, procurar completá-las para alcançar a melhor decisão jurisdicional. O autor também critica a nova redação do art. 156, inciso I, pois este desrespeita o sistema acusatório:

“(...) a um só tempo o juiz se transforma em delegado de polícia e promotor de justiça, quando ordena a produção de uma prova ao primeiro, antes mesmo de deflagrada a ação penal, a cargo do Ministério Público, o segundo. Ora, a incumbência de requisitar a produção de prova, na fase do inquérito policial, deve ser deferida, somente ao promotor de justiça (...). São atividades que não podem ficar na mão de uma mesma pessoa, sob pena de comprometer a eficácia das garantias individuais do sujeito passivo e própria credibilidade da administração da justiça (...)".

Art. 159. O exame de corpo de delito e outras perícias serão realizados por perito oficial, portador de diploma de curso superior.

$\$ 1^{\circ}$. Na falta de perito oficial, o exame será realizado por 2 (duas) pessoas idôneas, portadoras de diploma de curso superior preferencialmente na área específica, dentre as que tiverem habilitação técnica relacionada com a natureza do exame.

$\$ 2^{\circ}$. Os peritos não oficiais prestarão o compromisso de bem e fielmente desempenhar o encargo.

$\$^{\mathbf{0}}$. Serão facultadas ao Ministério Público, ao assistente de acusação, ao ofendido, ao querelante e ao acusado a formulação de quesitos e indicação de assistente técnico.

$\$ 4^{\circ}$. O assistente técnico atuará a partir de sua admissão pelo juiz e após a conclusão dos exames e elaboração do laudo pelos peritos oficiais, sendo as partes intimadas desta decisão.

\footnotetext{
${ }^{175}$ GOMES FILHO, Antônio Magalhães (1). Op. cit., 260-261 p.

${ }^{176}$ GOMES, Luiz Flávio. Op. cit., 278-280 p.
} 
$\$ 5^{\circ}$. Durante o curso do processo judicial, é permitido às partes, quanto à perícia:

I - requerer a oitiva dos peritos para esclarecerem a prova ou para responderem a quesitos, desde que o mandado de intimação e os quesitos ou questões a serem esclarecidas sejam encaminhados com antecedência mínima de 10 (dez) dias, podendo apresentar as respostas em laudo complementar;

II - indicar assistentes técnicos que poderão apresentar pareceres em prazo a ser fixado pelo juiz ou ser inquiridos em audiência.

$\$ \mathbf{6}^{\mathbf{0}}$. Havendo requerimento das partes, o material probatório que serviu de base à perícia será disponibilizado no ambiente do órgão oficial, que manterá sempre sua guarda, e na presença d perito oficial, para exame pelos assistentes, salvo se for impossível a sua conservação.

$\$ 7^{\circ}$. Tratando-se de perícia complexa que abranja mais de uma área de conhecimento especializado, poder-se-á designar a atuação de mais de um perito oficial, e a parte indicar mais de um assistente técnico.

\subsubsection{A prova pericial e o contraditório}

As provas periciais tem grande relevância no processo penal devido às suas informações científicas e técnicas, mas isso não significa que as partes e o juiz sejam passivos aos seus dados e que esse saber peculiar nunca falhe.

Dessa forma, o legislador da Lei n. 11.690/08 preocupado com a disciplina da perícia, normalmente realizada na fase investigativa, introduziu amparos à participação das partes em contraditório na busca pela verdade processual $^{177}$ e procurou tornar mais fácil a realização das perícias $^{178}$.

Para tanto, a nova redação do art. 159, preocupada em estimular a participação das partes em contraditório, introduziu a inusitada figura do

\footnotetext{
${ }^{177}$ GOMES FILHO, Antônio Magalhães (1). Op. cit., 273-275 p.

${ }^{178}$ MENDONÇA, Andrey Borges de. Op. cit., 182 p.
} 
assistente técnico, alterou o número de peritos e possibilitou a articulação de quesitos pelas partes e solicitação de esclarecimentos aos peritos oficiais.

Quanto aos quesitos, estes poderão ser formulados pelas partes e esclarecidos pelos peritos $\left(\$ 5^{\circ}\right.$, art. 159$)$ como exemplo ao estímulo à participação em contraditório da partes na prova pericial ${ }^{179}$.

\subsubsection{A alteração quanto ao número de peritos e a figura do assistente técnico}

Os peritos oficiais como o próprio nome diz estão vinculados ao juízo e, por isso, submetidos às devidas normas processuais ${ }^{180}$. A Código de Processo Penal de 1941 exigia dois peritos oficiais na tentativa de atingir certa segurança nos dados, mas com a Lei n. 11.690 passou-se a exigir apenas um perito oficial, salvo se a perícia for complexa e necessite mais de um especialista de outra área $\left(\$ 7^{\circ}\right.$, art. 159).

A atuação de apenas um perito oficial é corroborada com a possibilidade de ser nomeado o assistente técnico pelas partes ou outros peritos pelo juiz e ser feita a formulação de quesitos $\left(\$ \S 3^{\circ}\right.$ e $5^{\circ}$, do art. 159 , respectivamente). Nesse ponto, a figura do assistente técnico enseja novos alcances ao princípio do contraditório e da ampla defesa já que há a possibilidade de indicação desses assistentes pelo Ministério Público, acusado, ofendido, assistente de acusação e pelo querelante ${ }^{181}$.

LUIZ FLÁVIO GOMES critica a atuação do assistente apenas na fase processual e defende a introdução dos princípios do contraditório e da ampla defesa já na investigação, o que é inconcebível porque, como questão

\footnotetext{
${ }^{179}$ GOMES FILHO, Antônio Magalhães (1). Op. cit. 276-277 p.

${ }^{180} \mathrm{O}$ código também estende à figura dos peritos não oficiais, o que não ocorre com os assistentes técnicos. Art. 275 do CPP: "O perito, ainda que não oficial, estará sujeito à disciplina judiciária". Art. 279 do CPP: "Não poderão ser peritos: I - os que estiverem sujeitos à interdição de direito mencionada nos ns. I e IV do art. 69 do Código Penal; II - os que tiverem prestado depoimento no processo ou opinado anteriormente sobre o objeto da perícia; III - os analfabetos e os menores de 21 (vinte e um) anos". Art. 280 do CPP: "É extensivo aos peritos, no que lhes for aplicável, o disposto sobre suspeição dos juízes”.

${ }^{181}$ MENDONÇA, Andrey Borges de. Op. cit. 185-186 p.
} 
amplamente discutida, essas garantias não podem ser aplicadas nesta fase devido à natureza do inquérito policial ${ }^{182}$.

\section{Conforme diz ANDREY BORGES DE MENDONÇA ${ }^{183}$ deveria} ser aceito a participação dos assistentes durante a produção da prova para "melhor assegurar o contraditório", mesmo que em momento posterior.

Apesar das restrições, a introdução da figura do assistente técnico permite uma maior garantia ao princípio do contraditório e da ampla defesa, permitindo que o magistrado tenha a oportunidade de avaliar outros laudos que não seja somente o oficial ${ }^{184}$.

\subsection{Críticas à Reforma}

A reforma do Código de Processo Penal que deu origem às Leis $11.689 / 08,11.690 / 08$ e 11.719/08 sofreu duras críticas por diversos doutrinadores e juristas justamente por não ser uma reforma integral, e sim, pontual.

AURY LOPES JUNIOR $^{185}$ afirma que a falta de um princípio unificador traduz uma reforma insuficiente e repleta de lacunas, mas entende que, no Brasil, o processo legislativo encontra dificuldades às reformas totais visto que a mentalidade, não somente dos legisladores, mas também de grande parcela da comunidade jurídica, precisa romper com uma estrutura cultural que ainda mantém velhos hábitos.

Nesse sentido, sustenta que o art. 155 do Código de Processo Penal, após a reforma, não trouxe mudanças, pois o juiz continua com legitimidade para condenar com base nos elementos informativos colhidos no inquérito

${ }^{182}$ GOMES, Luiz Flávio. Op. cit., 291-293 p. O autor entende também que o legislador deveria ter acompanhado a legislação processual civil que prevê, no seu art. 425, a possibilidade das partes formularem quesitos ainda no decorrer das diligências, mas não o fez, prejudicando o trabalho técnico a ser oferecido.

${ }^{183}$ MENDONÇA, Andrey Borges de. Op. cit., 186 p.

${ }^{184}$ GOMES, Luiz Flávio. Op. cit., 290 p.

${ }^{185}$ LOPES JUNIOR, Aury. Bom pra quê (m)? Bol.IBCCrim 188. Afirma o autor que a reforma trouxe inovações de pequeno relevo e apenas reformou a matriz inquisitória do sistema processual penal brasileiro. Faz referência também ao art. 157 do Código de Processo Penal sobre as provas ilícitas e critica, principalmente, o veto ao $\S 4^{\circ}$ que, finalmente, traria alguma inovação substancial: "o juiz que conhecer do conteúdo da prova declarada inadmissível não poderá proferir a sentença ou o acórdão". 
policial. À medida que lhe é facultado sentenciar com base nesses elementos, a reforma nada muda de efetivo e continua a negar a plenitude do princípio do contraditório.

Para tanto, consolida que uma verdadeira reforma seria aquela que romperia de vez com o sistema inquisitório e, para isso, seria extremamente necessário separar fisicamente os autos do inquérito policial da ação penal.

Ainda assim, critica fortemente o art. 156 que atribuiu poderes de ofício ao juiz o qual deveria manter uma posição afastada da produção das provas e atuar como um juiz garantidor dos direitos e garantias fundamentais em uma estrutura dialética de processo.

\section{Ainda nesse sentido, JACINTO NELSON DE MIRANDA} COUTINHO $^{186}$ acompanha a mesma opinião e confirma que a reforma do Código é parcial e incongruente, pois não houve mudança alguma de fato. Considera ainda que o discurso sobre celeridade ${ }^{187}$ utilizado nas exposições de motivo do anteprojeto é extremamente perigoso, já que a fundamental preocupação do processo penal é realizar o devido processo com base na observação dos direitos e garantias fundamentais e a busca pela celeridade poderia comprometê-los.

A incompatibilidade entre a Constituição Federal e o sistema inquisitorialista ${ }^{188}$ do Código de Processo Penal exige também um princípio

\footnotetext{
${ }^{186}$ COUTINHO, Jacinto Nelson de Miranda. As Reformas parciais do CPP e a gestão da prova: segue o princípio inquisitivo. Bol. Ibccrim 188

${ }^{187}$ No sentido contrário, declara Pedro Abramoyal que "Um processo penal mais célere, presente em todos os projetos debatidos, é requisito fundamental para a efetividade do sistema penal e para a redução da sensação de impunidade no Brasil." MOURA, Maria Thereza Rocha de Assis et al.. As Reformas no processo penal: as novas leis de 2008 e os projetos de reforma. São Paulo: Revista dos Tribunais, 2009. 9p.

188 Para Jacinto Coutinho o sistema processual do Código de Processo Penal continua inquisitorialista como se vê na seguinte passagem: "Ora, se o processo tem por finalidade, entre outras - mas principalmente - o acertamento de um caso penal após a reconstituição de um fato pretérito, o crime, mormente através da instrução probatória, é a gestão da prova e a forma pela qual ela é realizada que identifica o princípio unificador". Portanto, a concentração do poder de produção probatória nas mãos do juiz nega qualquer efetiva aplicação do princípio do contraditório, diferentemente do que ocorre no sistema acusatório em que o juiz é garante dos direitos e garantias constitucionais. A solução encontrada pelo autor consiste no fim do inquérito policial e a adoção de uma única instrução, ou seja, uma reforma integral no sistema. COUTINHO, Jacinto Nelson de Miranda. As Reformas parciais do CPP e a gestão da prova: segue o princípio inquisitivo. Bol. Ibccrim 188.
} 
unificador capaz de mudar o sistema processual vigente, sendo que essa mudança somente será possível com uma reforma integral do Código.

\subsection{O PLS no. 156/2009 do novo Código de Processo Penal}

Nova comissão de juristas ${ }^{189}$ foi formada para a elaboração de um anteprojeto de reforma do Código de Processo Penal, sendo o coordenador do anteprojeto o Ministro Hamilton Carvalhido e o relator, o Dr. Eugênio Pacelli de Oliveira.

Na introdução da exposição de motivos do projeto de lei do Senado é demonstrada a preocupação da comissão na dissonância entre as normas vigentes do Código de Processo Penal e os princípios postulados na Constituição da República de 2008, fazendo-se necessário a elaboração de um novo Código para superar o antigo. Segundo o coordenador

\section{HAMILTON CARVALHIDO:}

"A incompatibilidade entre os modelos normativos do citado Decreto-lei $\mathrm{n}^{\mathrm{o}}$ 3.689, de 1941 e da Constituição de 1988 é manifesta e inquestionável. E essencial. A configuração política do Brasil de 1940 apontava em direção totalmente oposta ao cenário das liberdades públicas abrigadas no atual texto constitucional".

\subsubsection{0 juiz de garantias}

O objetivo do PLS no 156/2009 é garantir que o juiz se mantenha imparcial e afastado de qualquer atividade instrutória na investigação (art. $4^{\mathrm{o}}$ do anteprojeto $2009^{190}$ ), somente sendo permitida a sua presença nesta primeira fase para tutelar as liberdades individuais. A escolha não é por juiz

\footnotetext{
189 A comissão é formada pelos seguintes juristas: Ministro Hamilton Carvalhido (coordenador), Eugênio Pacelli de Oliveira (relator), Antonio Correa, Antonio Magalhães Gomes Filho, Fabiano Augusto Martins Silveira, Felix Valois, Coelho Júnior, Jacinto Nelson de Miranda Coutinho, Sandro Torres de Avelar e Tito Souza do Amaral.

${ }^{190}$ Art. $4^{\circ}$. O processo penal terá estrutura acusatória, nos limites definidos neste Código, vedada a iniciativa do juiz na fase de investigação e a substituição da atuação probatória do órgão de acusação.
} 
inerte, e sim por um juiz ativo na tutela dos direitos e garantias individuais e em busca da melhor prestação jurisdicional ${ }^{191}$.

Nesse sentido, a inovação é a previsão de um juiz de garantias (art. 15 , caput, do anteprojeto $^{192}$ ), responsável pelo exercício jurisdicional de preservação dos direitos e garantias individuais, que estará direcionado a esta função exclusiva e não será confundido com o juiz do processo (art. 17 do anteprojeto ${ }^{193}$ ).

Dessa forma, o objetivo da previsão de um juiz de garantias e de outro para o processo é evitar que o mesmo juiz que tomou conhecimento dos dados colhidos no inquérito policial sentencie a causa. A intenção é preservar a imparcialidade dos juízes e impedir que esta seja prejudicada.

\subsubsection{Os elementos de informação do Inquérito Policial}

A investigação criminal continua a preservar suas peculiaridades, entre elas, o não acesso do advogado e do investigado às diligências em andamento, mas o anteprojeto prevê expressamente o seu poder de acesso a todo o material produzido na investigação (art. 12 do $\operatorname{PLS}^{194}$ ), questão bastante discutida na jurisprudência há algum tempo.

$\mathrm{O}$ projeto de lei define estritamente a função dos elementos informativos colhidos no inquérito policial, as quais são apenas duas: estão destinados à formação do convencimento da opinio delicit do Ministério

\footnotetext{
${ }^{191}$ Segundo a Exposição de Motivos (II): "Não se optou pelo juiz inerte, de resto inexistente nos países de maior afinidade processual com o Brasil, casos específicos de Portugal, Itália, Espanha e Alemanha, e que também adotam modelos acusatórios, mas, sim, pelo fortalecimento das funções de investigação e, assim, das respectivas autoridades, e pela atribuição de responsabilidade processual ao Ministério Público. O que não significará, um mínimo que seja, o alheamento judicial dos interesses da aplicação da lei penal. Instaurado o processo, provocada a jurisdição, poderá o juiz, de ofício, adotar até mesmo medidas acautelatórias, quando destinadas a tutelar o regular exercício da função jurisdicional”.

${ }^{192}$ Art. 15, caput. O juiz das garantias é responsável pelo controle da legalidade da investigação criminal e pela salvaguarda dos direitos individuais cuja franquia tenha sido reservada à autorização prévia do Poder Judiciário, competindo-lhe especialmente.

${ }^{193}$ Art. 17. O juiz que, na fase de investigação, praticar qualquer ato incluído nas competências do art. 15 ficará impedido de funcionar no processo.

${ }^{194}$ Art. 12. É garantido ao investigado e ao seu defensor acesso a todo material já produzido na investigação criminal, salvo no que concerne, estritamente, às diligências em andamento. Parágrafo único. O acesso compreende consulta ampla, apontamentos e reprodução por fotocópia ou outros meios técnicos compatíveis com a natureza do material.
} 
Público sobre a realização da acusação e à efetivação das medidas acautelatórias (art. 33 do $\operatorname{PLS}^{195}$ ). A delimitação do inquérito é bem definida pelo PLS de 2009, explicitando ainda que o procedimento administrativo esteja limitado à preparação da denúncia pelo Ministério Público (art. 36 do PLS ${ }^{196}$ ).

Dessa forma, ao contrário do que está previsto no art. 155 do Código de Processo Penal, modificado com a Lei 11.690/08, o juiz deverá formar seu livre convencimento com base na prova produzida em contraditório (art. 165, caput, do $\mathrm{PLS}^{197}$ ), não deixando margem à possibilidade de utilização de elementos de informação.

Porém, o $\S 1^{\circ}$ do art. 165 abre uma oportunidade de interpretação quanto à utilização desses elementos quando diz que "a existência de um fato não pode ser inferida de indícios, salvo quando forem graves, precisos e concordantes", o que parece um pouco preocupante já que esta dedução dependerá da discricionariedade do magistrado.

\subsubsection{A prova pericial}

Quanto às provas periciais não há muitas inovações, pois a participação das partes em contraditório continua sendo realizada no processo e não será atribuída à fase de investigação (art. 197 do PLS ${ }^{198}$ )

A previsão de indicação de assistente técnico pelas partes ainda continua, assim como a apresentação de quesitos para esclarecimentos

\footnotetext{
195 Art. 33. Os elementos informativos da investigação deverão ser colhidos na medida necessária à formação do convencimento do Ministério Público sobre a viabilidade da acusação, bem como à efetivação de medidas cautelares, pessoais ou reais, a serem decretadas pelo juiz das garantias. ${ }^{196}$ Art. 36. Os autos do inquérito instruirão a denúncia, sempre que lhe servir de base.

${ }^{197}$ Art. 165, caput. O juiz formará livremente o seu convencimento com base nas provas submetidas ao contraditório judicial, indicando na fundamentação os elementos utilizados e os critérios adotados.

198 Art. 197. Durante o curso do processo judicial, é permitido às partes, quanto à perícia: I requerer a inquirição dos peritos para esclarecerem a prova ou para responderem a quesitos, desde que o mandado de intimação e os quesitos ou questões a serem esclarecidas sejam encaminhados com antecedência mínima de 10 (dez) dias, podendo apresentar as respostas em laudo complementar; II - indicar assistentes técnicos que poderão apresentar pareceres em prazo a ser fixado pelo juiz ou ser inquiridos em audiência.
} 
sobre as provas técnicas (art. 196, $\$ 4^{\text {o }}$ do $\mathrm{PLS}^{199}$ ). Portanto, o contraditório continua sendo exercido de forma efetiva, mas no processo judicial.

\subsection{A melhor opção de Código de Processo Penal}

É inegável que o Código de Processo Penal de 1941, no tema das provas, com a reforma pela Lei 11.690/08 trouxe modificações expressivas no cenário do processo penal brasileiro, apesar de não ter sido uma modificação integral e harmônica como muitos juristas sustentam.

A delimitação do livre convencimento do juiz às provas submetidas ao contraditório e a introdução expressa do princípio do contraditório na realização das provas periciais são bons exemplos de modificações pontuais que levam a crer que a busca pela implementação dos postulados da Constituição Federal de 1988 é o objetivo.

Porém, ainda há muitas modificações a serem realizadas, pois muitas disparidades entre a legislação ordinária e o sistema de processo adotado pela CR/88 ainda perduram, como por exemplo:

1. A possibilidade de o juiz fundamentar a decisão em elementos de informação colhidos no inquérito policial, mesmo que corroborados com as provas em contraditório (art. 155, do CPP);

2. A previsão de alguns poderes instrutórios do juiz na fase de investigação, como a instauração de inquérito policial pela requisição do magistrado (art. $5^{\circ}$, II, do CPP) e a possibilidade de ordenar de ofício, mesma na fase de investigação, a produção antecipada de provas;

3. O juiz que concede as medidas cautelares ser o mesmo competente para julgar o mérito da causa; e

4. O fato de o inquérito policial continuar a acompanhar a acusação do Ministério Público na Ação Penal.

199 Art. 196, § 4 . Serão facultadas ao Ministério Público, ao assistente de acusação, à vítima, ao querelante, ao indiciado e ao acusado a formulação de quesitos. 
Importantes e expressivas modificações foram, também, realizadas no PLS nº 156/2009 da comissão do Ministro HAMILTON CARVALHIDO, como a delimitação expressa da função dos elementos de informação e a previsão de um juiz de garantias diverso do juiz que julgará a causa, como discutido no item pertinente.

Apesar disso, alguns pontos relevantes ainda não foram modificados, o que leva a crer que a melhor opção a ser adotada é o Código Modelo de Processo Penal para Ibero - América o qual foi utilizado como parâmetro pela comissão presidida pela jurista ADA PELLEGRINI GRINOVER na proposta de seu anteprojeto.

Embora tenha sido parâmetro para a reforma do Código de Processo Penal de 2008, muitos de seus institutos não foram recepcionados por alguns setores jurídicos da sociedade e suprimidos pelo Congresso Nacional, o que fazem total diferença na escolha do melhor instituto.

O Código Modelo deixa clara a ausência de valor probatório dos elementos de informação colhidos no inquérito policial e delimita sua função, exclusiva, para a formação da opinio delict do Ministério Público, ressalvada a sua utilização no incidente de antecipação de provas, realizado sob o crivo do contraditório.

Além disso, prevê o desentranhamento do inquérito policial dos autos da ação penal condenatória, evitando qualquer tipo de contaminação, mesmo que inconsciente, da imparcialidade do juiz, fazendo com que sua fundamentação esteja estritamente vinculada aos atos de prova produzidos à luz do contraditório.

E, por fim, a existência de um juiz de garantias que analisa as medidas cautelares e a admissibilidade da acusação, diverso do juiz do processo, evitando, mais uma vez, qualquer comprometimento da imparcialidade do magistrado e a manipulação do mesmo com relação aos dados colhidos no procedimento administrativo.

Por isso, comparando as previsões pertinentes, a melhor disciplina jurídica sobre a valorização judicial dos elementos de informação da 
investigação criminal, à luz do sistema acusatório é o Código Modelo de Processo Penal para Ibero - América. 


\section{Conclusão}

I. O estudo do histórico dos sistemas processuais penais demonstra que a origem do sistema processual de cunho acusatório é o processo penal romano. Seu sistema acusatório delimitava bem as funções de acusar, defender e julgar, pela preponderância do princípio acusatório na estrutura dialética das partes e a situação do investigado e do acusado como sujeito de direitos.

II. O sistema acusatório compreende o conjunto de normas e princípios do devido processo legal orientado por um princípio superior, o princípio acusatório, orientador de uma gama de princípios definidores do sistema em questão.

III. Na conceituação de um sistema processual propriamente dito, as características mais evidentes são: divisão de funções (acusar, defender e julgar), o acusado como sujeito de direitos fundamentais e a oralidade e publicidade dos atos processuais.

IV. A partir da análise das características gerais do sistema acusatório, é possível verificar qual o sistema processual eleito pela Constituição Federal de 1988: o sistema acusatório. Este sistema é inerente ao Estado Democrático de Direito o qual foi acolhido pela Lei Maior.

V. Muitas controvérsias surgem quanto à eleição do sistema acusatório pela Constituição Federal. Há quem o considere inquisitivo, misto e acusatório, mas não há dúvida que a Constituição, através de seus expressos princípios, escolheu o sistema acusatório.

VI. O investigado também é sujeito de direitos fundamentais e isso decorre do princípio supremo da dignidade da pessoa humana (art. $1^{\circ}$, III, da CR/88) postulado na Constituição Federal. Dessa forma, é necessário a introdução de certas garantias 
constitucionais na fase de investigação, mas, sobretudo, adequálas à natureza jurídica do procedimento administrativo que é instaurado para verificar a ocorrência de infração penal, o inquérito policial.

VII. O princípio do contraditório é a condição de validade da prova penal, tendo como fundamento político a tese LUHMANN sobre legitimação pelo procedimento. Essa tese relaciona o exercício do poder do Estado e sua vinculação à participação dos destinatários desse poder-dever.

VIII. O princípio do contraditório é a necessidade de informação e a posterior e oportunidade de reação para contrariá-los. É expressão fundamental de um devido processo legal e de um processo justo.

IX. A grande parte da doutrina e da jurisprudência entende que não há possibilidade de introdução do princípio do contraditório na fase de investigação preliminar porque não existe processo nesta fase. A Constituição é clara no art. 5, LV quando diz que o contraditório deve ser observado no processo, portanto, devido à sua natureza de procedimento administrativo, o inquérito não comporta o contraditório nem a ampla defesa.

X. Os elementos informativos são assim chamados porque foram colhidos na fase de investigação preliminar e por não comportarem o princípio do contraditório, não tem valor probatório na sentença penal condenatória, ressalvadas as provas cautelares, antecipadas e irrepetíveis que comportam um contraditório diferido.

XI. Os elementos de informação possuem duas funções: estão destinados a formar o convencimento da opinio delicti do Ministério Público e servir de base nas concessões de medidas cautelares. 
XII. A comissão do anteprojeto do Código de Processo Penal, presidida por Ada Pellegrini Grinover, realizou diversos estudos sobre os sistemas processuais penais nos países que adotam o sistema acusatório e se baseou, principalmente, no Código Modelo para Ibero - América.

XIII. O projeto de lei $\mathrm{n}^{\circ} 4.205 / 01$ deu origem à Lei 11.690/08 que modificou alguns dispositivos referentes às provas no processo penal. $\mathrm{O}$ anteprojeto previa: a simplificação das provas periciais, uma efetiva cooperação das partes do processo na produção das provas, um procedimento diferente na colheita da prova testemunhal, a inadmissibilidade das provas obtidas ilicitamente e a cisão física do inquérito policial dos autos do processo judicial após o recebimento da denúncia, mas esta última proposta não vingou.

XIV. Muitas críticas foram feitas contra a reforma do Código de Processo Penal pela Lei 11.690/08. Os juristas a consideram extremamente pontual, afirmando a necessidade de uma reforma integral que elimine os resquícios inquisitorialistas que persistem em nome de um eficiente combate à criminalidade.

XV. Por fim, um novo anteprojeto do Código de Processo Penal foi enviado ao Senado e, hoje, se tornou o PLS N N $^{\circ}$ 156/2009, ora em tramitação no Senado Federal. Esse PLS traz muitas modificações importantes, como por exemplo, a introdução de um juiz de garantias diverso do juiz da causa para analisar as medidas cautelares e a impossibilidade de utilização dos elementos de informação coletados no inquérito policial na fundamentação da sentença, ressalvadas as provas cautelares, antecipadas e irrepetíveis. 


\section{BIBLIOGRAFIA}

ABADE, Denise Neves. Garantias do processo penal acusatório: o novo papel do ministério público no processo penal de partes. Rio de Janeiro: Renovar, 2005. 257 p.

ALMADA, Roberto José Ferreira de. A Garantia processual da publicidade. São Paulo: Editora Revista dos Tribunais, 2006. 160 p.

ALMEIDA, Joaquim Canuto Mendes de. Princípio do Contraditório. In: Princípios Fundamentais do Processo Penal. São Paulo: Revista dos Tribunais, 1973.

ALVES, José Carlos Moreira. Direito Romano. $13^{\mathrm{a}}$ Ed. Rio de Janeiro: Editora Forense, 2003.368 p.

Anteprojeto / Comissão de Juristas responsável pela elaboração de anteprojeto de reforma do Código de Processo Penal. — Brasília: Senado Federal, 2009.133p.

BASTOS, Marcelo Lessa. A investigação nos crimes de ação penal de iniciativa pública: papel do Ministério público; uma abordagem à luz do sistema acusatório e do garantismo. Rio de Janeiro: Lumen Juris, 2004.

CALMON FILHO, Petrônio. A investigação criminal na reforma do código de processo penal: agilidade e transparência, In: Revista Brasileira de Ciências Criminais. São Paulo, n. 34, 63-106, abr./jun. 2001.

CHOUKR, Fauzi Hassan. Garantias constitucionais na investigação criminal. $3^{\mathrm{a}}$ ed. Rio de Janeiro: Lumen Júris, 2006. 231 p.

Código Procesal Penal Modelo para Ibero - América

COUTINHO, Jacinto Nelson de Miranda. As Reformas parciais do CPP e a gestão da prova: segue o princípio inquisitivo. Bol. Ibccrim 188.

COUTINHO, Jacinto Nelson de Miranda. Crítica à teoria geral do direito processual penal. Rio de Janeiro: Renovar, 2001. 282 p.

Jacinto Nelson de Miranda. Introdução aos princípios gerais

do direito processual penal brasileiro. In: Revista de Estudos Criminais. Porto Alegre, n.1, 26-51 p. 2001. 
DINAMARCO, Cândido Rangel. O princípio do contraditório e sua dupla destinação. In: Fundamentos do Processo Civil Moderno. $4^{\mathrm{a}}$ ed. São Paulo: Malheiros, 2001.

FERNANDES, Antônio Scarance. Processo Penal Constitucional. 2a ed. São Paulo. Revista dos Tribunais, 2000.

GIORDANI, Mário Curtis. Direito penal romano. $3^{\mathrm{a}}$ Ed. Rio de Janeiro. Lumen Juris, 1997. 153 p.

GOMES, Luiz Flávio et. al.. Comentários às reformas do Código de Processo Penal e da lei de trânsito. São Paulo: Revista dos Tribunais, 2008.

GOMES FILHO, Antônio Magalhães. Direito à prova no processo penal. São Paulo: Revista dos Tribunais, 1997.

O princípio da presunção de inocência na Constituição de 1988 e na Convenção Americana sobre direitos humanos (Pacto de São José da Costa Rica). In: Revista do Advogado no 42. São Paulo: Associação dos Advogados de São Paulo, 1994.

GRINOVER, Ada Pellegrini. As garantias constitucionais do processo. In: Novas tendências do direito processual: de acordo com a constituição de 1988. $2^{a}$ Ed. Rio de Janeiro: Forense Universitária, 1990. 451 p.

condicio na ótica do processo de estrutura cooperatória. In: Novas tendências do direito processual: de acordo com a Constituição de 1988. $2^{\text {a }}$ ed. Rio de Janeiro: Forense Universitária, 1990.

A iniciativa instrutória do juiz no processo acusatório. In: A marcha do processo. Rio de Janeiro: Forense Universitária, 2000.

Introdução: A reforma do processo penal, In: Revista Brasileira de Ciências Criminais. São Paulo, n. 33, p. 304-312, jan./mar.2001.

O Processo em evolução. $2^{\mathrm{a}}$ ed. Rio de Janeiro: Forense Universitária, 1998.

LOPES JUNIOR, Aury. Introdução crítica ao processo penal (fundamentos da instrumentalidade constitucional). $4^{\mathrm{a}}$ Ed. Rio de Janeiro: Lumen Juris, 2006. 315 p. 
LOPES JUNIOR, Aury. Sistemas de Investigação Preliminar no Processo Penal. $4^{\mathrm{a}}$ ed. Rio de Janeiro: Lúmen Júris, 2006. 404 p.

LOPES JUNIOR, Aury. Bom pra quê (m)? Bol.Ibccrim 188.

MALAN, Diogo Rudge. Palestra sobre Inovações nas provas (Lei 11.690/08), In Seminário “A Reforma do Código de Processo Penal”. Rio de Janeiro. 2008.

MALAN. Diogo Rudge. Seminário de Processo Penal apresentado na USP.

MARQUES, José Frederico. Elementos de direito processual penal. V. 1. $2^{\mathrm{a}}$ ed. Rio de Janeiro: Forense, 1965.

José Frederico. Do Processo Penal Acusatório. In: Estudos de direito processual penal. Rio de Janeiro: Forense. 1960.

MENDONÇA, Andrey Borges de. Nova reforma do Código de Processo Penal: comentada artigo por artigo. São Paulo: Método, 2008.

MORAES, Alexandre de. Direito Constitucional. 17 $7^{\mathrm{a}}$ Ed. São Paulo: Editora Atlas, 2005. 536-538 p.

MOURA, Maria Thereza Rocha de Assis et al.. As Reformas no processo penal: as novas leis de 2008 e os projetos de reforma. São Paulo: Revista dos Tribunais, 2009. $502 \mathrm{p}$.

PASSOS, Edilenice. Código de Processo Penal: notícia histórica sobre as comissões anteriores. Disponível em http://www.senado.gov.br/novocpp/pdf/CPP-noticia-historica.pdf. Brasília. 2008.

PRADO, Geraldo. Sistema acusatório: a conformidade constitucional das leis processuais penais. $4^{\mathrm{a}}$ ed. Rio de Janeiro: Lumen Juris, 2006. 270 p.

SAAD, Marta; MALAN, Diogo Rudge. Origens históricas dos sistemas acusatório e inquisitivo, In: Revista dos Tribunais, São Paulo, Vol. 842, Ano 94. 2005.

TUCCI, Rogério Lauria; TUCCI, José Rogério Cruz e. Devido Processo legal e tutela jurisdicional. São Paulo: Revista dos Tribunais, 1993. 


\section{Anexo}

\section{Tabela comparativa 1}

\begin{tabular}{|c|c|c|c|c|}
\hline $\begin{array}{l}\text { Código de Processo } \\
\text { Penal de } 1941\end{array}$ & $\begin{array}{l}\text { Código Modelo de } \\
\text { Processo Penal para } \\
\text { Ibero-América }\end{array}$ & $\begin{array}{l}\text { PL n⿳4.205/01 } \\
\text { (Comissão } \\
\text { Grinover) }\end{array}$ & Lei 11.690/08 & PLS n⿳ 156/09 (Comissão Carvalhido) \\
\hline $\begin{array}{l}\text { Art. 155. No juízo } \\
\text { penal, somente quanto } \\
\text { ao estado de pessoas, } \\
\text { serão observadas as } \\
\text { restrições à prova } \\
\text { estabelecidas na lei } \\
\text { civil. }\end{array}$ & $\begin{array}{l}\text { 148. Libertad de la } \\
\text { prueba. Salvo } \\
\text { previsión expresa en } \\
\text { contrario de la ley, se } \\
\text { podrá probar todos los } \\
\text { hechos y circunstancias } \\
\text { de interes para la } \\
\text { correcta solución del } \\
\text { caso y por cualquier } \\
\text { medio de prueba } \\
\text { permitido. Regirán, en } \\
\text { especial, las } \\
\text { limitaciones de la ley, } \\
\text { relativas al estado civil } \\
\text { de las personas. } \\
\text { Un medio de prueba, } \\
\text { para ser admitido, debe } \\
\text { referirse, directa o } \\
\text { indirectamente, al } \\
\text { objeto de la } \\
\text { averiguación y ser útil }\end{array}$ & 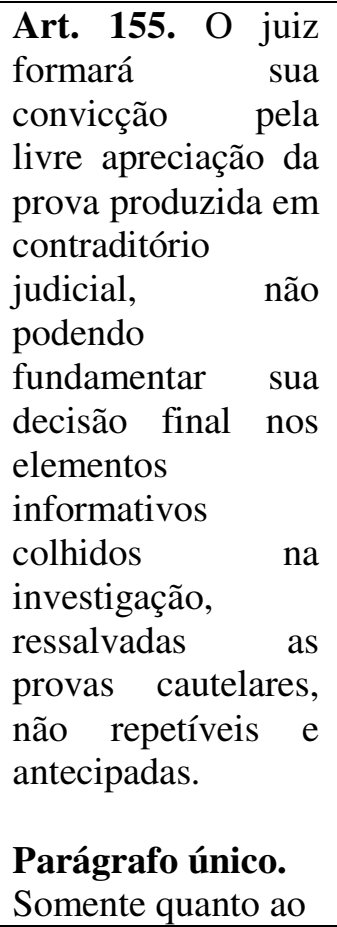 & 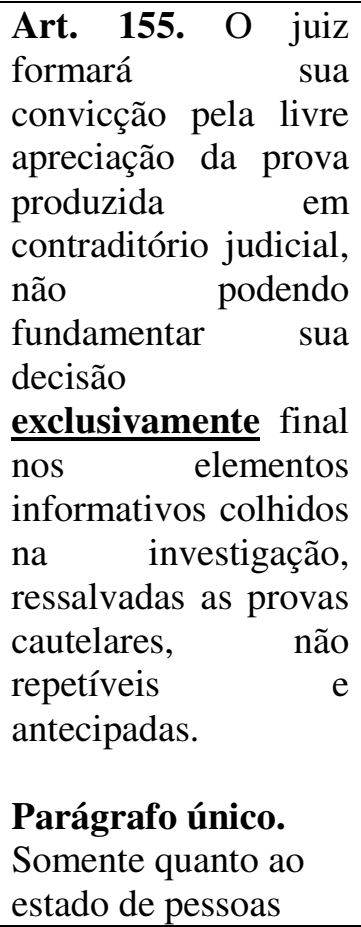 & $\begin{array}{l}\text { Art. 1. O juiz formará livremente o seu } \\
\text { convencimento com base nas provas } \\
\text { submetidas ao contraditório judicial, } \\
\text { indicando na fundamentação os elementos } \\
\text { utilizados e os critérios adotados. } \\
\text { \$1 A existência de um fato não pode ser } \\
\text { inferida de indícios, salvo quando forem } \\
\text { graves, precisos e concordantes. } \\
\$ \mathbf{2}^{\mathbf{0}} \text { As declarações do co-autor ou } \\
\text { partícipe na mesma infração penal só terão } \\
\text { valor se confirmadas por outros } \\
\text { elementos de prova que atestem sua } \\
\text { credibilidade. }\end{array}$ \\
\hline
\end{tabular}




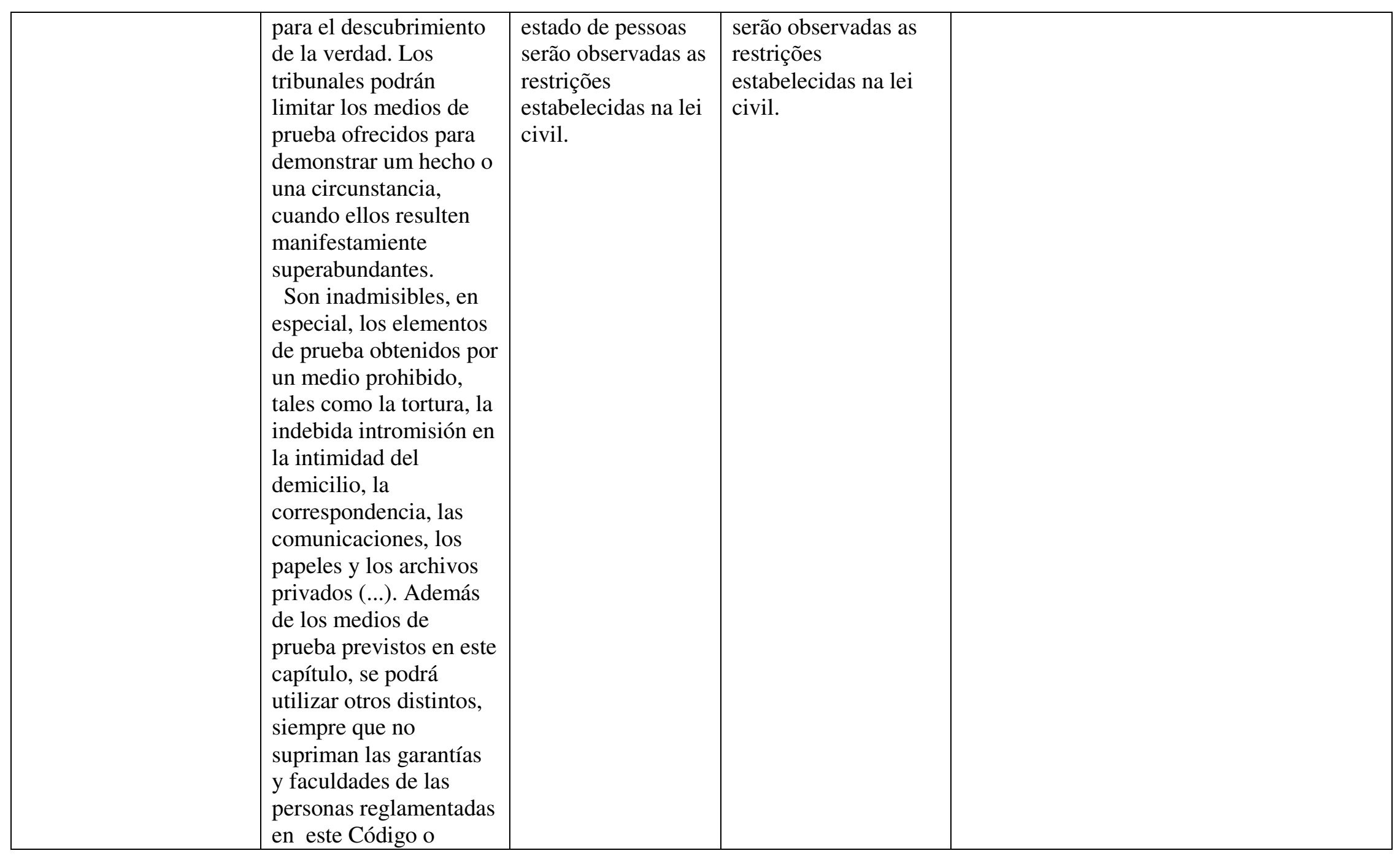




\begin{tabular}{|c|c|c|c|c|}
\hline & $\begin{array}{l}\text { afecten el sistema } \\
\text { institucional. La forma } \\
\text { de su incorporación al } \\
\text { procedimiento se } \\
\text { adecuará al medio de } \\
\text { prueba más análogo, de } \\
\text { los previstos, em lo } \\
\text { posible. }\end{array}$ & & & \\
\hline $\begin{array}{l}\text { Art. 156. A prova da } \\
\text { alegação incumbirá a } \\
\text { quem a fizer; mas o juiz } \\
\text { poderá, no curso da } \\
\text { instrução ou antes de } \\
\text { proferir sentença, } \\
\text { determinar, de ofício, } \\
\text { diligências para dirimir } \\
\text { dúvida sobre ponto } \\
\text { relevante. }\end{array}$ & $\begin{array}{l}\text { Art. 147. OBjetividad, } \\
\text { investigación judicial } \\
\text { autônoma. Salvo que la } \\
\text { ley penal disponga lo } \\
\text { contrario, el miniterio } \\
\text { publico y los tribunales } \\
\text { tienen el deber de } \\
\text { procurar por si la } \\
\text { averiguación de la } \\
\text { verdad mediante los } \\
\text { medios de prueba } \\
\text { permitidos y de cumplir } \\
\text { estrictamente con los } \\
\text { preceptos de los arts. } \\
\text { 232, } 250 \text { y } 272, \text { párr. I. } \\
\text { Durante el juicio, los } \\
\text { tribunales solo podrán } \\
\text { proceder de oficio a la } \\
\text { incorporación de } \\
\text { prueba no oferecida por }\end{array}$ & $\begin{array}{l}\text { Art. 156. A prova } \\
\text { da alegação } \\
\text { incumbirá a quem a } \\
\text { fizer, sendo, porém, } \\
\text { facultado ao juiz: } \\
\text { I - ordenar, mesmo } \\
\text { antes de iniciada a } \\
\text { ação penal, a } \\
\text { produção } \\
\text { antecipada de } \\
\text { provas } \\
\text { consideradas } \\
\text { urgentes e } \\
\text { relevantes, } \\
\text { observando a } \\
\text { necessidade, } \\
\text { adequação e } \\
\text { proporcionalidade } \\
\text { da medida; } \\
\text { II - determinar, de }\end{array}$ & $\begin{array}{l}\text { Art. 156. A prova da } \\
\text { alegação incumbirá a } \\
\text { quem a fizer, sendo, } \\
\text { porém, facultado ao } \\
\text { juiz de ofício: } \\
\text { I - ordenar, mesmo } \\
\text { antes de iniciada a } \\
\text { ação penal, a } \\
\text { produção antecipada } \\
\text { de provas } \\
\text { consideradas urgentes } \\
\text { e relevantes, } \\
\text { observando } \\
\text { necessidade, } \\
\text { adequação } \\
\text { proporcionalidade da } \\
\text { medida; } \\
\text { II - determinar, no } \\
\text { curso da instrução, ou } \\
\text { antes de proferir } \\
\text { sentença, a realização }\end{array}$ & 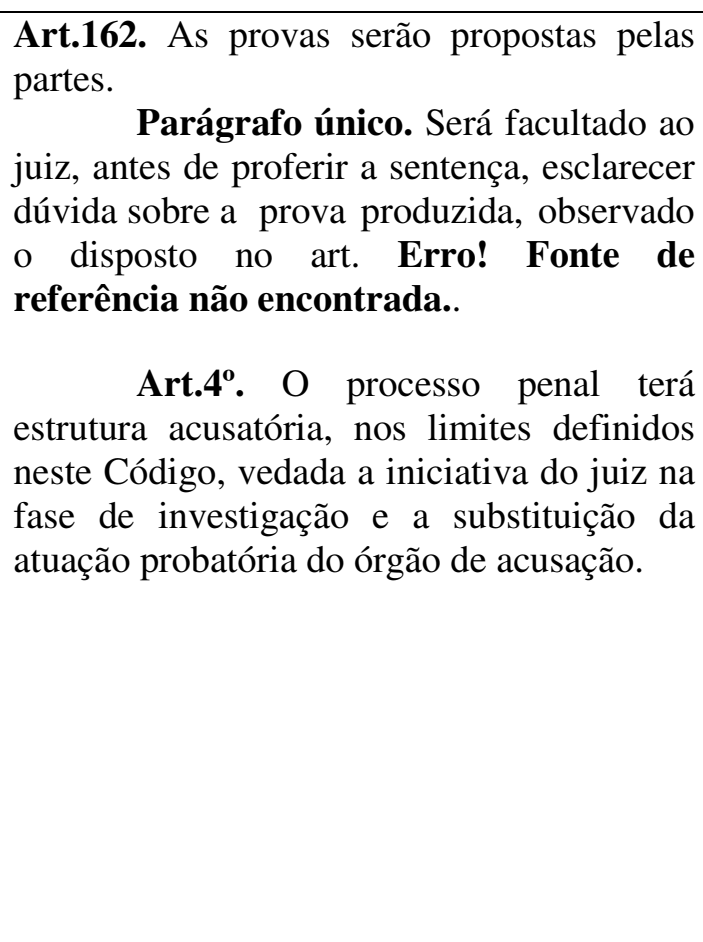 \\
\hline
\end{tabular}




\begin{tabular}{|c|c|c|c|c|}
\hline & $\begin{array}{l}\text { los intervinientes em } \\
\text { las oportunidades y } \\
\text { bajo las condiciones } \\
\text { que fijan los arts. } 285 \text {, } \\
289,316,317 \text { y } 320 .\end{array}$ & $\begin{array}{l}\text { ofício, no curso da } \\
\text { instrução, ou antes } \\
\text { de proferir } \\
\text { sentença, a } \\
\text { realização de } \\
\text { diligências para } \\
\text { dirimir dúvida } \\
\text { sobre ponto } \\
\text { relevante. }\end{array}$ & $\begin{array}{l}\text { de diligências para } \\
\text { dirimir dúvida sobre } \\
\text { ponto relevante. }\end{array}$ & \\
\hline $\begin{array}{l}\text { Art. 159. Os exames de } \\
\text { corpo de delito e as } \\
\text { outras perícias serão } \\
\text { feitos por dois peritos } \\
\text { oficiais. } \\
\text { \$1. Não havendo } \\
\text { peritos oficiais, o } \\
\text { exame será realizado } \\
\text { por duas pessoas } \\
\text { idôneas, portadoras de } \\
\text { diploma de curso } \\
\text { superior, escolhidas, de } \\
\text { preferência, entre as } \\
\text { que tiverem habilitação } \\
\text { técnica relacionada à } \\
\text { natureza do exame. } \\
\text { \$2. Os peritos não } \\
\text { oficiais prestarão o } \\
\text { compromisso de bem e }\end{array}$ & \begin{tabular}{l} 
Art.159. Operaciones \\
técnicas. Para mayor \\
eficacia de los \\
registros, requisas e \\
inspecciones, se podrá \\
ordenar las operaciones \\
técnicas o científicas \\
pertinentes y los \\
reconocimientos y \\
reconstrucciones que \\
correspondieren. \\
\multicolumn{2}{c}{ Si el imputado } \\
decide participar em \\
una reconstrucción, \\
rigem las reglas \\
previstas para su \\
declaración; para \\
testigos, peritos e \\
intérpretes, rigen las \\
previstas em las
\end{tabular} & $\begin{array}{l}\text { Art. 159. O exame } \\
\text { de corpo de delito e } \\
\text { outras perícias } \\
\text { serão, em regra, } \\
\text { realizados por } \\
\text { perito oficial. } \\
\S \text { 1o Na falta de } \\
\text { perito oficial, o } \\
\text { exame será } \\
\text { realizado por duas } \\
\text { pessoas idôneas, } \\
\text { escolhidas, de } \\
\text { preferência, dentre } \\
\text { as que tiverem } \\
\text { habilitação técnica. } \\
\text { 2o Os peritos não } \\
\text { oficiais prestarão o } \\
\text { compromisso de } \\
\text { bem e fielmente }\end{array}$ & $\begin{array}{l}\text { Art. 159. O exame de } \\
\text { corpo de delito e } \\
\text { outras perícias serão } \\
\text { realizados por perito } \\
\text { oficial, portador de } \\
\text { diploma de curso } \\
\text { superior. } \\
\text { \$1.0. Na falta de perito } \\
\text { oficial, o exame será } \\
\text { realizado por 2 (duas) } \\
\text { pessoas idôneas, } \\
\text { portadoras de } \\
\text { diploma de curso } \\
\text { superior } \\
\text { preferencialmente na } \\
\text { área específica, } \\
\text { dentre as que tiverem } \\
\text { habilitação técnica } \\
\text { relacionada com a } \\
\text { natureza do exame. }\end{array}$ & $\begin{array}{l}\text { Art. 196. As perícias serão realizadas por } \\
\text { perito oficial, portador de diploma de curso } \\
\text { superior. } \\
\mathbf{\$ 1}^{\mathbf{0}} \text { Quando o objeto periciado exigir } \\
\text { conhecimentos técnicos específicos, a } \text { perícia poderá ser realizada por servidor } \\
\text { público de carreira, portador de diploma } \\
\text { superior e com comprovada especialização } \\
\text { na matéria. } \\
\mathbf{\$ 2}^{\mathbf{0}} \text { Na falta de perito oficial, o exame será } \\
\text { realizado por } 2 \text { (duas) pessoas idôneas, } \\
\text { portadoras de diploma de curso superior } \\
\text { preferencialmente na área específica, dentre } \\
\text { as que tiverem habilitação técnica } \\
\text { relacionada com a natureza do exame. } \\
\mathbf{3 3}^{\mathbf{0}} \text { Os peritos não oficiais prestarão o } \\
\text { compromisso de bem e fielmente } \\
\text { desempenhar o encargo. } \\
\quad \mathbf{4}^{\mathbf{0}} \text { Serão facultadas ao Ministério } \\
\text { Público, ao assistente de acusação, à vítima, }\end{array}$ \\
\hline
\end{tabular}




\begin{tabular}{|c|c|c|c|c|}
\hline $\begin{array}{l}\text { fielmente desempenhar } \\
\text { o encargo. }\end{array}$ & $\begin{array}{l}\text { secciones } 3^{\mathrm{a}} \text { y } 4^{\mathrm{a}} \text { de este } \\
\text { capítulo. } \\
\text { Art.180. Perito. Serán } \\
\text { ofrecidos o designados } \\
\text { como peritos quienes, } \\
\text { segúnla reglamentación } \\
\text { estatal correspondiente, } \\
\text { acrediten idoneidad en } \\
\text { la materia a que } \\
\text { pertenece el tema sobre } \\
\text { el cual han de } \\
\text { expedirse. Si la ciencia, } \\
\text { arte o técnica no está } \\
\text { reglamentada o si, por } \\
\text { obstáculo insuperable, } \\
\text { no se pudiera contar, en } \\
\text { el lugar del } \\
\text { procedimento, com un } \\
\text { perito habilitado, se } \\
\text { designará a una persona } \\
\text { de idoineidade } \\
\text { manifesta. } \\
\text { No rigen las reglas } \\
\text { de la prueba pericial } \\
\text { para quien declare } \\
\text { sobre hechos o } \\
\text { circunstancias que } \\
\text { conoció } \\
\text { espontáneamente, sin } \\
\text { hacer sido provocado }\end{array}$ & $\begin{array}{l}\text { desempenhar o } \\
\text { encargo. } \\
\text { § 3o Serão } \\
\text { facultadas ao } \\
\text { Ministério Público } \\
\text { e seu assistente, ao } \\
\text { querelante, ao } \\
\text { ofendido, ao } \\
\text { investigado e ao } \\
\text { acusado a } \\
\text { formulação de } \\
\text { quesitos e } \\
\text { indicação de } \\
\text { assistente técnico, } \\
\text { que atuará a partir } \\
\text { de sua admissão } \\
\text { pelo juiz. }\end{array}$ & 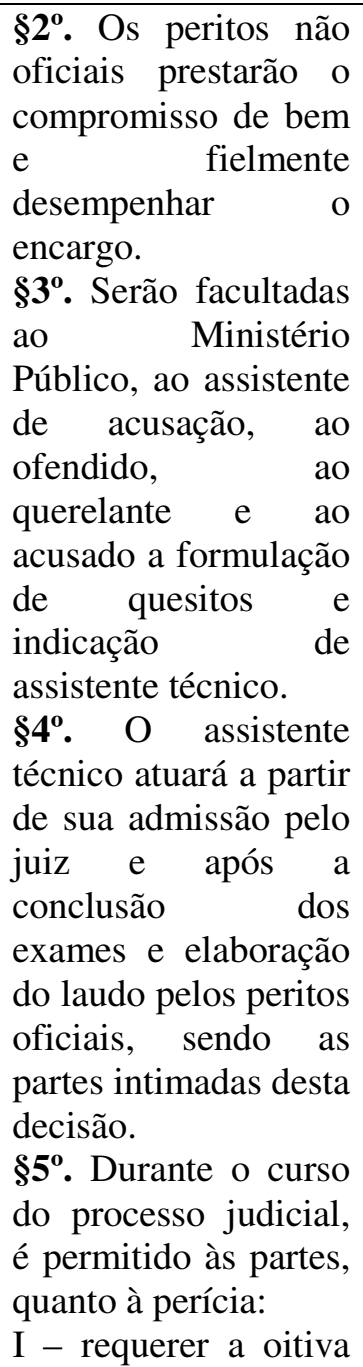 & $\begin{array}{l}\text { Art. 197. Durante o curso do processo } \\
\text { judicial, é permitido às partes, quanto à } \\
\text { perícia: } \\
\text { I - requerer a inquirição dos peritos para } \\
\text { esclarecerem a prova ou para responderem a } \\
\text { quesitos, desde que o mandado de intimação } \\
\text { e os quesitos ou questões a serem } \\
\text { esclarecidas sejam encaminhados com } \\
\text { antecedência mínima de } 10 \text { (dez) dias, } \\
\text { podendo apresentar as respostas em laudo } \\
\text { complementar; } \\
\text { II - indicar assistentes técnicos que poderão } \\
\text { apresentar pareceres em prazo a ser fixado } \\
\text { pelo juiz ou ser inquiridos em audiência. } \\
\text { §1 O assistente técnico atuará a partir de } \\
\text { sua admissão pelo juiz e após a conclusão } \\
\text { dos exames e elaboração do laudo pelos } \\
\text { peritos oficiais, sendo as partes intimadas } \\
\text { desta decisão. } \\
\text { \$2 } \mathbf{2}^{\circ} \text { Havendo requerimento das partes, o } \\
\text { material probatório que serviu de base à } \\
\text { perícia será disponibilizado no ambiente do } \\
\text { órgão oficial e na presença de perito oficial, } \\
\text { que manterá sempre sua guarda, para exame } \\
\text { pelos assistentes, salvo se for impossível a } \\
\text { sua conservação. }\end{array}$ \\
\hline
\end{tabular}




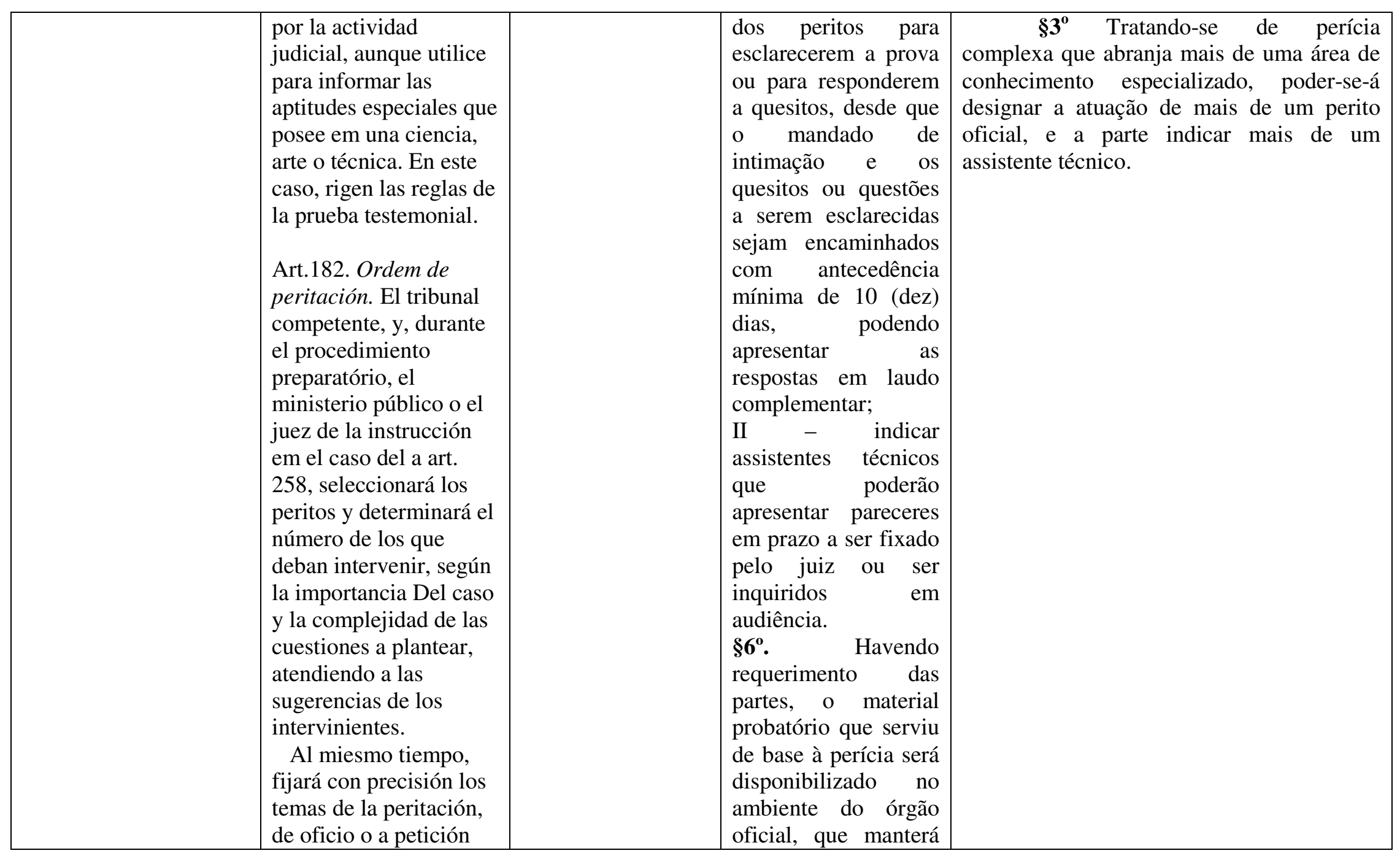




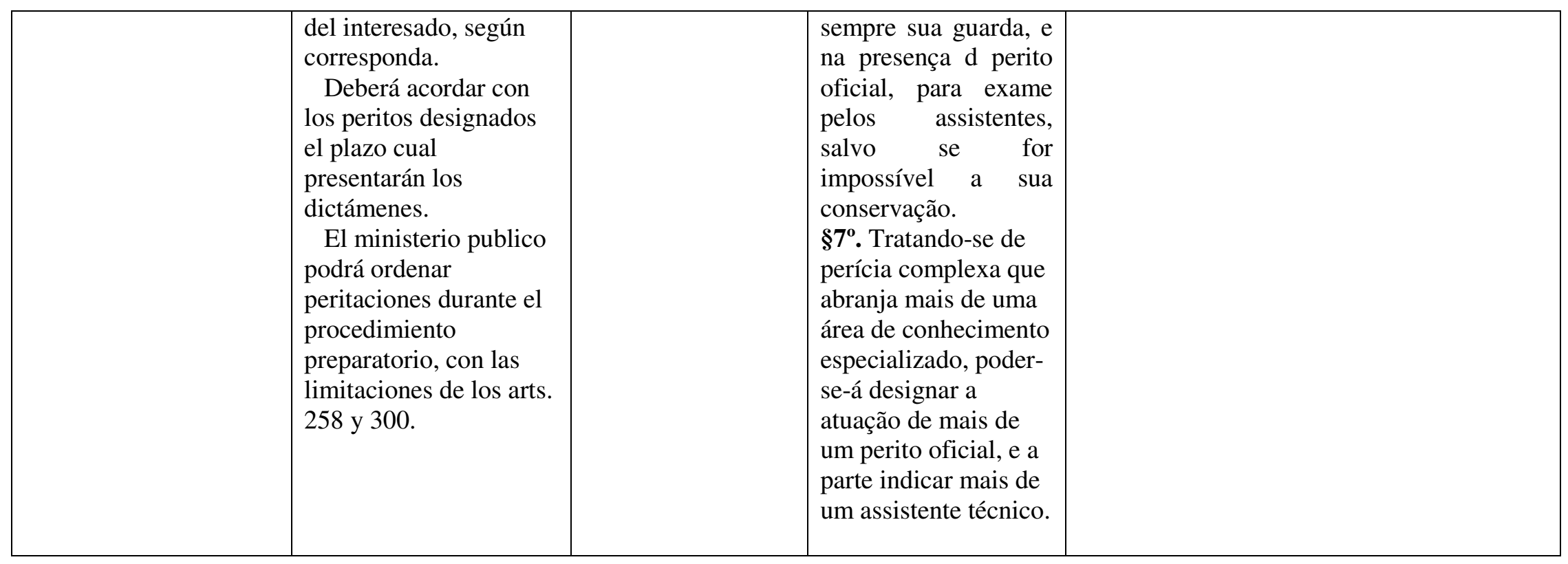


Tabela comparativa 2

\begin{tabular}{|c|c|c|c|c|}
\hline $\begin{array}{l}\text { Código de Processo } \\
\text { Penal de } 1941\end{array}$ & $\begin{array}{l}\text { Código Modelo de } \\
\text { Processo Penal para } \\
\text { Ibero-América }\end{array}$ & $\begin{array}{l}\text { PL no4.209/01 } \\
\text { (Comissão } \\
\text { Grinover) }\end{array}$ & Lei 11.690/08 & PLS n⿳ 156/09 (Comissão Carvalhido) \\
\hline $\begin{array}{l}\text { Art. } \mathbf{7}^{\mathbf{0}} \text {. Para verificar a } \\
\text { possibilidade de haver a } \\
\text { infração penal sido } \\
\text { praticada de } \\
\text { determinado modo, a } \\
\text { autoridade policial } \\
\text { poderá proceder à } \\
\text { reprodução simulado } \\
\text { dos fatos, desde que } \\
\text { esta não contrarie a } \\
\text { moralidade ou a ordem } \\
\text { pública. }\end{array}$ & $\begin{array}{l}\text { 191. Documentos y } \\
\text { elementos de } \\
\text { convicción. Los } \\
\text { documentos, cosas y } \\
\text { otros elementos de } \\
\text { convicción } \\
\text { incorporados al } \\
\text { procedimiento podrán } \\
\text { ser exhibidos al } \\
\text { imputado, a los testigos } \\
\text { y a los peritos, } \\
\text { invitándolos a } \\
\text { reconocer-los y a } \\
\text { informar sobre ellos lo } \\
\text { que fuere pertinente. } \\
\text { Los documentos, cosas } \\
\text { o elementos de } \\
\text { convicción que, según } \\
\text { la ley, deben quedar } \\
\text { secretos o que se } \\
\text { relacionan } \\
\text { directamente con } \\
\text { hechos de la misma } \\
\text { natureleza, serán }\end{array}$ & $\begin{array}{l}\text { Art. 7o Os } \\
\text { elementos } \\
\text { informativos da } \\
\text { investigação } \\
\text { deverão ser colhidos } \\
\text { na medida } \\
\text { estritamente } \\
\text { necessária à } \\
\text { formação do } \\
\text { convencimento do } \\
\text { Ministério Público } \\
\text { ou do querelante } \\
\text { sobre a viabilidade } \\
\text { da acusação, bem } \\
\text { como à efetivação } \\
\text { de medidas } \\
\text { cautelares, pessoais } \\
\text { ou reais, a serem } \\
\text { autorizadas pelo } \\
\text { juiz. } \\
\text { Parágrafo único. } \\
\text { Esses elementos não } \\
\text { poderão constituir } \\
\text { fundamento da }\end{array}$ & $\begin{array}{l}\text { Art. } \mathbf{7}^{\mathbf{0}} \text {. Para } \\
\text { verificar a } \\
\text { possibilidade de } \\
\text { haver a infração } \\
\text { penal sido praticada } \\
\text { de determinado } \\
\text { modo, a autoridade } \\
\text { policial poderá } \\
\text { proceder à } \\
\text { reprodução } \\
\text { simulado dos fatos, } \\
\text { desde que esta não } \\
\text { contrarie a } \\
\text { moralidade ou a } \\
\text { ordem pública. }\end{array}$ & $\begin{array}{l}\text { Art. 33. Os elementos informativos } \\
\text { da investigação deverão ser colhidos na } \\
\text { medida necessária à formação do } \\
\text { convencimento do Ministério Público sobre } \\
\text { a viabilidade da acusação, bem como à } \\
\text { efetivação de medidas cautelares, pessoais } \\
\text { ou reais, a serem decretadas pelo juiz das } \\
\text { garantias. } \\
\text { Art. 36. Os autos do inquérito instruirão a } \\
\text { denúncia, sempre que lhe servir de base }\end{array}$ \\
\hline
\end{tabular}




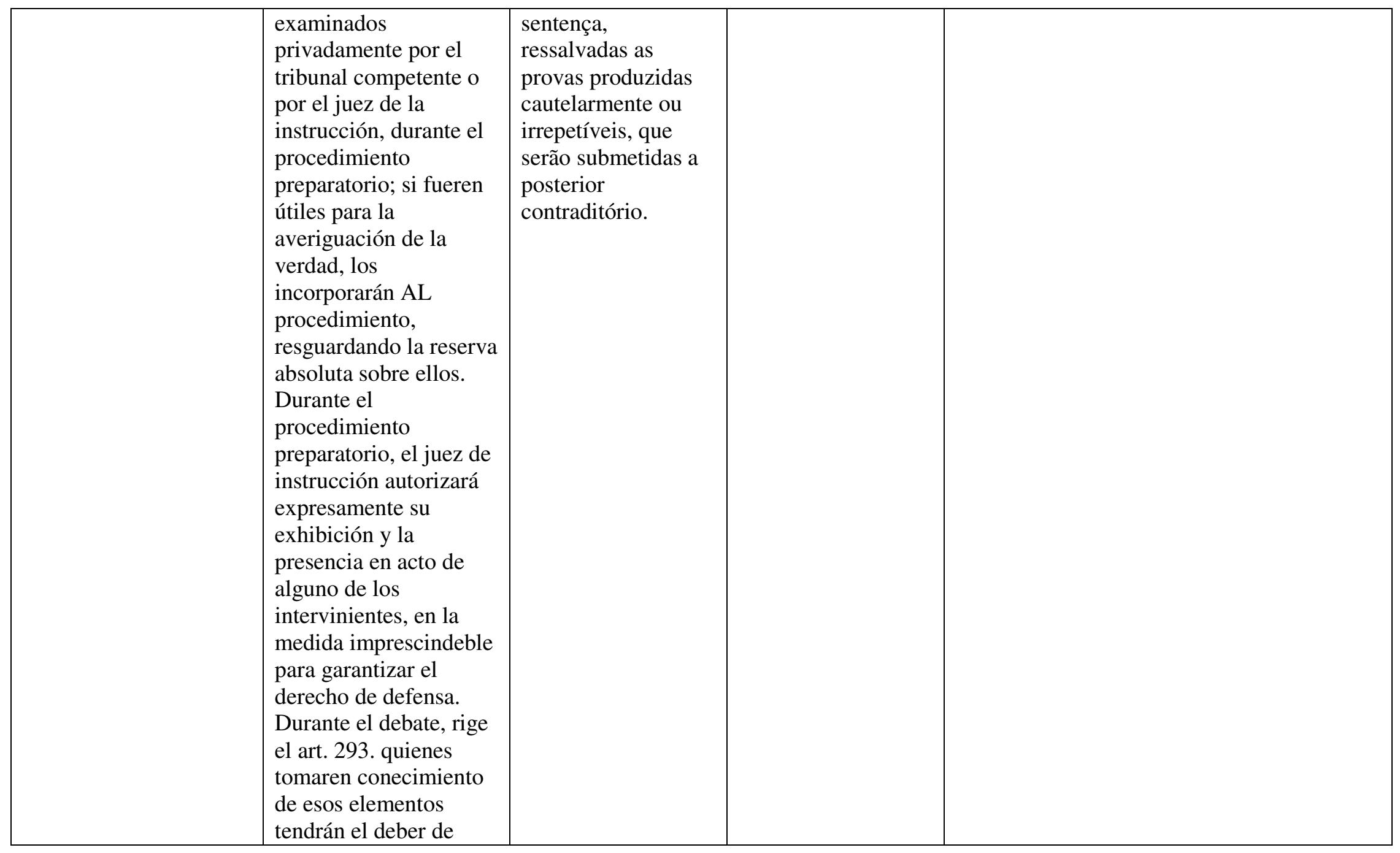




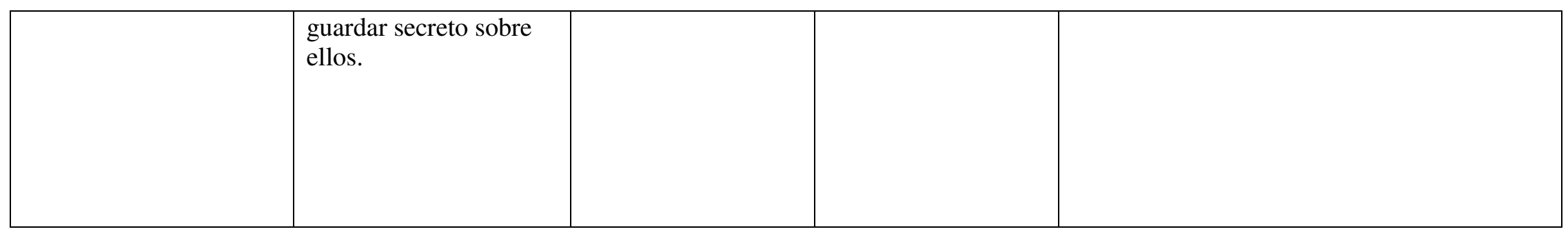

